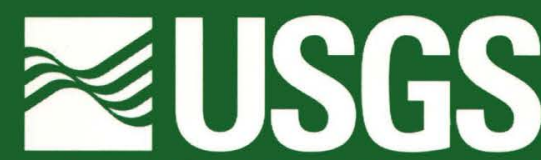

\title{
Results of Water-Quality Sampling and Ecological Characterization of Streams of Congaree Swamp, South Carolina 1995-98
}

\author{
U.S. Geological Survey \\ Water-Resources Investigations Report 99-4121
}

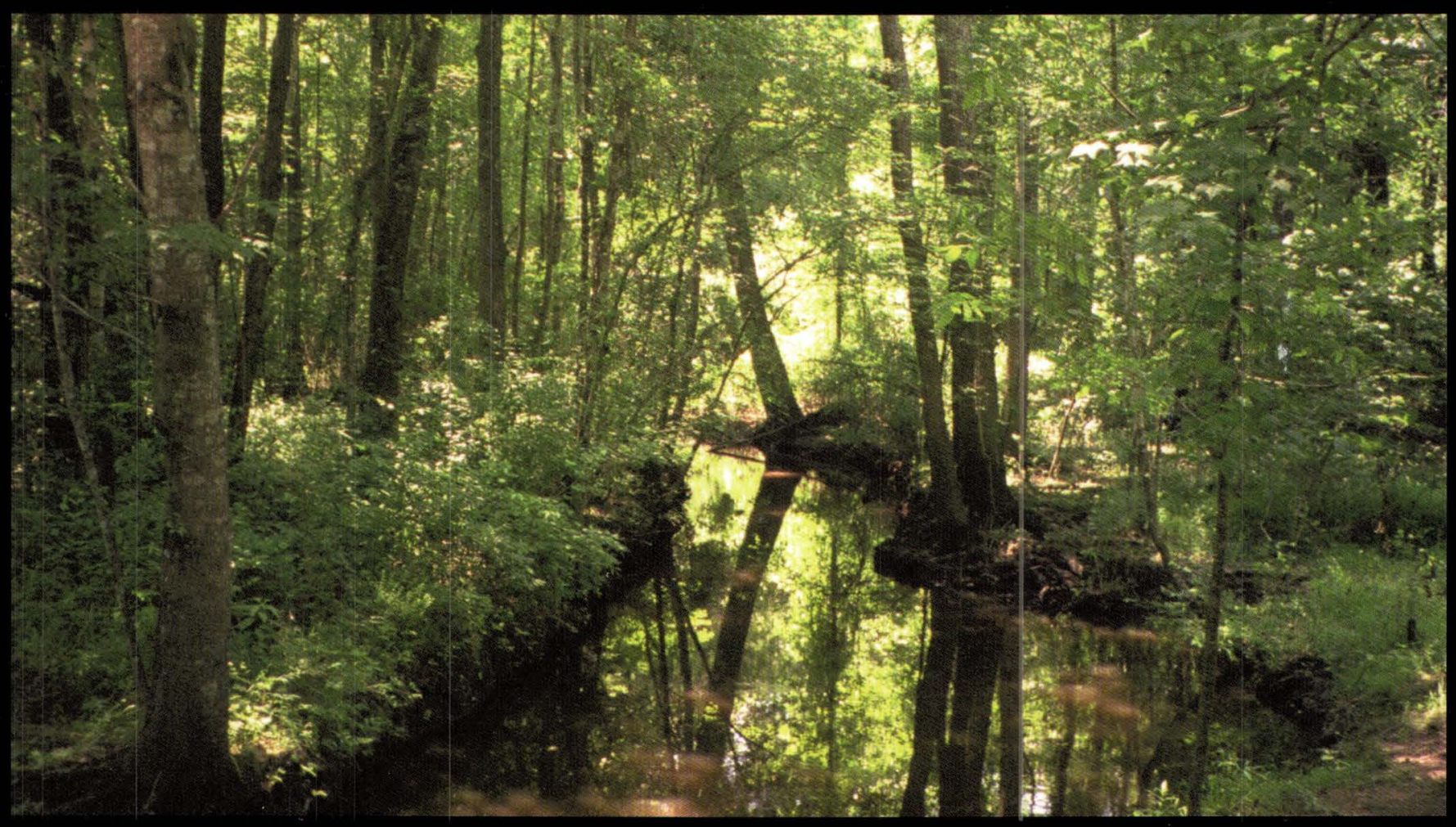


Cover photograph: Cedar Creek, South Carolina, taken by Lance Wilhelm, U.S. Geological Survey. 


\section{Results of Water-Quality Sampling and Ecological Characterization of Streams of Congaree Swamp, South Carolina, 1995-98}

By Terry L. Maluk and Thomas A. Abrahamsen

U.S. GEOLOGICAL SURVEY

Water-Resources Investigations Report 99-4121

Prepared as part of the

NATIONAL WATER-QUALITY ASSESSMENT PROGRAM

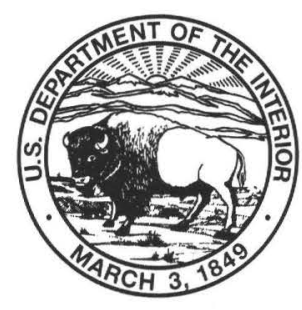

Columbia, South Carolina 1999 


\title{
U.S. DEPARTMENT OF THE INTERIOR \\ BRUCE BABBITT, Secretary
}

\author{
U.S. GEOLOGICAL SURVEY
}

Charles G. Groat, Director

The use of firm, trade, and brand names in this report is for identification purposes only and does not constitute endorsement by the U.S. Government.

For additional information write to:

District Chief

U.S. Geological Survey

Stephenson Center, Suite 129

720 Gracern Road

Columbia, South Carolina 29210-7651
Copies of this report can be purchased from:

U.S. Geological Survey

Branch of Information Services

Denver Federal Center, Box 25286

Denver, Colorado 80225-0286 


\section{FOREWORD}

The mission of the U.S. Geological Survey (USGS) is to assess the quantity and quality of the earth resources of the Nation and to provide information that will assist resource managers and policymakers at Federal, State, and local levels in making sound decisions. Assessment of water-quality conditions and trends is an important part of this overall mission.

One of the greatest challenges faced by waterresources scientists is acquiring reliable information that will guide the use and protection of the Nation's water resources. That challenge is being addressed by Federal, State, interstate, and local water-resource agencies and by many academic institutions. These organizations are collecting water-quality data for a host of purposes that include: compliance with permits and water-supply standards; development of remediation plans for a specific contamination problem; operational decisions on industrial, wastewater, or water-supply facilities; and research on factors that affect water quality. An additional need for water-quality information is to provide a basis on which regional and national-level policy decisions can be based. Wise decisions must be based on sound information. As a society we need to know whether certain types of water-quality problems are isolated or ubiquitous, whether there are significant differences in conditions among regions, whether the conditions are changing over time, and why these conditions change from place to place and over time. The information can be used to help determine the efficacy of existing water-quality policies and to help analysts determine the need for and likely consequences of new policies.

To address these needs, the Congress appropriated funds in 1986 for the USGS to begin a pilot program in seven project areas to develop and refine the National Water-Quality Assessment (NAWQA) Program. In 1991, the USGS began full implementation of the program. The NAWQA Program builds upon an existing base of water-quality studies of the USGS, as well as those of other Federal, State, and local agencies. The objectives of the NAWQA Program are to:

- Describe current water-quality conditions for a large part of the Nation's freshwater streams, rivers, and aquifers.
- Describe how water quality is changing over time.

- Improve understanding of the primary natural and human factors that affect water-quality conditions.

This information will help support the development and evaluation of management, regulatory, and monitoring decisions by other Federal, State, and local agencies to protect, use, and enhance water resources.

The goals of the NAWQA Program are being achieved through ongoing and proposed investigations of 60 of the Nation's most important river basins and aquifer systems, which are referred to as study units. These study units are distributed throughout the Nation and cover a diversity of hydrogeologic settings. More than two-thirds of the Nation's freshwater use occurs within the 60 study units and more than twothirds of the people served by public water-supply systems live within their boundaries.

National synthesis of data analysis, based on aggregation of comparable information obtained from the study units, is a major component of the program. This effort focuses on selected water-quality topics using nationally consistent information. Comparative studies will explain differences and similarities in observed water-quality conditions among study areas and will identify changes and trends and their causes. The first topics addressed by the national synthesis are pesticides, nutrients, volatile organic compounds, and aquatic biology. Discussions on these and other waterquality topics will be published in periodic summaries of the quality of the Nation's ground and surface water as the information becomes available.

This report is an element of the comprehensive body of information developed as part of the NAWQA Program. The program depends heavily on the advice, cooperation, and information from many Federal, State, interstate, Tribal, and local agencies and the public. The assistance and suggestions of all are greatly appreciated.

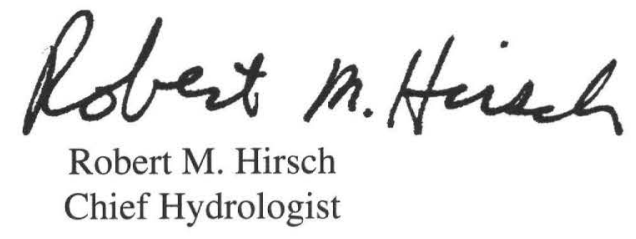





\section{CONTENTS}

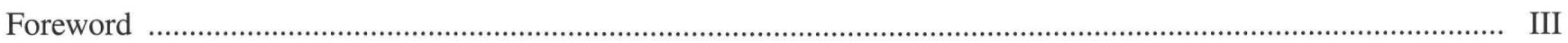

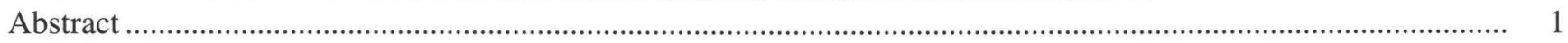

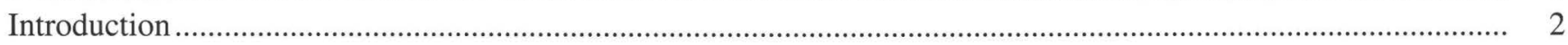

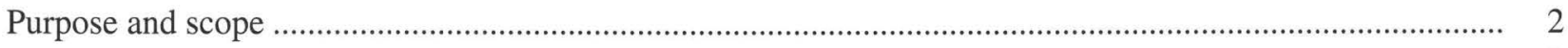

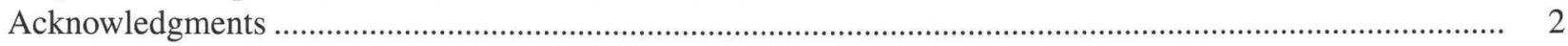

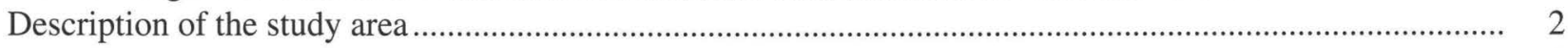

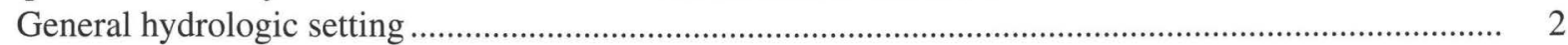

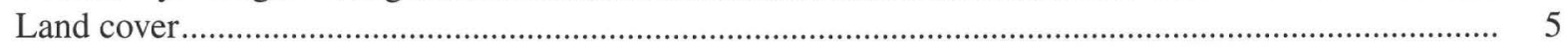

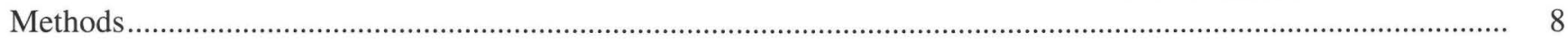

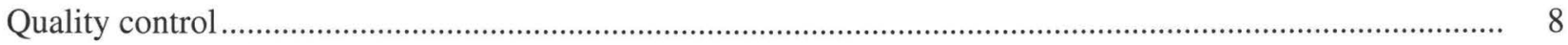

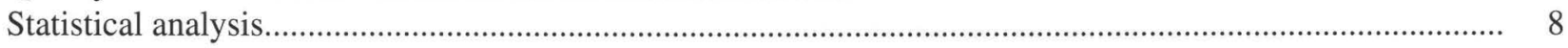

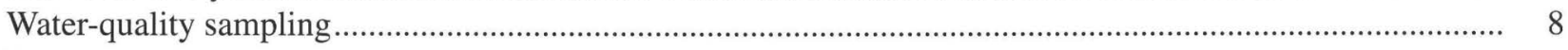

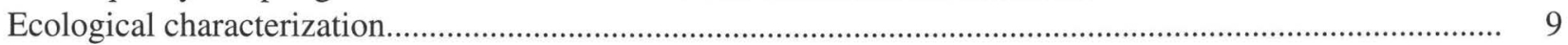

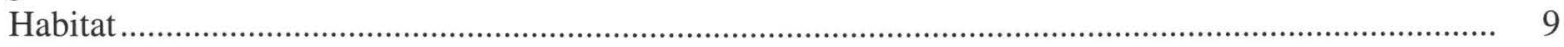

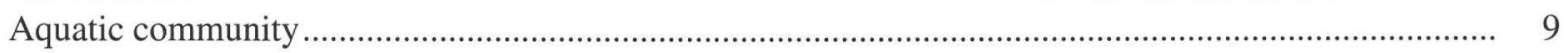

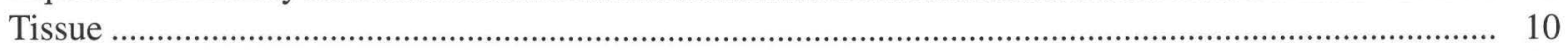

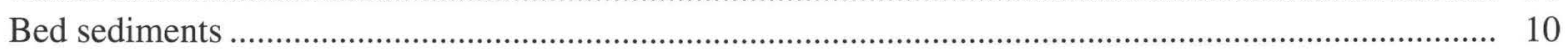

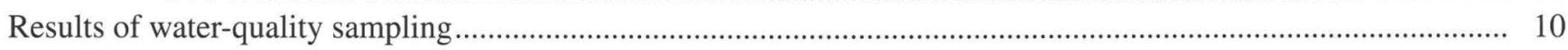

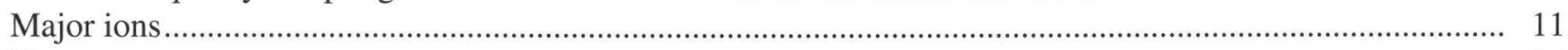

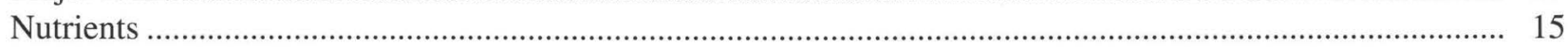

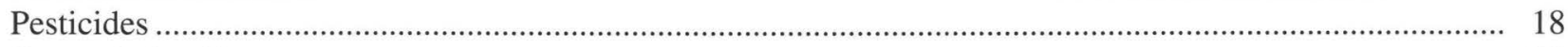

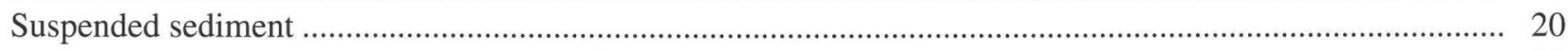

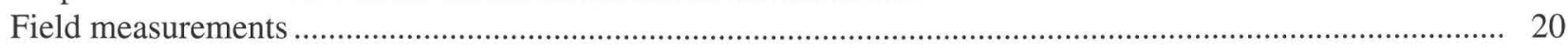

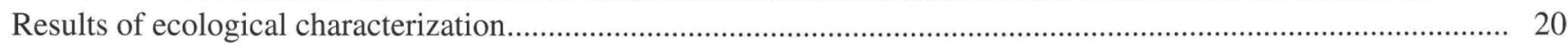

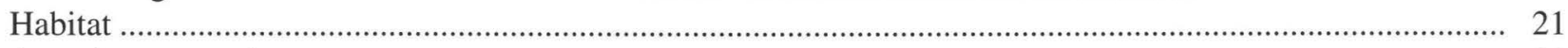

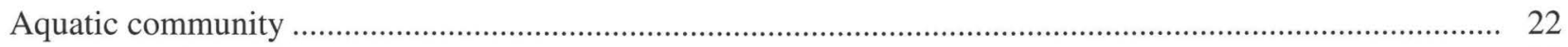

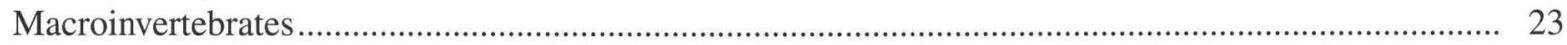

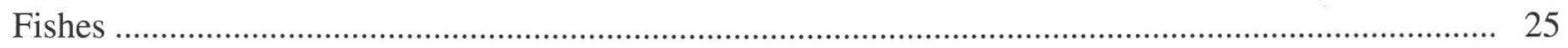

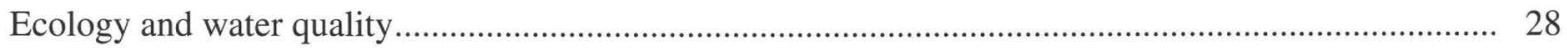

Tissue

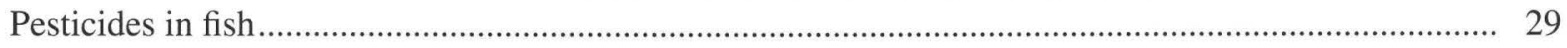

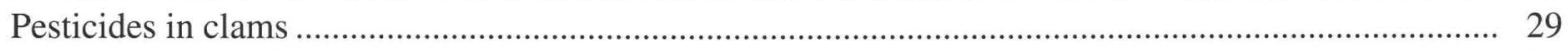

Trace and major elements in fish ....................................................................................... 30

Trace and major elements in clams ............................................................................................ 30

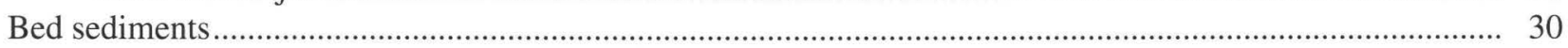

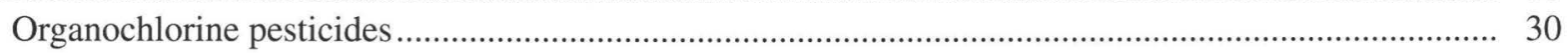

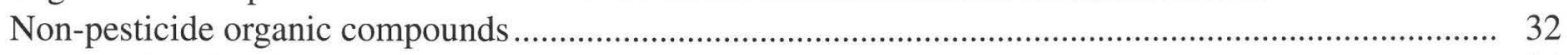

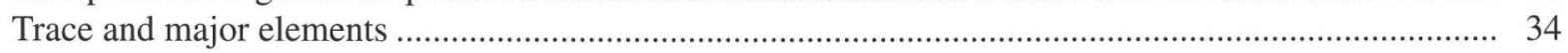

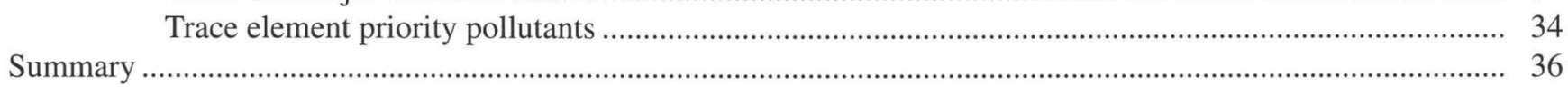

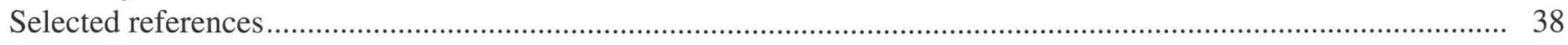

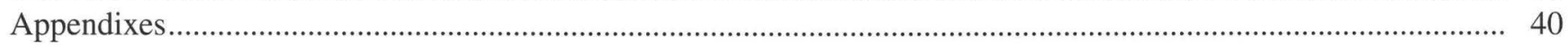


1-3. Maps showing:

1. Location of the Congaree Swamp study area within the Santee River Basin and coastal drainages study area, North and South Carolina.

2. Location of Congaree Swamp National Monument and study area basin boundaries, South Carolina.

3. Land cover and location of sampling site in the Congaree River at Highway 601 Basin, North and South Carolina.....

4. Land cover and location of sampling sites in the Myers Creek, Cedar Creek, Cedar Creek near Wise Lake, and Toms Creek Basins, South Carolina

5-11. Graphs showing statistical distribution of:

5. Calcium, magnesium, sodium, and potassium in streams of Congaree Swamp ............................. 12

6. Silica, chloride, fluoride, and sulfate in streams of Congaree Swamp ........................................ 13

7. Iron and manganese in streams of Congaree Swamp.................................................................

8. Nitrogen species in streams of Congaree Swamp ...................................................................... 16

9. Phosphorus species in streams of Congaree Swamp................................................................ 17

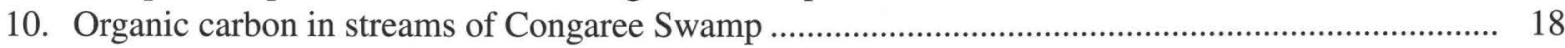

11. Suspended sediment in streams of Congaree Swamp ................................................................... 21

12-20. Graphs showing:

12. Number of distinct macroinvertebrate taxa identified in streams of Congaree Swamp .................. 23

13. Macroinvertebrate density in streams of Congaree Swamp ............................................................ 24

14. Fish species diversity and catch per unit effort in streams of Congaree Swamp ............................. 27

15. $p, p^{\prime}-\mathrm{DDE}$ detected in fish tissue collected in streams of Congaree Swamp ................................... 29

16. DDT and metabolites detected in bed sediments of streams of Congaree Swamp .......................... 31

17. Summation of non-pesticide organic compounds detected in bed sediments of streams of Congaree Swamp

18. Selected non-pesticide organic compounds in bed sediments of streams of Congaree Swamp

19. Trace element priority pollutants in bed sediments of streams of Congaree Swamp ...................... 34

20. Trace element priority pollutants in clams and bed sediments of Cedar Creek................................. 36

\section{TABLES}

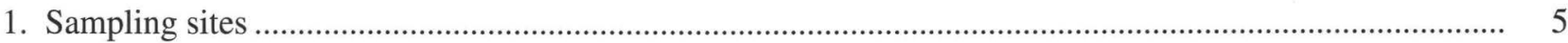

2. Ranges in major ion concentrations in streams of Congaree Swamp ............................................. 11

3. Ranges in nutrient concentrations in streams of Congaree Swamp ......................................................... 15

4. Summary of pesticides detected in streams of Congaree Swamp ............................................................... 19

5. Numbers of pesticide detections in streams of Congaree Swamp .......................................................... 20

6. Habitat characteristics of streams in Congaree Swamp ......................................................................... 22

7. Riparian zone dominant tree species and population percentages .............................................................. 23

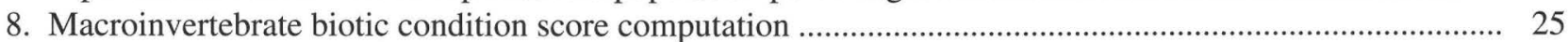

9. Fish species identified in streams of Congaree Swamp ........................................................................ 26

10. Fish indices of biotic integrity (IBI) in streams of Congaree Swamp........................................................ 28

11. Bed-sediment organochlorine pesticides.................................................................................. 31

12. Semivolatile organic compounds in Myers Creek bed sediments compared to the national data base ......... 33

13. Trace element priority pollutant concentrations in bed sediments of streams of Congaree Swamp and Canadian threshold effect levels for the protection of aquatic life 


\section{APPENDIXES}

1. Major ion concentrations in streams of Congaree Swamp................................................................

2. Nutrient concentrations in streams of Congaree Swamp .......................................................................... 44

3. Parameter codes and method detection limits for pesticides analyzed in samples from streams of Congaree Swamp

4. Pesticide concentrations in streams of Congaree Swamp ....................................................................... 48

5. Suspended sediment in streams of Congaree Swamp ........................................................................ 50

6. Field-measured constituents in streams of Congaree Swamp............................................................... 52

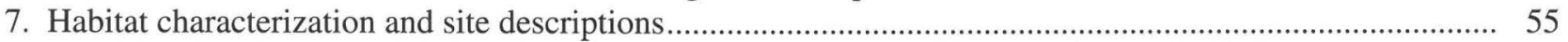

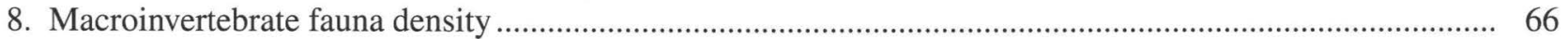

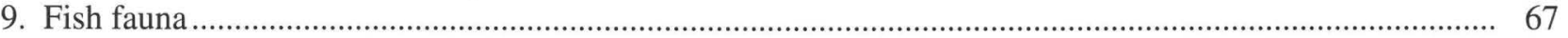

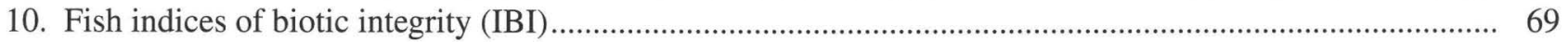

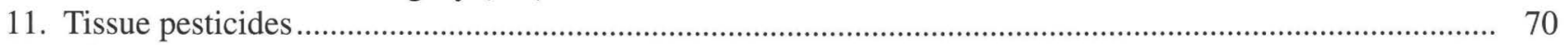

12. Elements in carp liver tissue from the Congaree River at Columbia ........................................................... 71

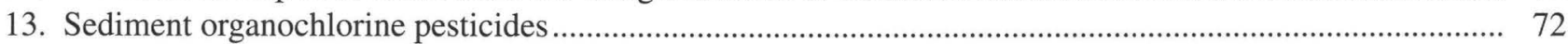

14. Sediment non-pesticide organic compounds ..................................................................................... 73

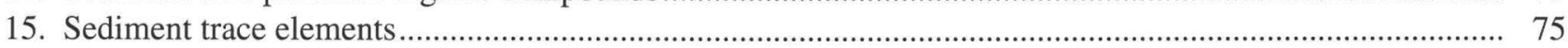

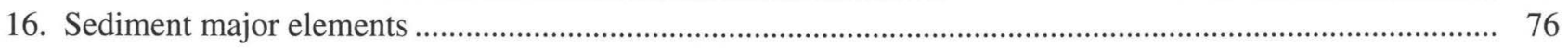


CONVERSION FACTORS, TEMPERATURE, WATER-QUALITY UNITS, AND ACRONYMS:

\begin{tabular}{rll}
\hline \multicolumn{1}{c}{ Multiply } & \multicolumn{1}{c}{ By } & \multicolumn{1}{c}{ To obtain } \\
\hline millimeter $(\mathrm{mm})$ & 0.03937 & inch \\
meter $(\mathrm{m})$ & 3.281 & foot \\
kilogram $(\mathrm{kg})$ & 2.205 & pound \\
cubic feet per second $\left(\mathrm{ft}^{3} / \mathrm{s}\right)$ & 0.02832 & cubic meter per second \\
kilometer $\left(\mathrm{km}^{2}\right)$ & 0.6214 & mile \\
square kilometer $\left(\mathrm{km}^{2}\right)$ & 0.3861 & square mile \\
\hline
\end{tabular}

Temperature in degrees Celsius $\left({ }^{\circ} \mathrm{C}\right)$ can be converted to degrees Fahrenheit as follows:

$$
{ }^{\circ} \mathrm{F}=\left({ }^{\circ} \mathrm{C} \times 1.8\right)+32
$$

\section{ABBREVIATED WATER-QUALITY UNITS:}

$\mathrm{mg} / \mathrm{L}$

$\mu \mathrm{g} / \mathrm{L}$

$\mathrm{g} / \mathrm{kg}$

$\mu \mathrm{g} / \mathrm{g}$

$\mu \mathrm{g} / \mathrm{kg}$

$\mu \mathrm{m}$

CUE

IBI

MDL

MRL

NAWQA

NPDES

NPS

NWQL

$\mathrm{PAH}$

RTH

SANT

SCDHEC

STORET

TEL

U.S. EPA

USGS milligram per liter

microgram per liter

gram per kilogram

microgram per gram

microgram per kilogram

micrometer

$\mathrm{mm}$
$\mathrm{cm}$
$\mathrm{mm}$
$\mathrm{su} / \mathrm{cm}$

millimeter

centimeter

meter

kilometer

standard unit

microsiemens per centimeter

\section{ACRONYMS:}

Catch per unit of effort

Index of biotic integrity

Method detection limit

Minimum reporting level

National Water-Quality Assessment Program

National Pollutant Discharge Elimination System

National Park Service

National Water Quality Laboratory

Polycyclic aromatic hydrocarbon

Richest targeted habitat

Santee River Basin and coastal drainages

South Carolina Department of Health and Environmental Control

Storage and Retrieval

Threshold effect level

U.S. Environmental Protection Agency

U.S. Geological Survey 


\title{
Results of Water-Quality Sampling and Ecological Characterization of Streams of Congaree Swamp, South Carolina, 1995-98
}

\author{
By Terry L. Maluk and Thomas A. Abrahamsen
}

\section{ABSTRACT}

Between October 1995 and September 1998, water-quality samples were collected at five sites in streams of Congaree Swamp, South Carolina, as part of the U.S. Geological Survey National Water-Quality Assessment Program. Water-quality samples were collected at one site on the Congaree River (at Columbia), Myers Creek, two sites on Cedar Creek (Cedar Creek and Cedar Creek near Wise Lake), and Toms Creek. Samples were analyzed for major ions, nutrients, pesticides, and suspended sediments.

Bed-sediment and tissue samples were collected at six sites in streams of Congaree Swamp and analyzed for 21 organochlorine pesticides and 43 major and trace elements. In addition to the five sites sampled for water quality, a second site on the Congaree River (at Highway 601) was sampled for bed sediment and tissue. Sixty-seven non-pesticide organic compounds were analyzed in sediment samples only. Aquatic community structure in each stream was characterized through qualitative and semiquantitative collections of algae, macroinvertebrates, and fish. Habitat data and riparian zone tree data also were collected at four sites as part of the stream characterization.

Though most major ion concentrations were highest in the Congaree River at Columbia, iron and manganese concentrations were lower in the Congaree River at Columbia than in the other streams. Secondary drinking-water standards for iron (300 micrograms per liter) and manganese (50 micrograms per liter) were exceeded in at least one sample at each site. Nitrogen and phosphorus concentrations were low. Nitrite-plus-nitrate nitrogen concentrations were significantly higher in the Congaree River at Columbia; however, all concentrations were below 0.5 milligram per liter. Organic carbon concentrations generally were lowest in the Congaree River at Columbia. Twelve different pesticides were detected in samples from the five surface-water-quality sampling sites; tebuthiuron and atrazine were the most frequently detected pesticides. The Congaree River at Columbia had the highest number of different pesticides detected (9), and Cedar Creek had the lowest (5). Suspended-sediment concentrations were highest in the Congaree River at Columbia. Specific conductance, alkalinity, and $\mathrm{pH}$ were significantly higher in the Congaree River at Columbia than in the other streams.

Analyses of the structure of the macroinvertebrate communities of the streams, through qualitative and semi-quantitative collections, indicated that the water quality of Cedar Creek near Wise Lake was slightly impaired when compared with a reference stream. The water quality in Myers Creek, Cedar Creek, and Toms Creek was non-impaired when compared with the same reference stream. Fish fauna community analysis indicated that Cedar Creek water quality can be classified as "fair" in terms of an index of biotic integrity. Water quality in the Congaree River at Columbia, Myers Creek, Cedar 
Creek near Wise Lake, and Toms Creek is classified as "poor," based on fish indices of biotic integrity.

Organochlorine pesticides, non-pesticide organic compounds, and trace and major elements in bed sediments had no discernible detrimental effect on the aquatic communities in any of the streams. Pesticides and major ion concentrations detected in the water column had no discernible detrimental effect on the aquatic communities.

Habitat structure, dissolved oxygen, and water temperature were the most important properties affecting species distribution and density of the macroinvertebrate community. No chemical product or by-product of land-use activities appeared to have detrimental effects on fish or macroinvertebrate community structure.

\section{INTRODUCTION}

As part of the National Water-Quality Assessment (NAWQA) Program, the U.S. Geological Survey (USGS) conducted a study of several streams of Congaree Swamp in South Carolina from October 1995 through September 1998. The study was a cooperative effort between the USGS and the National Park Service (NPS) to investigate the status of and trends in general water quality and to conduct an ecological characterization of three tributary streams to the Congaree Swamp National Monument (Myers, Cedar, and Toms Creeks), and the Congaree River that borders the Monument.

\section{Purpose and Scope}

This report presents results of a water-quality study and ecological characterization of selected streams of Congaree Swamp near Columbia, South Carolina. Six sites were sampled on four stream systems: three tributaries that flow into Congaree Swamp National Monument (Myers, Cedar, and Toms Creeks), one stream within the Monument (Cedar Creek near Wise Lake), and two sites on the Congaree River. Sampling consisted of monthly or quarterly water-quality analyses of major ions, nutrients, organic carbon, pesticides, and suspended sediment. Algae, macroinvertebrates, and fishes were collected in each stream to assess aquatic community structure. Bed- sediment and tissue samples were analyzed for selected organic compounds, major elements, and trace elements. Habitat was assessed at Myers Creek, the two Cedar Creek sites, and Toms Creek.

\section{Acknowledgments}

Appreciation is extended to the National Park Service, which provided partial funding for the Congaree Swamp study. The authors wish to thank the NAWQA team members who assisted with sampling, and the report team for their time spent reviewing and improving the quality of this report.

\section{Description of the Study Area}

The study area is located within the NAWQA Santee River Basin and coastal drainages study area along the Congaree River in South Carolina (fig. 1). The Congaree Swamp National Monument is located about 32 kilometers $(\mathrm{km})$ southeast of Columbia, South Carolina (fig. 2). The Monument includes one of the last large stands of old-growth bottomland hardwood forest in South Carolina and contains about 90 species of trees (National Park Service, 1999). Water-quality and ecological samples were collected in the Congaree River at Columbia approximately $40 \mathrm{~km}$ upstream from Congaree Swamp National Monument; Myers Creek on State Road 734 at the Monument boundary; Cedar Creek on State Road 734 at the Monument boundary; Cedar Creek near Wise Lake within the Monument; and Toms Creek below State Road 489 (table 1). Additional sediment and tissue samples were collected in the Congaree River at Highway 601 approximately $3 \mathrm{~km}$ downstream of the Monument boundary.

\section{General Hydrologic Setting}

The Congaree River flows along the southern edge of the Monument boundary. Tributaries that flow through the Monument toward the Congaree River are blackwater streams and include Cedar Creek, Myers Creek, and Toms Creek. The basins of the tributaries are in the Upper Coastal Plain region (fig. 2). During low streamflow periods, the tributaries are supplied by seepage from ground water. During floods, water is transported from the Congaree River across the flood plain toward the tributaries (Patterson and others, 1985). 


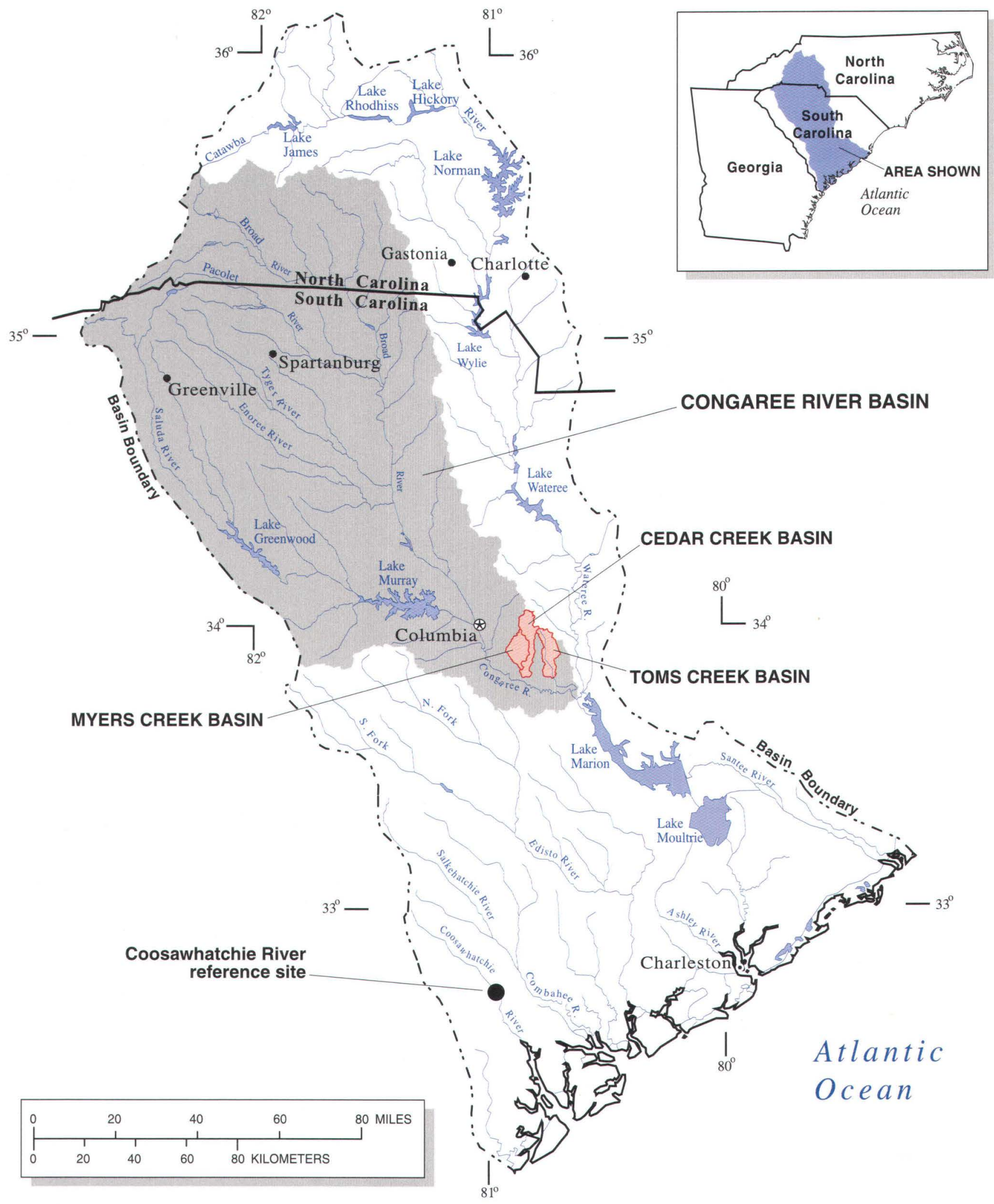

Figure 1. Location of the Congaree Swamp study area within the Santee River Basin and coastal drainages study area, North and South Carolina. 

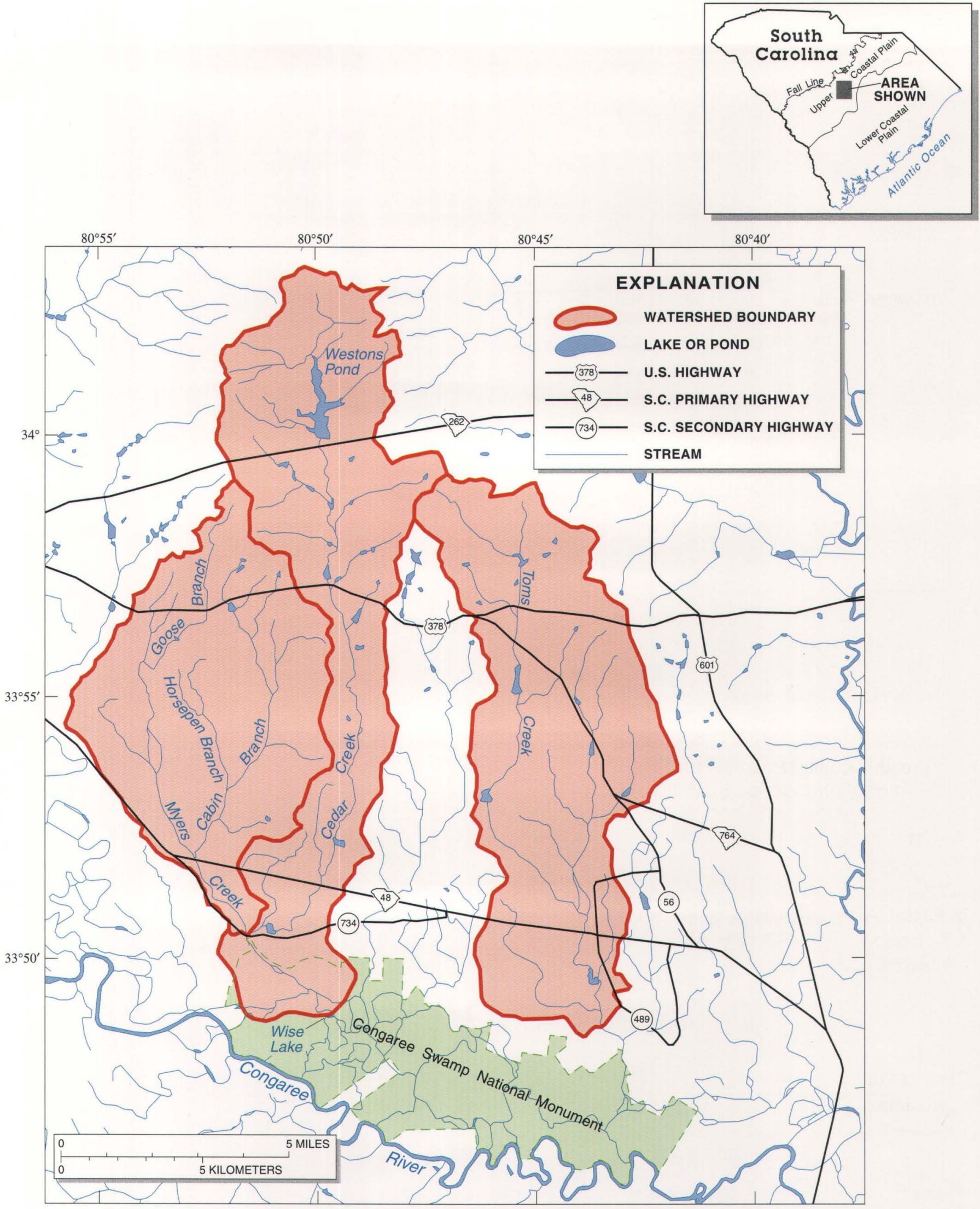

Figure 2. Location of Congaree Swamp National Monument and study area basin boundaries, South Carolina. 
Table 1. Sampling sites

\begin{tabular}{|c|c|c|c|c|c|c|c|c|c|}
\hline $\begin{array}{l}\text { USGS } \\
\text { down- } \\
\text { stream } \\
\text { order } \\
\text { number }\end{array}$ & $\begin{array}{c}\text { USGS } \\
\text { station name }\end{array}$ & $\begin{array}{l}\text { Short } \\
\text { name }\end{array}$ & Latitude & Longitude & $\begin{array}{l}\text { Water } \\
\text { quality }\end{array}$ & $\begin{array}{c}\text { Bed } \\
\text { sediment }\end{array}$ & Tissue & $\begin{array}{c}\text { Com- } \\
\text { munity } \\
\text { structure }\end{array}$ & Habitat \\
\hline 02169500 & $\begin{array}{c}\text { Congaree River at } \\
\text { Columbia, S.C. }\end{array}$ & $\begin{array}{l}\text { Congaree } \\
\text { River at } \\
\text { Columbia }\end{array}$ & $33^{\circ} 59^{\prime} 35^{\prime \prime}$ & $81^{\circ} 03^{\prime} 00^{\prime \prime}$ & $x$ & $x$ & $x$ & $x$ & \\
\hline 02169660 & $\begin{array}{c}\text { Myers Creek at } \\
\text { S-40-734 near } \\
\text { Hopkins, S.C. }\end{array}$ & Myers Creek & $33^{\circ} 51^{\prime} 25^{\prime \prime}$ & $80^{\circ} 49^{\prime} 48^{\prime \prime}$ & $x$ & $x$ & $x$ & $x$ & $x$ \\
\hline 02169670 & $\begin{array}{l}\text { Cedar Creek } \\
\text { below Myers } \\
\text { Creek near } \\
\text { Hopkins, S.C. }\end{array}$ & Cedar Creek & $33^{\circ} 50^{\prime} 23^{\prime \prime}$ & $80^{\circ} 51^{\prime} 38^{\prime \prime}$ & $x$ & $x$ & $x$ & $x$ & $x$ \\
\hline 02169672 & $\begin{array}{l}\text { Cedar Creek at } \\
\text { Cedar Creek } \\
\text { Hunt Club near } \\
\text { Gadsden, S.C. }\end{array}$ & $\begin{array}{l}\text { Cedar Creek } \\
\text { near Wise } \\
\text { Lake }\end{array}$ & $33^{\circ} 48^{\prime} 58^{\prime \prime}$ & $80^{\circ} 49^{\prime} 39^{\prime \prime}$ & $x$ & $x$ & $x$ & $x$ & $x$ \\
\hline 021696966 & $\begin{array}{l}\text { Toms Creek below } \\
\text { S-40-489 near } \\
\text { Gadsden, S.C. }\end{array}$ & Toms Creek & $33^{\circ} 48^{\prime} 41^{\prime \prime}$ & $80^{\circ} 43^{\prime} 30^{\prime \prime}$ & $x$ & $x$ & $x$ & $x$ & $x$ \\
\hline 02169750 & $\begin{array}{l}\text { Congaree River } \\
\text { near Fort Motte, } \\
\text { S.C. }\end{array}$ & $\begin{array}{l}\text { Congaree } \\
\text { River at } \\
\text { Highway } 601\end{array}$ & $33^{\circ} 45^{\prime} 07^{\prime \prime}$ & $80^{\circ} 38^{\prime} 45^{\prime \prime}$ & & $x$ & $x$ & & \\
\hline
\end{tabular}

The climate in central South Carolina includes mild winters and very hot summers. Average monthly temperatures for the years 1961-90 ranged from 6.4 degrees Celsius $\left({ }^{\circ} \mathrm{C}\right.$ ) in January to $27.2{ }^{\circ} \mathrm{C}$ in July (South Carolina Department of Natural Resources, 1998). During 1961-90, the maximum monthly temperature in July was $33.2^{\circ} \mathrm{C}$, with daily highs more than $37.8^{\circ} \mathrm{C}$. Annual rainfall in Columbia is about 127 centimeters $(\mathrm{cm})$ per year. Average monthly rainfall ranges from $7.4 \mathrm{~cm}$ in November to $15.4 \mathrm{~cm}$ in August. Average annual snowfall in Columbia is $5.3 \mathrm{~cm}$ per year (South Carolina Department of Natural Resources, 1998).

\section{Land Cover}

Land cover in the basin above the Congaree River at Columbia sampling site consists of approximately 70 percent mixed forests, 20 percent agriculture, 5 percent urban, 3 percent water and wetlands, and the remaining 2 percent barren land (fig. 3). The drainage area of the Congaree River at
Columbia, formed at the confluence of the Saluda and Broad Rivers, is approximately 20,300 square kilometers $\left(\mathrm{km}^{2}\right.$; Cooney and others, 1998). The large urban areas in the basin are Columbia and GreenvilleSpartanburg, S.C. Many industrial and municipal sources discharge treated wastewater into the Congaree River Basin (South Carolina Department of Health and Environmental Control, 1995).

Land cover in the Myers Creek Basin is approximately 48 percent forested with a mix of evergreen and deciduous forests, 33 percent agriculture, 15 percent wetlands or open water, and 4 percent urban (fig. 4). The drainage area of the basin is about $83 \mathrm{~km}^{2}$. Several tributaries join Myers Creek-Goose Branch, Horsepen Branch, and Cabin Branch. These tributaries receive wastewater from several domestic and industrial sources (South Carolina Department of Health and Environmental Control, 1995). Myers Creek joins Cedar Creek at the northwest boundary of the Monument (fig. 4). 

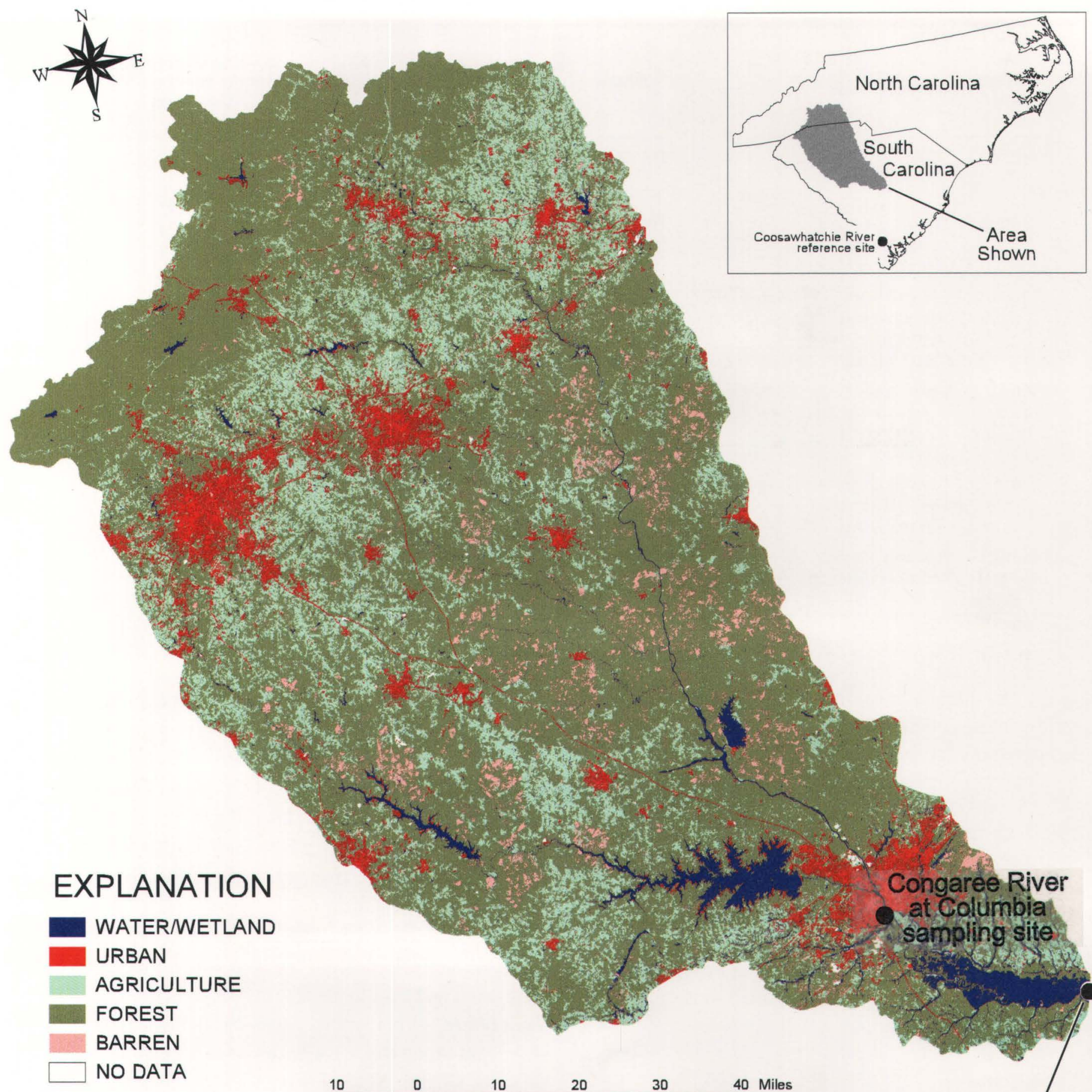

\section{EXPLANATION}

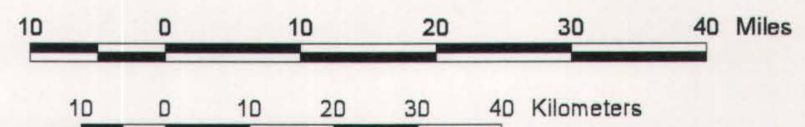

Congaree River at Highway 601 sampling site

Figure 3. Land cover and location of sampling site in the Congaree River at Highway 601 Basin, North and South Carolina. 


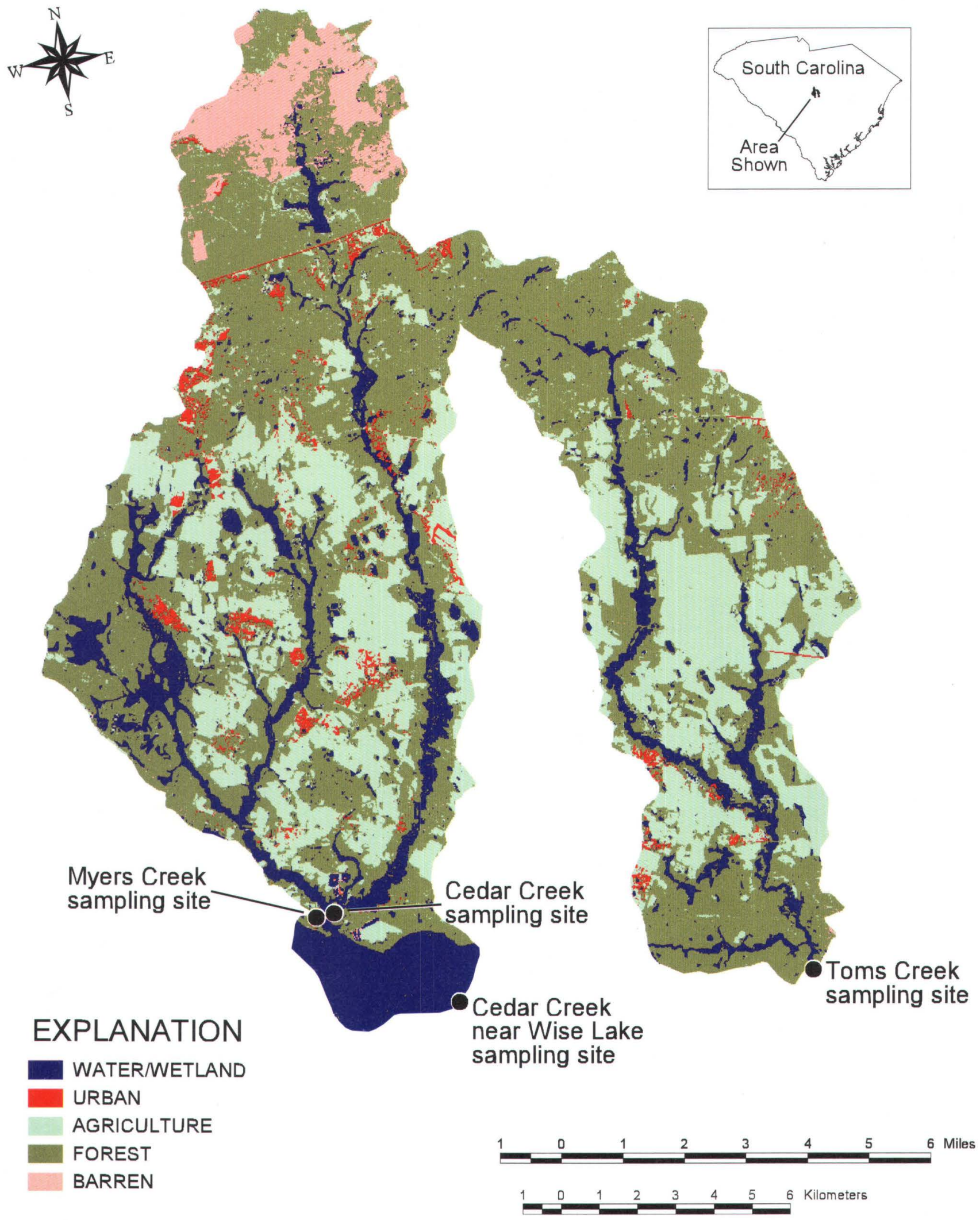

Figure 4. Land cover and location of sampling sites in the Myers Creek, Cedar Creek, Cedar Creek near Wise Lake, and Toms Creek Basins, South Carolina. 
Land cover in the Cedar Creek Basin is approximately 58 percent forested with a mix of evergreens and deciduous hardwoods, 18 percent agriculture, and 8 percent wetlands in the lower part of the basin. Commercial and urban areas represent 2 percent of the basin, 12 percent of the basin is barren or in transition, and 2 percent consists of ponds along the length of Cedar Creek (fig. 4). The drainage area of the Cedar Creek Basin above the Monument is about $90 \mathrm{~km}^{2}$. Two military bases are in the Cedar Creek Basin. Cedar Creek receives wastewater from several minor domestic sources and two minor industrial wastewater sources. Downstream from the confluence with Myers Creek, the total basin area of Cedar Creek near Wise Lake within the Monument is about $184 \mathrm{~km}^{2}$.

Land cover in the Toms Creek Basin is approximately 56 percent forested, 10 percent wetlands or open water, 33 percent agriculture, and less than 1 percent each urban and barren lands (fig. 4). Toms Creek enters the northeast corner of the Monument and has a basin drainage area of about $100 \mathrm{~km}^{2}$.

\section{METHODS}

Water-quality and ecological data were collected for this study in accordance with methods required by the NAWQA Program. NAWQA methods and protocols are available on the World Wide Web (U.S. Geological Survey, 1999b).

\section{Quality Control}

Field-blank samples were collected using certified water with undetectable concentrations of constituents being analyzed. Blank samples were analyzed for major ions, nutrients, organic carbon, and pesticides to assess possible cross contamination introduced during sample collection, processing, shipment, or laboratory analysis (Shelton, 1994). Fish identification was verified by Mr. Fritz Rohde, North Carolina Department of Marine Fisheries, Wilmington, N.C.

\section{Statistical Analysis}

Surface-water data were tested for correlations using the nonparametric Kendall's tau correlation coefficient and an acceptable error rate of 0.01 $(\alpha=0.01$; Helsel and Hirsch, 1995). Significant differences in constituent concentrations between stations were tested using Tukey's test in an analysis of variance on the rank-transformed data ( $\alpha=0.05)$. Bed-sediment and tissue data were tested for normal distribution using the Shapiro-Wilkes test. If normally distributed, the data were analyzed using a one-way analysis of variance with Tukey's pair-wise comparison to determine if streams were significantly different. If data were not normally distributed, analyses were conducted using a Kruskal-Wallis oneway analysis of variance. Statistical analyses of bedsediment and tissue results were conducted using an acceptable error level of 0.05 . Correlations of waterquality constituents with macroinvertebrate community diversity also were investigated using an acceptable error rate of 0.05 .

\section{Water-Quality Sampling}

Surface-water samples were collected and processed according to guidelines specified by Shelton (1994). Streamflow generally was great enough to allow multiple vertical sections (3-20) to be sampled using a depth-integrated sampler. Samples were analyzed for major ions, nutrients, organic carbon, and pesticides at the USGS National Water Quality Laboratory (NWQL). Suspended-sediment samples were analyzed by the Kentucky District sediment laboratory. Specific conductance, stream temperature, $\mathrm{pH}$, dissolved-oxygen concentration and percent saturation, and alkalinity were measured onsite.

Teflon sampling equipment (bottle, nozzle, and collar) was used to ensure sample integrity. A Teflon cone splitter was used to composite and split the samples into separate sample bottles for various analyses. Suspended-sediment sample bottles were filled directly from the cone splitter. After splitting, samples for dissolved major ions and dissolved nutrients were filtered immediately using a 0.45 -micrometer $(\mu \mathrm{m})$ pore size filter that was prerinsed with deionized water and stream water. Samples for dissolved major ions were preserved with nitric 
acid. Samples for dissolved pesticides were filtered immediately using a $0.7-\mu \mathrm{m}$ pore size glass-fiber filter. Samples for suspended and dissolved organic carbon were collected from the centroid of flow using a baked glass bottle, and these samples were filtered using a $0.45-\mu \mathrm{m}$ silver filter. The filtrate was collected for dissolved organic carbon analysis, and the filters were analyzed for suspended organic carbon.

All samples were chilled immediately after filtration and preserved for overnight transport to the NWQL in Denver, Colo. Samples were analyzed using NAWQA methods described in Patton and Truitt (1992), Fishman (1993), Zaugg and others (1995), and Werner and others (1996).

Method detection limit (MDL) is "the minimum concentration of a substance that can be identified, measured, and reported with 99-percent confidence that the analyte concentration is greater than zero, determined from the analysis of a sample in a given matrix containing the analyte" (U.S. Geological Survey, 1999a). At the MDL concentration, the risk of a false positive is predicted to be no more than 1 percent. Analytical uncertainty and many different possibilities for error are reflected in MDL's (Clark and Whitfield, 1994). Pesticides are listed in this report with MDL's from the NWQL. The NWQL reports all analytical concentrations if all quality-control and methods criteria are met. Pesticides that are positively identified at concentrations less than the MDL are reported from the NWQL as estimated.

Major ions, nutrients, and organic carbon are reported with minimum reporting levels (MRL's), which take into account MDL's and are based on the laboratory's best judgment of the concentration that can be reliably reported using a given analytical method (U.S. Geological Survey, 1999a).

Streamflow measurements in the tributaries were made at the time of sample collection in accordance with standard USGS procedures (Rantz and others, 1982). For the Congaree River at Columbia, streamflow data were obtained from the USGS continuous-measurement gage.

\section{Ecological Characterization}

All ecological samples and data were collected using NAWQA protocols. These protocols specify step-by-step procedures designed to standardize data collected for the NAWQA Program.

\section{Habitat}

Habitat data were collected in accordance with NAWQA protocols (Meador, Hupp, and others, 1993). A section of stream, called a "reach," approximately 150 meters $(\mathrm{m})$ in length was selected for study at each site. Along each reach, six transect sites were constructed at approximately equidistant intervals (about $30 \mathrm{~m}$ ). The following physical attributes were measured at each transect: bankfull width, bank height, water depth, substrate type, embeddedness, and habitat type. The riparian zone was assessed using a pointquarter method. At each transect, a pivot point was chosen at random on each side of the stream up to $3 \mathrm{~m}$ from the bank. From the pivot point, the nearest tree in each quarter (each 90-degree section) was identified. Distance to the pivot point and the diameter of each tree at chest height were measured. Thus, on each side of each transect, four trees were identified and measured. Forty-eight trees were identified at each site.

\section{Aquatic Community}

Algal samples were collected using procedures outlined in Porter and others (1993). For quantitative analysis and taxonomic enumeration, discrete areal samples ranging from 25 to 363 square centimeters $\left(\mathrm{cm}^{2}\right)$ were taken from logs and other woody snags. Discrete areal samples of the bottom material ranging from 98 to $196 \mathrm{~cm}^{2}$ were collected in as many different habitats as were available. For taxonomic evaluation only, qualitative samples of macroalgae and aquatic mosses were collected where these organisms were observed in the streams. At the time of this printing, algal data were not available.

Macroinvertebrates were collected using qualitative and quantitative techniques (Cuffney and others, 1993). The faunistically richest habitat, known as the richest targeted habitat (RTH), in each stream was determined by observation and was sampled by discrete areal collections ranging from 1,155 to $4,745 \mathrm{~cm}^{2}$. The RTH in all streams was judged to be woody snags, or branches and logs, and debris dams. The woody snag habitat is the most prevalent habitat in streams of Congaree Swamp and is relatively stable (compared to easily erodible sandy and muck bottoms). 
Woody snag habitats provide cover for rich, diverse communities of macroinvertebrate fauna.

Macroinvertebrates were collected from branches by picking the branches apart for the organisms of interest. Debris and loose material were processed through a standard brass $425-\mu \mathrm{m}$ sieve. All material, except for the cleaned branches, was preserved in a 10-percent solution of formaldehyde and sent to the NWQL for taxonomic evaluation. Once the combined area was calculated for the branches from which samples were collected, the density of macroinvertebrate fauna was determined. Qualitative samples were collected from logs using forceps and fingers and by searching for individual organisms in leaves and organic detritus. All organisms were sent to the NWQL for taxonomic evaluation.

Fish collections were conducted in accordance with Meador, Cuffney, and Gurtz (1993). A scientific fish-collection permit was obtained from the South Carolina Department of Natural Resources before any collection activities began. Fishes were collected by power-fishing techniques, using a backpack power fisher (Smith-Root, model 12A POW) in all streams. In addition, a non-commercial, boat-mounted, powerfishing apparatus (courtesy of Mr. John Crane, Fisheries Biologist, South Carolina Department of Natural Resources) was used to collect fishes in Cedar Creek near Wise Lake. A commercial boat-mounted power-fishing apparatus (Smith-Root, customized for USGS use) was used to collect fishes in the Congaree River at Columbia.

\section{Tissue}

Tissue samples were collected using NAWQA procedures specified by Crawford and Luoma (1994). The Asiatic clam (Corbicula fluminea) is one of the organisms selected for tissue analysis in the NAWQA Program. The Asiatic clam is widespread in the continental United States and can be used as a common source to standardize information about the bioavailability of trace elements and organic compounds in stream sediments. However, Asiatic clams were not found in Congaree Swamp, so native freshwater clams (Elliptio sp.) were selected for tissue analyses. Because clams are bottom-dwelling filter feeders that only travel short distances, they tend to accumulate trace elements and organic contaminants and can be indicators of water-quality conditions in a discrete area over time (Rodgers and others, 1979; Crawford and Luoma, 1994). Suspected routes of accumulation are ingestion of food particles (algae, bacteria, and organic detritus) from the water column and absorption at the water-gill interface. Analyses for pesticides and trace elements were conducted on the soft tissues of the clams.

The common carp (Cyprinus carpio), also specified in the NAWQA protocols for tissue analyses as a common organism found in most areas of the country, was not present in Congaree Swamp streams. Carp liver tissue was designated for analysis for trace elements because carp are large fish and their livers are easily excised in the field. Analyses for organochlorine pesticides are conducted using the whole fish.

However, for this study, the redbreast sunfish (Lepomis auritus) was selected for tissue analyses because it is one of the most popular game fishes in South Carolina (Barton and O'Brien-White, 1995). Information about this fish's potential as a source of contaminants is relevant and of interest to the fishing public. This fish also represents a higher trophic level (secondary consumer). Typically insectivorous, the redbreast preys on organisms that live in close association with sediments. Trace element analyses of redbreast sunfish liver tissues were not conducted because the fish are relatively small, and liver tissue extraction was not feasible. However, whole-fish analyses of organochlorine pesticides were conducted using redbreast sunfish from Myers Creek, Cedar Creek, and Toms Creek. Cedar Creek near Wise Lake yielded too few redbreast sunfish for analysis.

\section{Bed Sediments}

Bed-sediment samples were collected using procedures specified in the NAWQA Program (Shelton and Capel, 1994). Sediment samples from each of the six sites were collected between 1995 and 1997 from the top few centimeters within depositional zones of streambeds and were wet-sieved to provide a less than $63-\mu \mathrm{m}$ fraction for trace element analysis (Shelton and Capel, 1994). Several sediment subsamples from each site were composited into representative samples and sent to the NWQL for analysis.

\section{RESULTS OF WATER-QUALITY SAMPLING}

Results from the water-quality samples are presented below. Results of the quality-control sample analyses also are presented in the following sections. 


\section{Major lons}

Concentrations of calcium, magnesium, sodium, potassium, sulfate, chloride, and silica were

significantly higher in the Congaree River at Columbia than the four tributary streams (figs. 5, 6; Appendix 1). These ions are naturally occurring, but also are found in surface waters as a result of agricultural runoff or wastewater discharges from industrial and municipal treatment plants (Hem, 1992). A significant inverse correlation of streamflow with sodium and chloride concentrations was detected in the Congaree River at Columbia, possibly an indication of dilution of point sources of these ions. Streamflow was directly correlated with calcium, magnesium, potassium, and sulfate at Cedar Creek near Wise Lake and directly correlated with calcium and sulfate at Cedar Creek. Cedar Creek had significantly lower concentrations of calcium, magnesium, sodium, potassium, and chloride than the other streams (figs. 5, 6) and generally had the least variability in major ion concentrations. Fluoride concentrations in the streams were below or just above the MRL (0.01 milligram per liter [mg/L]). The ranges of major ion concentrations in streams in the study area are presented in table 2. The U.S. Environmental Protection Agency (U.S. EPA) parameter code identifies the specific form of the constituent analyzed and can be used for accurate comparison with other studies of the same constituent.

Concentrations of iron and manganese were significantly lower in the Congaree River at Columbia than in the four tributary streams (fig. 7). Iron and manganese often are present in streams as a result of ground-water discharge to the stream. Microorganisms in subsurface sediments can reduce iron and manganese, making them more soluble in ground water. The higher concentrations of iron and manganese in the four tributary streams than in the Congaree River at Columbia may be because ground water constitutes a more significant portion of the flow in the tributary streams. Secondary drinking-water standards for iron (300 micrograms per liter $[\mu \mathrm{g} / \mathrm{L}]$ ) and manganese $(50 \mu \mathrm{g} / \mathrm{L})$ were exceeded in at least one sample at each site. Secondary drinking-water standards are Federal guidelines regarding taste, odor, color, and other non-aesthetic effects of drinking water (U.S. Environmental Protection Agency, 1996).

The surface-water quality-control data collected for this study indicate that contamination of samples was rare and minimal. Detections of major ions in the blank samples were infrequent and were at or close to the MRL's. The levels detected in the blanks were considered insignificant and do not affect the quality of the data.

Table 2. Ranges in major ion concentrations in streams of Congaree Swamp

[MRL, minimum reporting level; mg/L, milligram per liter; $\mu \mathrm{g} / \mathrm{L}$, microgram per liter]

\begin{tabular}{lccccc}
\hline \multicolumn{1}{c}{ Constituent } & $\begin{array}{c}\text { Parameter } \\
\text { code }\end{array}$ & Minimum & Median & Maximum & MRL \\
\hline Calcium $(\mathrm{mg} / \mathrm{L})$ & 00915 & 0.63 & 1.1 & 4.4 & 0.02 \\
Magnesium $(\mathrm{mg} / \mathrm{L})$ & 00925 & .39 & .78 & 1.8 & .004 \\
Sodium $(\mathrm{mg} / \mathrm{L})$ & 00930 & 1.7 & 3.2 & 11 & .06 \\
Potassium $(\mathrm{mg} / \mathrm{L})$ & 00935 & .4 & 1.0 & 3.3 & .1 \\
Silica $(\mathrm{mg} / \mathrm{L})$ & 00955 & .55 & 7.8 & 14 & .05 \\
Chloride $(\mathrm{mg} / \mathrm{L})$ & 00940 & 2.5 & 4.4 & 8.7 & .1 \\
Fluoride $(\mathrm{mg} / \mathrm{L})$ & 00950 & .1 & .1 & .2 & .1 \\
Sulfate $(\mathrm{mg} / \mathrm{L})$ & 00945 & .43 & 2.2 & 17 & .1 \\
Iron $(\mu \mathrm{g} / \mathrm{L})$ & 01046 & 39 & 305 & 960 & 10 \\
Manganese $(\mu \mathrm{gg} / \mathrm{L})$ & 01056 & 5.0 & 27.5 & 374 & 3.0 \\
\hline
\end{tabular}



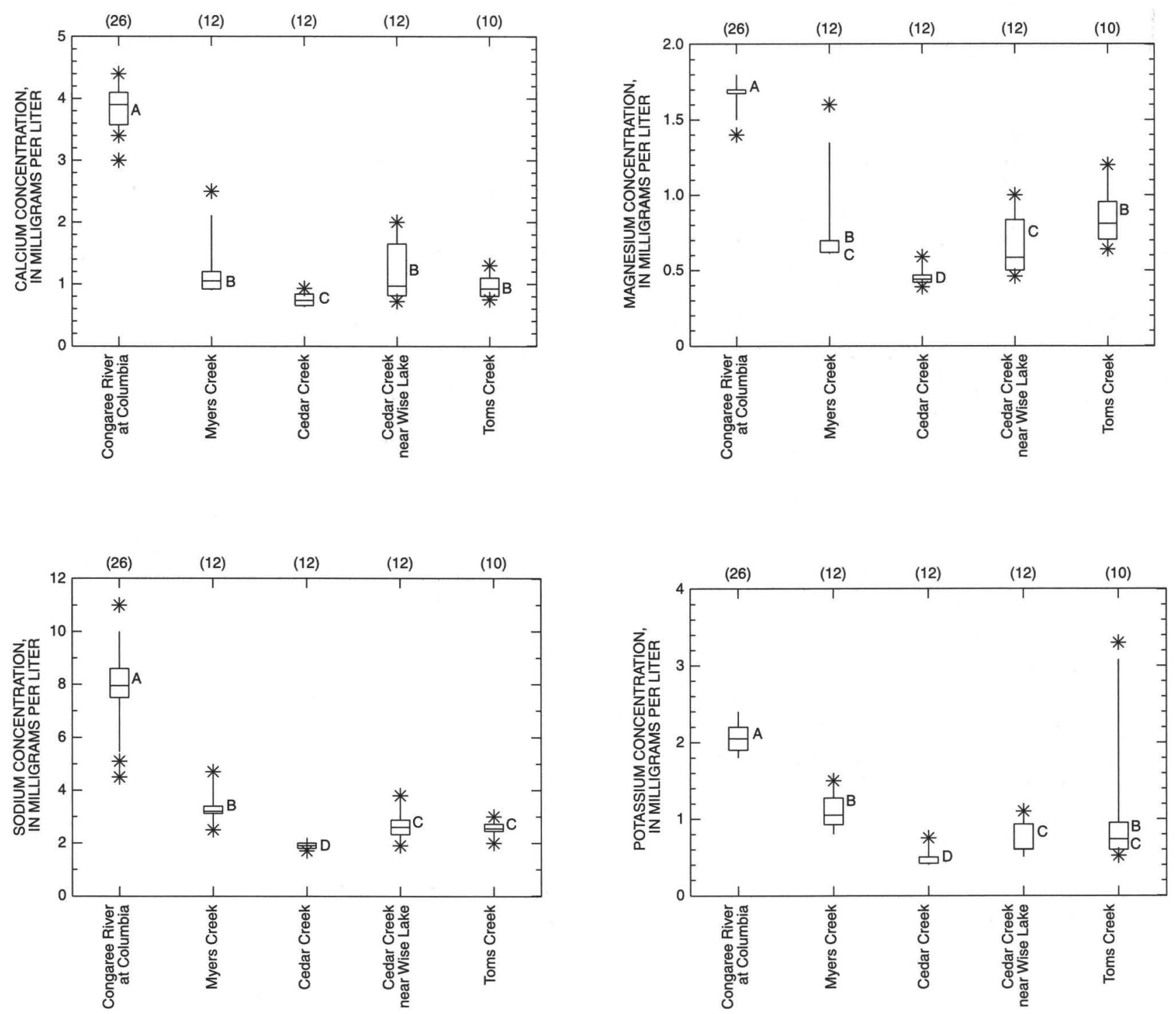

\section{EXPLANATION}

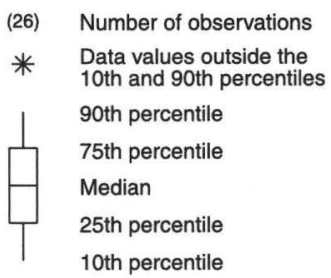

Figure 5. Statistical distribution of calcium, magnesium, sodium, and potassium in streams of Congaree Swamp. (Letters denote significantly different mean concentration ranks, with $A$ being the highest, B being the next lower, and so on. Sites with letters in common are not significantly different from each other.) 

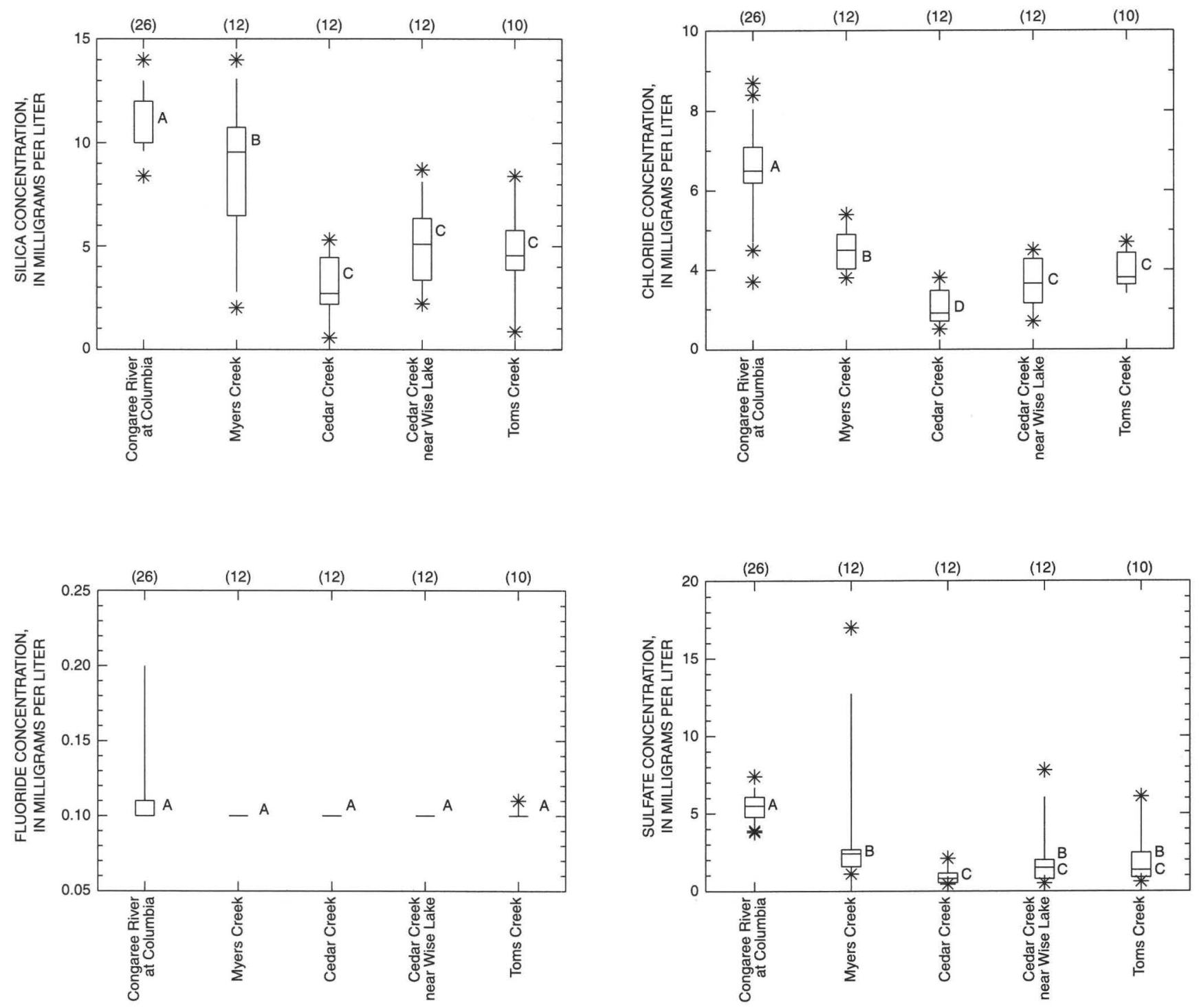

\section{EXPLANATION}

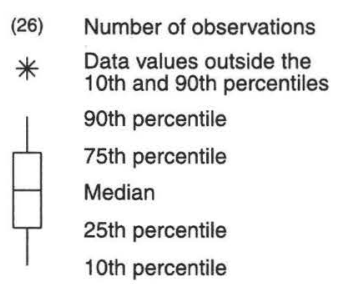

Figure 6. Statistical distribution of silica, chloride, fluoride, and sulfate in streams of Congaree Swamp. (Letters denote significantly different mean concentration ranks, with $\mathrm{A}$ being the highest, $\mathrm{B}$ being the next lower, and so on. Sites with letters in common are not significantly different from each other.) 

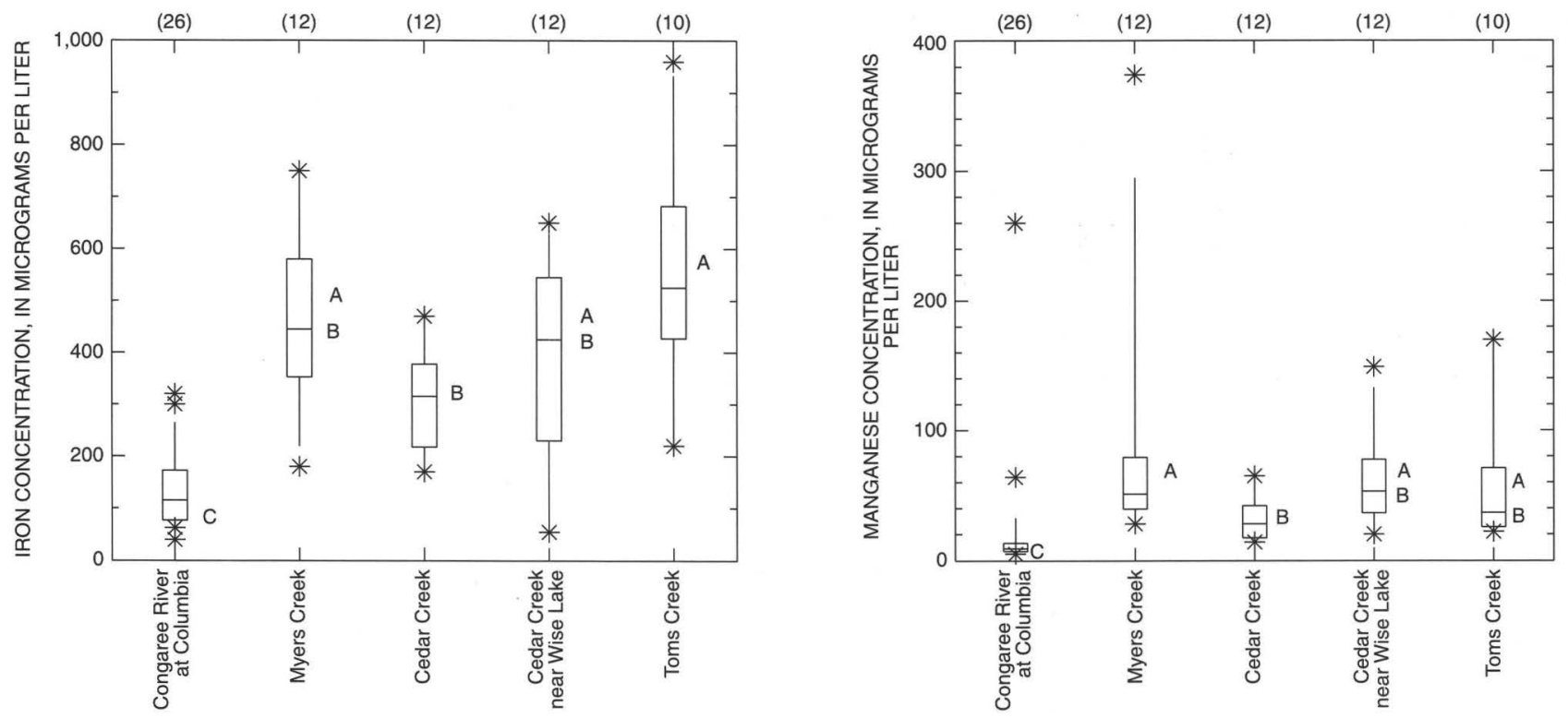

\section{EXPLANATION}

(26) Number of observations

* Data values outside the th and 90th percentiles

90th percentile

75th percentile

Median

25th percentile

10th percentile

Figure 7. Statistical distribution of iron and manganese in streams of Congaree Swamp. (Letters denote significantly different mean concentration ranks, with A being the highest, B being the next lower, and so on. Sites with letters in common are not significantly different from each other.) 


\section{Nutrients}

Nutrient concentrations in streams in the study area generally were low (table 3; Appendix 2). All ammonia nitrogen concentrations were below $0.15 \mathrm{mg} / \mathrm{L}$, with no significant differences among sites (fig. 8). Myers and Toms Creeks had the highest median ammonia-plus-organic nitrogen concentrations, but variability in concentrations was low. Much of the ammonia-plus-organic nitrogen was in the dissolved phase in the four tributary streams, and in the particulate phase in the Congaree River at Columbia. Nitrite nitrogen concentrations were low with little variability. Nitrite-plus-nitrate nitrogen concentrations were significantly higher in the Congaree River at Columbia than in the four tributary streams, but no sample exceeded 0.5 mg/L. Detections of low-level nutrients in the quality-control samples were infrequent. Elevated concentrations of nitrite-plus-nitrate nitrogen and ammonia nitrogen were detected in one field-blank sample from the Congaree River at Columbia. The level detected was approximately twice the MRL. Because it was a single occurrence, sample data integrity was not affected.

Phosphorus concentrations varied little among sites (fig. 9). Dissolved phosphorus concentrations were highest in the Congaree River at Columbia, and total phosphorus concentrations in the Congaree River at Columbia were significantly greater than in Cedar and Toms Creeks. The U.S. EPA (1986) recommends that instream concentrations of total phosphorus not exceed $0.10 \mathrm{mg} / \mathrm{L}$ in flowing waters not entering lakes or impoundments, $0.05 \mathrm{mg} / \mathrm{L}$ in flowing waters at the point of entry to a lake or impoundment, and $0.025 \mathrm{mg} / \mathrm{L}$ within lakes or impoundments. All phosphorus concentrations in Myers Creek, Cedar Creek, Cedar Creek near Wise Lake, and Toms Creek were below $0.10 \mathrm{mg} / \mathrm{L}$. Total phosphorus concentrations in the Congaree River at Columbia exceeded $0.10 \mathrm{mg} / \mathrm{L}$ in 5 of 26 samples.

Table 3. Ranges in nutrient concentrations in streams of Congaree Swamp

[Units in milligrams per liter; MRL, minimum reporting level]

\begin{tabular}{|c|c|c|c|c|c|}
\hline Constituent & $\begin{array}{c}\text { Parameter } \\
\text { code }\end{array}$ & Minimum & Median & Maximum & MRL \\
\hline Ammonia nitrogen & 00608 & 0.015 & 0.020 & 0.120 & 0.015 \\
\hline Dissolved ammonia-plus-organic nitrogen & 00623 & .10 & .20 & .51 & .10 \\
\hline Total ammonia-plus-organic nitrogen & 00625 & .10 & .30 & 1.0 & .10 \\
\hline Nitrite nitrogen & 00613 & .01 & .01 & .02 & .01 \\
\hline Nitrite-plus-nitrate nitrogen & 00631 & .05 & .20 & .42 & .05 \\
\hline Orthophosphorus & 00671 & .01 & .01 & .03 & .01 \\
\hline Dissolved phosphorus & 00666 & .01 & .01 & .04 & .01 \\
\hline Total phosphorus & 00665 & .01 & .02 & .35 & .01 \\
\hline Dissolved organic carbon & 00681 & 1.4 & 3.6 & 16 & .1 \\
\hline Suspended organic carbon & 00689 & .1 & .8 & 4.8 & $.2^{\mathrm{a}}$ \\
\hline
\end{tabular}

${ }^{a}$ MRL increased from 0.1 to 0.2 during the study. 

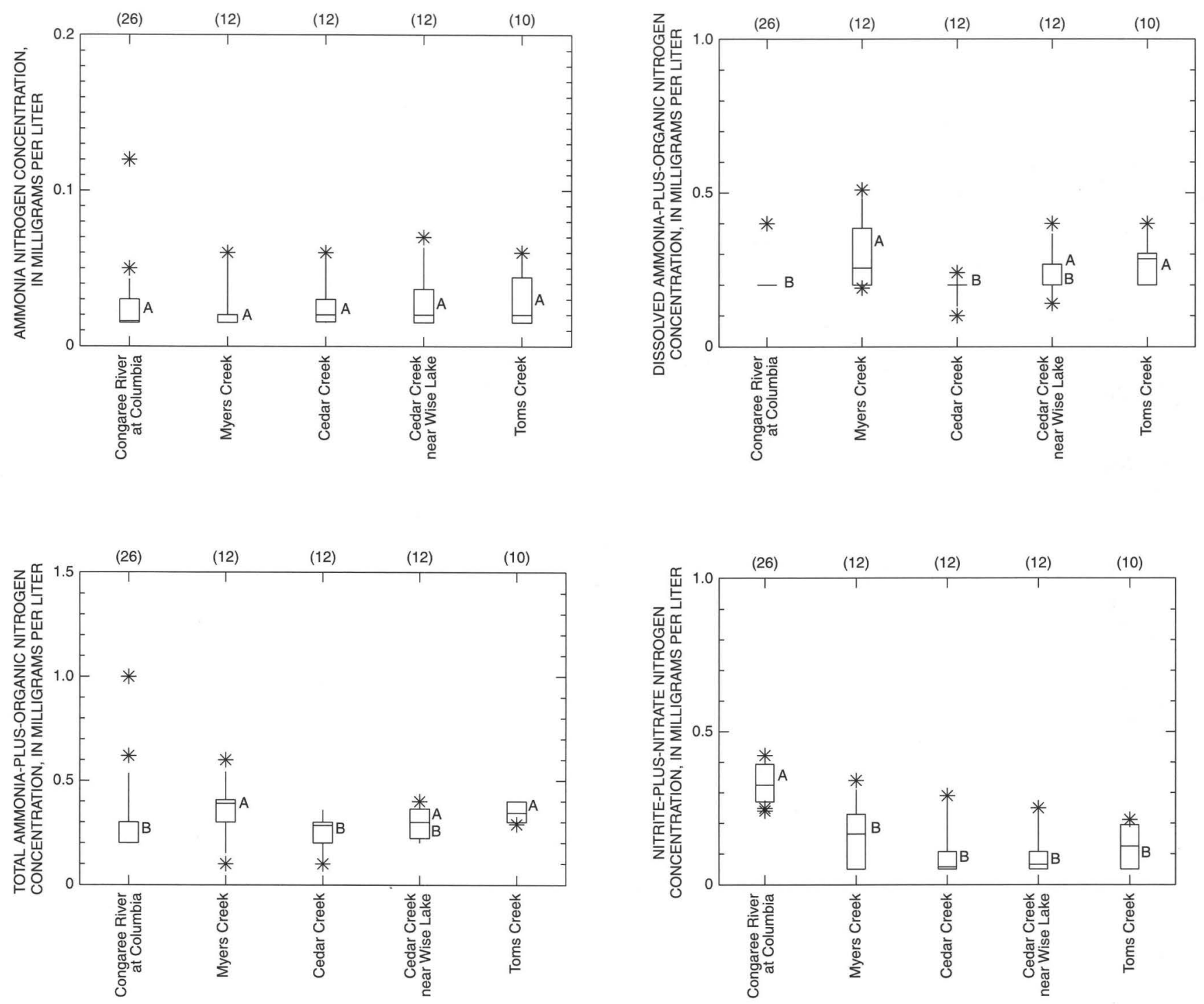

\section{EXPLANATION}

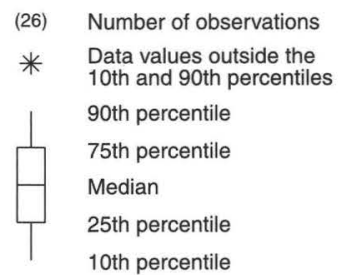

Figure 8. Statistical distribution of nitrogen species in streams of Congaree Swamp. (Letters denote significantly different mean concentration ranks, with A being the highest, B being the next lower, and so on. Sites with letters in common are not significantly different from each other.) 

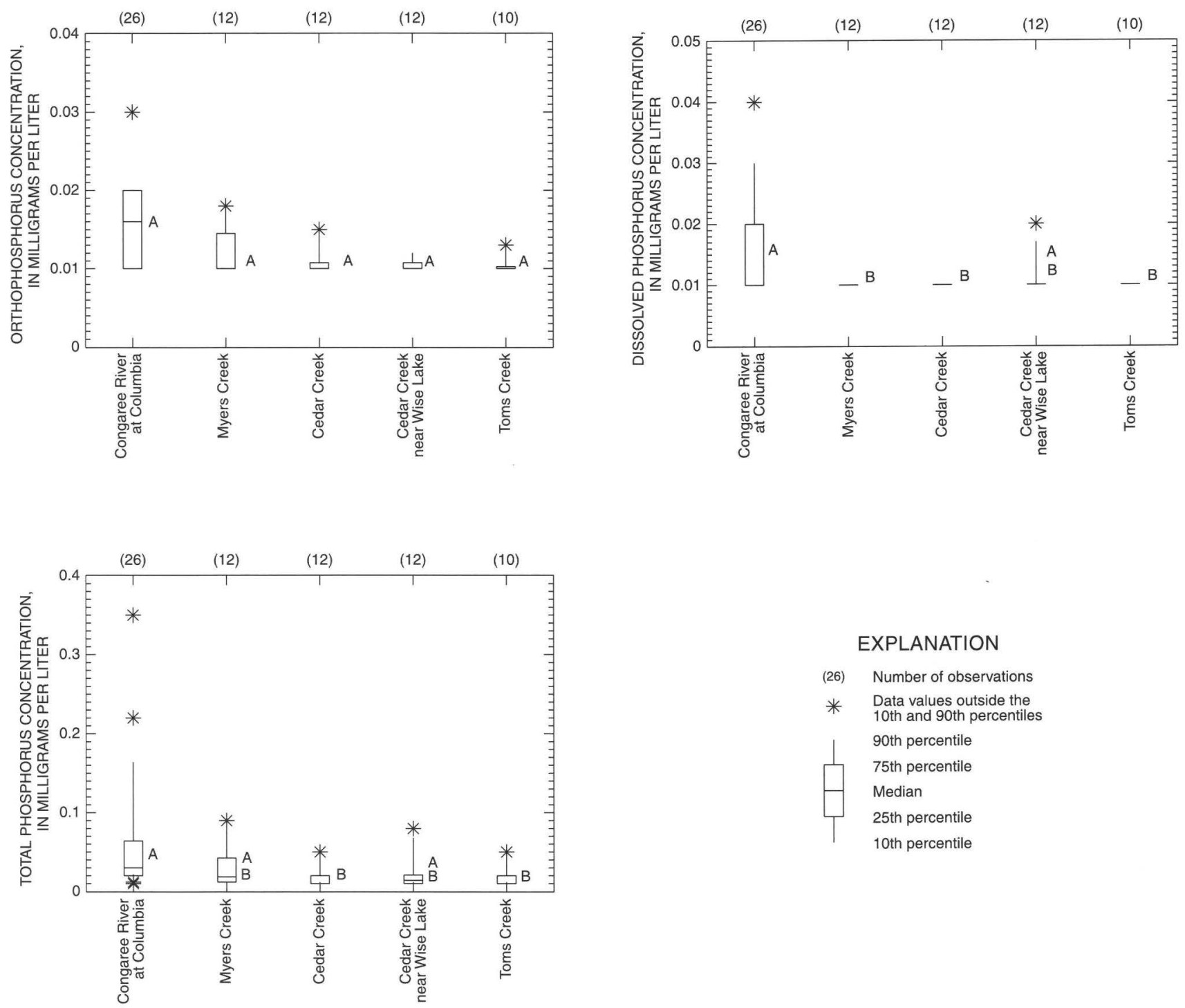

EXPLANATION

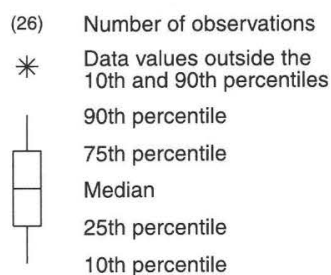

Figure 9. Statistical distribution of phosphorus species in streams of Congaree Swamp. (Letters denote significantly different mean concentration ranks with A being the highest, B being the next lower, and so on. Sites with letters in common are not significantly different from each other.) 
Dissolved organic carbon concentrations were highest in Myers Creek (fig. 10). Suspended organic carbon concentrations were significantly lower in the Congaree River at Columbia than in the four tributary streams. Detections of organic carbon in the qualitycontrol samples were close to the MRL.

\section{Pesticides}

Forty-two water samples were collected from the streams of Congaree Swamp and analyzed for 47 pesticides-3 samples from the Congaree River at Columbia, 10 each from Myers Creek, Cedar Creek, and Cedar Creek near Wise Lake, and 9 from Toms Creek (Appendixes 3, 4). The number of samples differs because of different sampling regimes among the sites. Quarterly pesticide sampling was conducted at the Congaree River at Columbia from February to October 1996; quarterly sampling at the other four sites was conducted approximately from January 1996 through September 1998. Twelve different pesticides were detected. Tebuthiuron, atrazine, metolachlor, and deethylatrazine were the most frequently detected pesticides (table 4; Appendix 4). The number of detections varied with each pesticide and ranged from 2 to 90 percent of the samples collected at all of the streams.

Pesticide concentrations ranged from below the MDL's to a high of $0.084 \mu \mathrm{g} / \mathrm{L}$ for tebuthiuron at Toms Creek. None of the pesticide concentrations exceeded criteria for the protection of human health or aquatic life (table 4). Significantly higher concentrations of atrazine and metolachlor were detected in the spring than in the fall or winter. These herbicides are typically
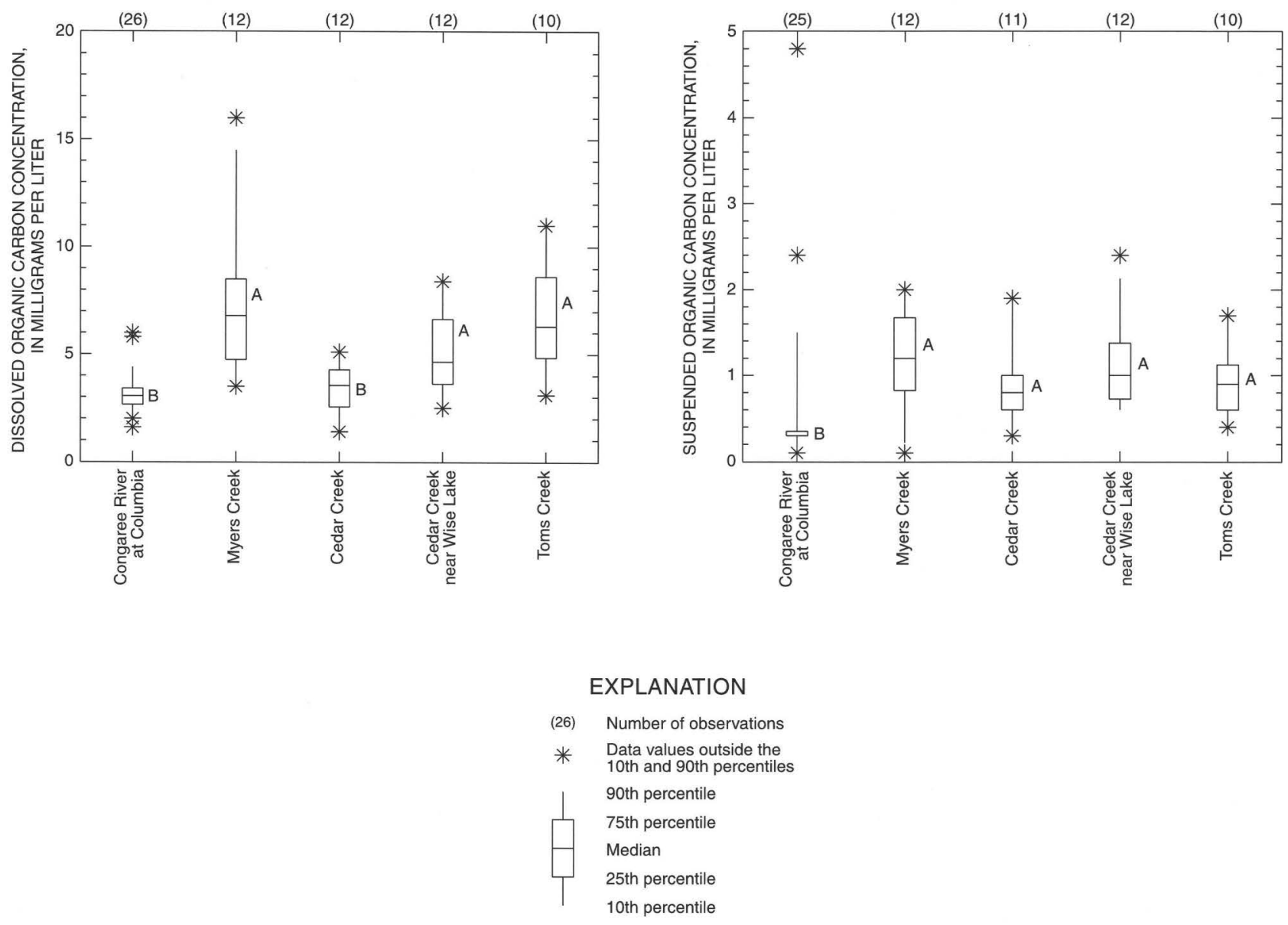

Figure 10. Statistical distribution of organic carbon in streams of Congaree Swamp. (Letters denote significantly different mean concentration ranks, with A being the highest, B being the next lower, and so on. Sites with letters in common are not significantly different from each other.) 
Table 4. Summary of pesticides detected in streams of Congaree Swamp

[Units in micrograms per liter; HAL, health advisory level; MCL, maximum contaminant level; —, not established]

\begin{tabular}{|c|c|c|c|c|c|c|}
\hline Pesticide & $\begin{array}{c}\text { Number } \\
\text { of } \\
\text { detections }\end{array}$ & $\begin{array}{c}\text { Percentage } \\
\text { of } \\
\text { detections }\end{array}$ & $\begin{array}{c}\text { Maximum } \\
\text { concentration }\end{array}$ & $\begin{array}{l}\text { Aquatic } \\
\text { criteria }\end{array}$ & $\begin{array}{c}\text { Lifetime } \\
\text { HAL }\end{array}$ & MCL \\
\hline \multicolumn{7}{|c|}{$\begin{array}{r}\text { Herbicides } \\
\end{array}$} \\
\hline Tebuthiuron & 38 & 90 & 0.084 & - & 500 & - \\
\hline Atrazine & 25 & 60 & .058 & - & $3^{\mathrm{a}}$ & 3 \\
\hline Metolachlor & 23 & 55 & .038 & - & 70 & - \\
\hline Deethylatrazine $^{b}$ & 16 & 38 & .004 & - & - & - \\
\hline Prometon $^{\mathrm{b}}$ & 5 & 12 & .009 & - & $100^{\mathrm{a}}$ & - \\
\hline Simazine & 5 & 12 & .053 & $10^{\mathrm{c}}$ & 4 & 4 \\
\hline DCPA & 2 & 5 & .001 & - & - & - \\
\hline Alachlor $^{b}$ & 1 & 2 & .002 & - & - & 2 \\
\hline Pronamide & 1 & 2 & .006 & 一 & 50 & - \\
\hline \multicolumn{7}{|c|}{ Insecticides } \\
\hline Carbaryl $^{b}$ & 1 & 2 & 0.006 & $0.02^{\mathrm{c}}$ & 700 & - \\
\hline Chlorpyrifos $^{b}$ & 1 & 2 & .004 & $.041^{\mathrm{d}}$ & 20 & - \\
\hline Diazinon & 1 & 2 & .003 & $.009^{c}$ & .6 & - \\
\hline
\end{tabular}

${ }^{\mathrm{a} U n d e r ~ r e v i e w ~(U . S . ~ E n v i r o n m e n t a l ~ P r o t e c t i o n ~ A g e n c y, ~ 1996) . ~}$

${ }^{\mathrm{b}}$ Concentrations for these pesticides are qualitatively identified with an E code (estimated; Zaugg and others, 1995).

${ }^{c}$ Freshwater chronic water-quality criteria recommendations are from National Academy of Sciences and National Academy of Engineering (1973), modified from Nowell and Resek (1994).

${ }^{d}$ Freshwater chronic water-quality criteria (U.S. Environmental Protection Agency, 1997).

detected in higher concentrations during spring application and runoff periods.

Although the Congaree River at Columbia had the fewest number of pesticide samples (3), it had the highest number of different pesticides detected (9). Cedar Creek and Toms Creek (10 and 9 samples, respectively) had the lowest number of different pesticides detected (5). Myers Creek had the highest number of pesticide detections (28), and Cedar Creek had the lowest number (19; table 5). No pesticides were detected in the quality-control samples.

Tebuthiuron and prometon are herbicides used for broadleaf and grassy weed control in non-cropland areas, highway right-of-ways, and industrial sites. Atrazine and simazine are widely used triazine herbicides for control of broadleaf and grassy weeds on croplands and as non-selective herbicides on industrial and fallow lands. Deethylatrazine is a breakdown product of atrazine. Metolachlor is used as a preemergent herbicide for broadleaf and grassy weed control on croplands and highway right-of-ways.
Chlorthal, also called DCPA, is a pre-emergent herbicide used on croplands and on home lawns and gardens. Alachlor is a selective herbicide used to control broadleaf weeds and grasses in field corn, soybeans, and peanuts. Pronamide, also known as propyzamide, is a herbicide used for both pre- and postemergent weed control on lettuce, alfalfa, blueberries, ornamental plants, fruit trees, and fallow lands.

Carbaryl is used as a wide-spectrum carbamate insecticide for citrus and other fruit trees, cotton, forests, lawns, and other croplands, as well as on poultry, livestock, and pets. Chlorpyrifos is an organophosphate insecticide used on grain, cotton, fields, fruit and nut trees, vegetable crops, lawns, and ornamental plants. It also is used on sheep and turkeys, and to treat homes and farm buildings, dog kennels, and commercial buildings. Diazinon is an organophosphate insecticide used for residential control of roaches, silverfish, ants, and fleas. It also is used on home gardens and farms to control a wide variety of insects. 
Table 5. Numbers of pesticide detections in streams of Congaree Swamp

\begin{tabular}{lccccc}
\hline \multicolumn{1}{c}{ Pesticide } & $\begin{array}{c}\text { Congaree River } \\
\text { at Columbia } \\
\text { (3 samples) }\end{array}$ & $\begin{array}{c}\text { Myers } \\
\text { Creek } \\
\text { (10 samples) }\end{array}$ & $\begin{array}{c}\text { Cedar } \\
\text { Creek } \\
\text { (10 samples) }\end{array}$ & $\begin{array}{c}\text { Cedar Creek } \\
\text { near Wise Lake } \\
\text { (10 samples) }\end{array}$ & $\begin{array}{c}\text { Toms } \\
\text { Creek } \\
\text { (9 samples) }\end{array}$ \\
\hline Alachlor & 0 & 0 & 1 & 0 & 0 \\
Atrazine & 3 & 6 & 5 & 6 & 5 \\
Carbaryl & 0 & 0 & 0 & 0 & 1 \\
Chlorpyrifos & 0 & 1 & 0 & 0 & 0 \\
DCPA & 2 & 0 & 0 & 0 & 0 \\
Deethylatrazine & 3 & 3 & 1 & 3 & 6 \\
Diazinon & 1 & 0 & 0 & 0 & 0 \\
Metolachlor & 3 & 7 & 3 & 1 & 5 \\
Prometon & 3 & 1 & 0 & 0 & 0 \\
Pronamide & 1 & 0 & 0 & 1 & 0 \\
Simazine & 3 & 1 & 0 & 9 & 0 \\
Tebuthiuron & 3 & 9 & 9 & 24 & 9 \\
\hline Total number of detections & 22 & 28 & 19 & & 0 \\
\hline
\end{tabular}

\section{Suspended Sediment}

The Congaree River at Columbia had significantly higher concentrations of suspended sediment than Cedar and Toms Creeks (fig. 11; Appendix 5). Suspended-sediment concentrations ranged from 1 to $248 \mathrm{mg} / \mathrm{L}$. The percentage of suspended sediment finer than 0.062 millimeters $(\mathrm{mm})$ ranged from 14 to 96 percent. No significant differences were detected among study sites in the percentage of the suspended sediment finer than $0.062 \mathrm{~mm}$.

\section{Field Measurements}

Measurements of streamflow, specific conductance, stream temperature, $\mathrm{pH}$, dissolved oxygen concentration and percent saturation, and alkalinity were made at the study sites each time a water-quality sample was collected (Appendix 6). Streamflow ranged from 1 cubic foot per second $\left(\mathrm{ft}^{3} / \mathrm{s}\right)$ to $160 \mathrm{ft}^{3} / \mathrm{s}$ on sampling dates in the four tributary streams, and from $2,400 \mathrm{ft}^{3} / \mathrm{s}$ to more than $53,000 \mathrm{ft}^{3} / \mathrm{s}$ during sampling on the Congaree River at Columbia. Specific conductance, alkalinity, and $\mathrm{pH}$ were significantly higher in the Congaree River at Columbia than in the four tributary streams. Specific conductance ranged from 11 microsiemens per centimeter at $25^{\circ} \mathrm{C}(\mu \mathrm{S} / \mathrm{cm})$ to more than $100 \mu \mathrm{S} / \mathrm{cm}$. Alkalinity was generally below $10 \mathrm{mg} / \mathrm{L}$ in the four tributary streams and ranged from $12 \mathrm{mg} / \mathrm{L}$ to $36 \mathrm{mg} / \mathrm{L}$ in the Congaree River at Columbia. Low alkalinity, or buffering capacity, resulted in lower $\mathrm{pH}$ in the four tributary streams. The median $\mathrm{pH}$ in the tributaries was below 6.0 standard units (su), and was over $7.0 \mathrm{su}$ in the Congaree. No significant differences were detected in stream temperatures. Stream temperatures ranged from $6{ }^{\circ} \mathrm{C}$ to $29^{\circ} \mathrm{C}$, and median stream temperatures ranged from $16^{\circ} \mathrm{C}$ to $20^{\circ} \mathrm{C}$. No significant differences were detected in dissolved oxygen concentrations in the streams, but Cedar Creek had a significantly higher percentage of saturation of dissolved oxygen than the other three tributary streams, possibly due to less organic detritus in Cedar Creek. Median percentages of dissolved oxygen saturation ranged from more than 75 percent to about 99 percent.

\section{RESULTS OF ECOLOGICAL CHARACTERIZATION}

The characteristics of the tributary stream reaches were determined by onsite investigations. Measurements of physical, chemical, biotic, and geologic components were performed in accordance with NAWQA protocols. 

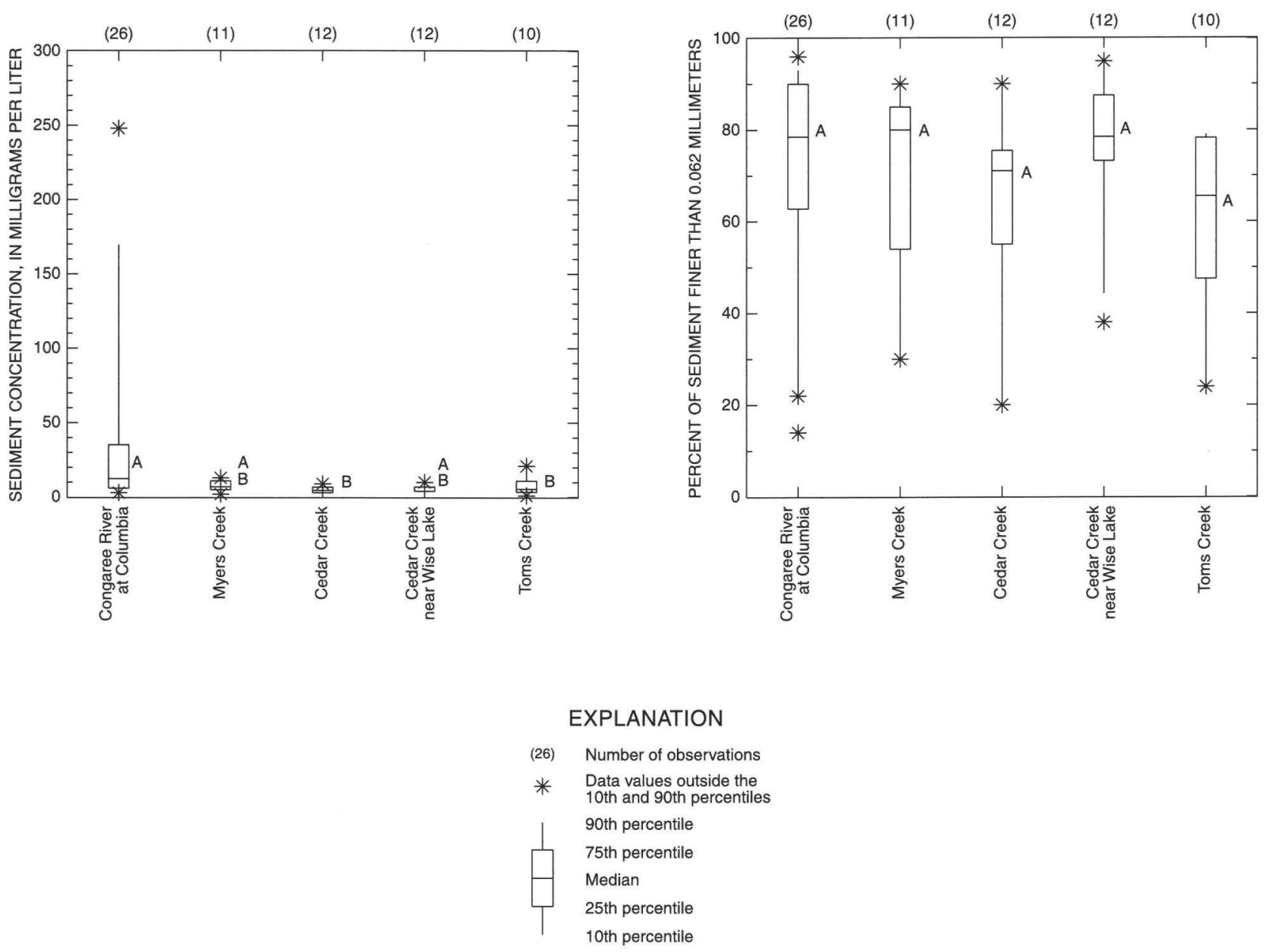

Figure 11. Statistical distribution of suspended sediment in streams of Congaree Swamp. (Letters denote significantly different mean concentration ranks, with A being the highest, B being the next lower, and so on. Sites with letters in common are not significantly different from each other.)

\section{Habitat}

Habitat and stream characteristics are important influences on aquatic fauna distribution. An inventory of habitat characteristics was conducted in each stream (table 6; Appendix 7). Cedar and Toms Creeks have clean sandy bottoms interspersed with patches of woody snags, defined as "trees, branches, or other woody debris of terrestrial origin that extend into the water column" (Meador, Hupp, and others, 1993) that cause debris dams to build up. Cedar Creek is relatively straight and shallow, but has one deep pool at the single bend in the reach. The reach in Cedar Creek is downstream from Duffies Pond. The reach at Toms Creek has a deep pool at the outside edge of each of two meanders.
Myers Creek and Cedar Creek near Wise Lake have different characteristics than the other streams. Bed sediments in Myers Creek and Cedar Creek near Wise Lake are characterized by a deep layer $(0.25$ to $1.0 \mathrm{~m}$ ) of organic detritus (plant debris), fine particulate organic matter (muck), and silt along nearly the entire length of each reach. However, the reach in Myers Creek has dual characteristics. Transect T-1 has a sandy substrate at point 1 , and the entire width of transect T-6 has a sandy substrate dominated by aquatic macrophytes. The reach at Myers Creek has a few deep pools but no meanders. The reach at Cedar Creek near Wise Lake is deeper (1.64-m average depth) than the other three streams (table 6; Appendix 7).

All four streams have extensive bank undercutting supported by thick masses of riparian tree 
Table 6. Habitat characteristics of streams in Congaree Swamp

[m, meter; nm, not measured; SA, sand; OD, organic debris; SI, silt; MU, muck (fine particulate organic material); NO, none; <, less than; $\mathrm{ft}^{3} / \mathrm{s}$, cubic foot per second]

\begin{tabular}{|c|c|c|c|c|c|}
\hline Characteristic & $\begin{array}{c}\text { Congaree } \\
\text { River at } \\
\text { Columbia }\end{array}$ & Myers Creek & Cedar Creek & $\begin{array}{c}\text { Cedar Creek } \\
\text { near Wise Lake }\end{array}$ & Toms Creek \\
\hline Reach length (m) & 2,896 & 159 & 168 & 271 & 155 \\
\hline Mean width (m) & $130-190$ & 9.3 & 7.1 & 38 & 6.7 \\
\hline Mean depth (m) at thalweg ${ }^{\mathrm{a}}$ & $\mathrm{nm}$ & .92 & 1.46 & 1.64 & .78 \\
\hline Dominant substrate & SA & OD & SA & OD & SA \\
\hline Subordinate substrate & SI & MU & NO & MU & NO \\
\hline Embeddedness $^{\mathrm{b}}$ & 2 & 0 & 0 & 0 & 0 \\
\hline Canopy angle $^{\mathrm{c}}$ (degrees) & 180 & 0 & 10 & 28 & 8 \\
\hline Percent woody snags & $<1$ & 21 & 27 & 22 & 30 \\
\hline Mean bank height ${ }^{\mathrm{d}}(\mathrm{m})$ & $\mathrm{nm}$ & .97 & 1.55 & 2.39 & 1.07 \\
\hline Bank vegetation stability ${ }^{\mathrm{e}}$ & $\mathrm{nm}$ & 2 & 4 & 3 & 4 \\
\hline Mean discharge $\left(\mathrm{ft}^{3} / \mathrm{s}\right)$ & 6,120 & 14.35 & 37.5 & 52 & 23 \\
\hline
\end{tabular}

${ }^{\mathrm{a}}$ The thalweg is the deepest part of the channel.

${ }^{b}$ Embeddedness is a numerical rating that describes the extent to which coarse material, such as boulders, cobbles, and bedrock, is covered by fine material (sand, silt, muck). An embeddedness rating of zero (0) indicates that no coarse material is visible; 1 indicates that more than 75 percent of the surface area of gravel, cobble, and boulder particles are covered by fine sediment; 2 indicates that $51-75$ percent of the surface area of gravel, cobble, and boulder particles are covered by fine sediment.

${ }^{c}$ The canopy angle is a measure of the openness of the vegetation overhanging the stream. The lower the canopy angle, the more vegetative shading over the stream at that point.

${ }^{d}$ Bank height is the vertical distance between the thalweg and the level of the bankfull discharge point at the transect being measured.

${ }^{\mathrm{e}} \mathrm{Bank}$ vegetation stability is an assessment of the ability of bank vegetation to resist erosion. It is evaluated using a rating based on four classes that represent percent coverage of the bank surface. The rating includes only that part of the bank that is within $2 \mathrm{~m}$ of either side of the transect, to the top of the bank. A rating of 4 indicates that more than 80 percent of the bank surface is covered by vigorous vegetation. A rating of 3 indicates that 50-79 percent of the bank surface is covered, and a rating of 2 indicates $25-49$ percent coverage (Meador, Hupp, and others, 1993).

roots. Some of the undercuts extend more than $2 \mathrm{~m}$ into the streambank and provide sheltered habitat for fishes and other organisms.

The ecological site reach in the Congaree River at Columbia is representative of a large river reach. It is influenced by the combined flows of two rivers that have been impounded. Periodic and frequent flushing of the reach occurs as water is released from the impoundments causing scouring of habitat. Scouring occurs when sediments are forced against habitat structures by the water current in a process similar to sand blasting. The sandy substrate is unstable, and periods of low flow between flushing result in deposition of sediments carried by the streams.

The immediate banks (riparian zone) of streams in the study area can be characterized by the types of vegetation growing in these areas. Trees are the dominant vegetation along the riparian zones of the streams of Congaree Swamp. The red maple (Acer rubrum) is the dominant tree at Cedar, Toms, and Myers Creeks (table 7). At Cedar Creek near Wise Lake, the dominant tree is the tupelo (Nyssa aquatica), which represents 71 percent of the trees along the reach. Other trees present in large percentages in the study reaches include laurel oak (Quercus laurifolia), sweetgum (Liquidambar styraciflua), and American holly (Ilex opaca). Quarterpoint tree determinations were not required for the large rivers of the NAWQA study. Congaree River bank and island trees are predominantly willows (Salix sp.).

\section{Aquatic Community}

The aquatic community was assessed by studying the results of macroinvertebrate and fish collection. Standard NAWQA protocols were employed in all collections. 
Table 7. Riparian zone dominant tree species and population percentages

[ - not a dominant tree, determined as presence greater than or equal to 15 percent of trees censused]

\begin{tabular}{llcccc}
\hline \multicolumn{1}{c}{ Scientific name } & Common name & $\begin{array}{c}\text { Myers } \\
\text { Creek }\end{array}$ & $\begin{array}{c}\text { Cedar } \\
\text { Creek }\end{array}$ & $\begin{array}{c}\text { Cedar Creek } \\
\text { near Wise } \\
\text { Lake }\end{array}$ & $\begin{array}{c}\text { Toms } \\
\text { Creek }\end{array}$ \\
\hline Acer rubrum & Red maple & 35 & 27 & - & 35 \\
Ilex opaca & American holly & - & 23 & - & - \\
Liquidambar styraciflua & Sweetgum & 33 & 21 & - & 21 \\
Nyssa aquatica & Tupelo & - & - & 17 & - \\
Quercus laurifolia & Laurel oak & - & - & 27 \\
\hline
\end{tabular}

\section{Macroinvertebrates}

The diversity (number of taxa) of the macroinvertebrate community is similar among all four sites (fig. 12, Appendix 8). However, the density of organisms (numbers per unit area) reflects the different habitats available (fig. 13). The similarities of Myers Creek and Cedar Creek near Wise Lake are reflected by the very similar taxa numbers and densities of macroinvertebrates. Likewise, the habitat similarities of Cedar Creek and Toms Creek are reflected by their similar macroinvertebrate densities.
Several measurements (metrics) of stream health or water quality, based on macroinvertebrate community statistics, are available. The metrics and their applications must be adjusted for each type of stream and usually are reported with reference to the geographical location of the stream. For the streams in Congaree Swamp, best professional judgment was used to determine which metrics were applicable. The metrics chosen are a subset of the rapid bioassessment protocols developed by the U.S. EPA (Plafkin and others, 1989). Use of the metrics requires comparison of the macroinvertebrate data with data collected from

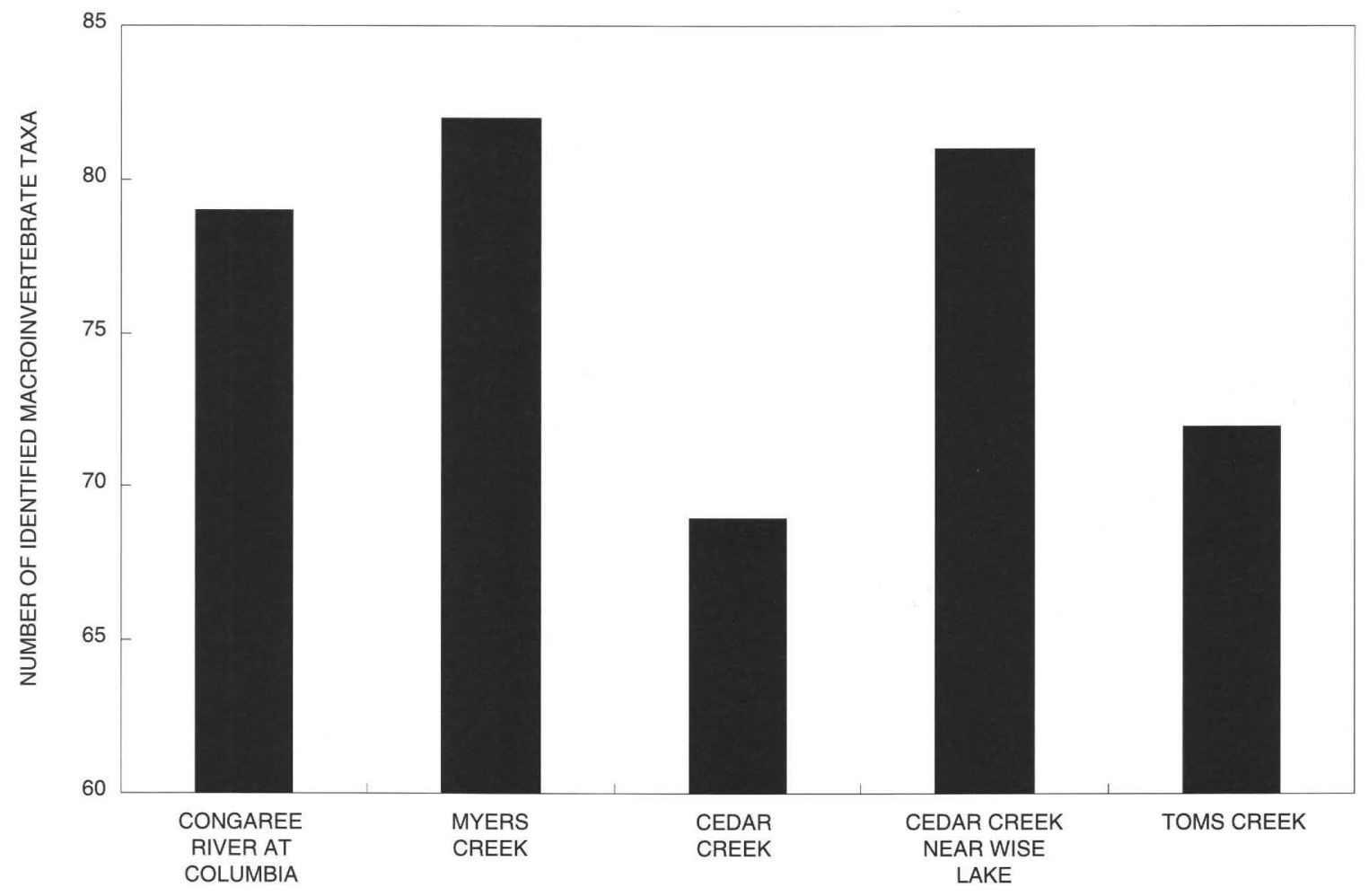

Figure 12. Number of distinct macroinvertebrate taxa identified in streams of Congaree Swamp. 


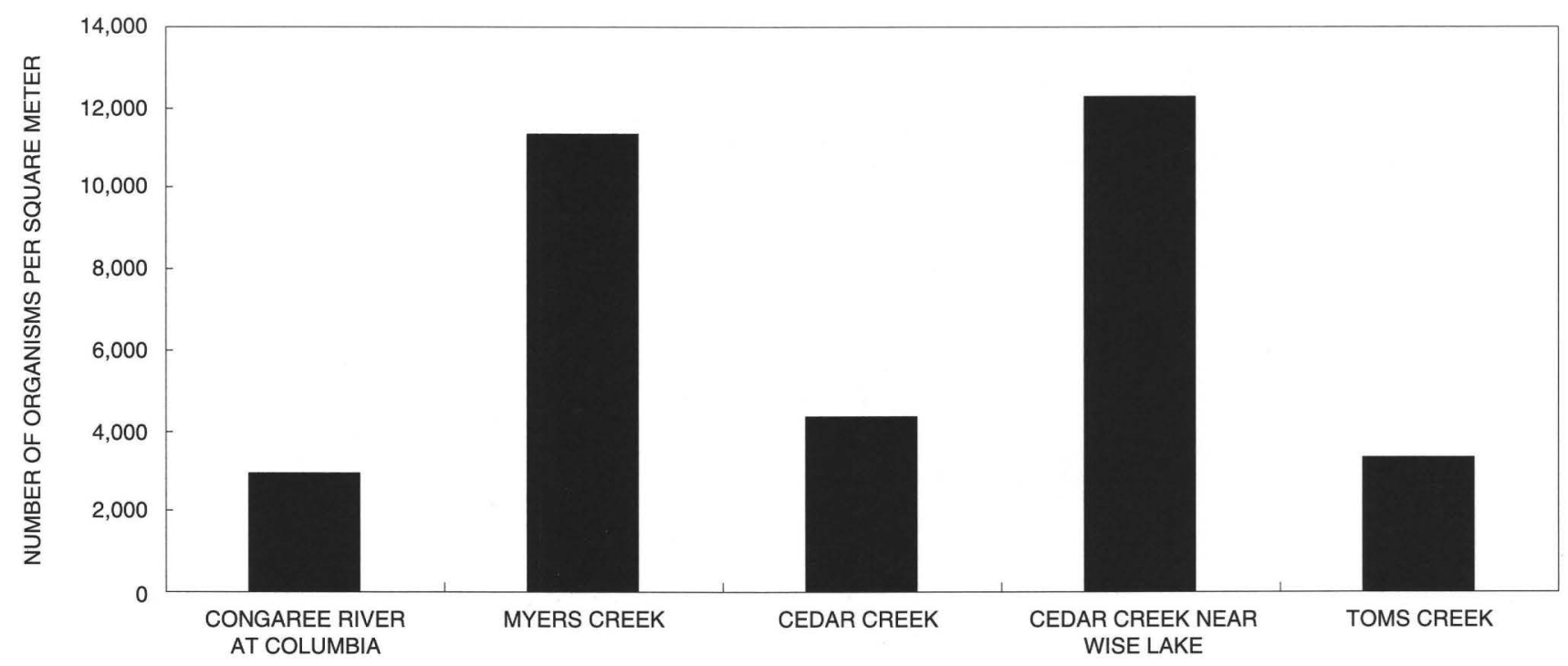

Figure 13. Macroinvertebrate density in streams of Congaree Swamp.

a reference stream. For purposes of this comparison, the Coosawhatchie River, also a blackwater system, was selected as the reference stream because of its similarity to the blackwater streams in Congaree Swamp.

The Coosawhatchie River is a fourth order, highly anastomosing stream in the Lower Coastal Plain of South Carolina. It is an unregulated stream with a drainage basin of $1,036 \mathrm{~km}^{2}$. The study site on the Coosawhatchie River is approximately $122 \mathrm{~km}$ south of Congaree Swamp. Land cover in the Coosawhatchie River Basin is approximately 42 percent agricultural, 30 percent forested, and 24 percent wetlands.

For comparison with a reference stream, the macroinvertebrate data for each metric are assigned a biotic condition score (table 8). Scoring criteria are based on percent comparability to the reference stream, and the scores fall into four broad categories: nonimpaired, slightly impaired, moderately impaired, and severely impaired. Results indicate the relative health of the macroinvertebrate community of each stream compared to the reference stream.

Species richness reflects the health of the community based on the total number of species or genera. Species richness generally increases with increasing water quality, habitat suitability, and habitat diversity.

The percentage contribution of the numerically dominant taxon indicates the community balance. The
EPT (Ephemeroptera, Plecoptera, Trichoptera) index is the total number of distinct taxa within these three orders of insects. Insects of these orders generally are sensitive to pollution, and the index increases with increasing water quality.

The fourth metric, EPT/Chironomid abundance ratio, uses relative abundance of four indicator groups-Ephemeroptera (mayflies), Plecoptera (stoneflies), Trichoptera (caddisflies), and Chironomids (midges). Fairly even distribution among the four groups, with substantial representation of the three most sensitive groups (mayflies, stoneflies, and caddisflies), is indicative of good biotic conditions. Chironomids tend to become increasingly dominant with increasing enrichment and(or) heavy metals concentrations (Ferrington, 1987).

The biotic condition scores indicate that the water quality of Cedar Creek near Wise Lake is impaired in comparison with the Coosawhatchie River. The biotic condition score is emphasized by the contribution of the numerically dominant taxon. In Cedar Creek near Wise Lake, the numerically dominant taxon is the family Chironomidae, which consists of 64 percent of the macroinvertebrate fauna (numerically), but only 25 percent of the total species. Communities in which the fauna are dominated by relatively few taxa are indicative of some type of environmental stress (Plafkin and others, 1989). 
Table 8. Macroinvertebrate biotic condition score computation

[na, not applicable]

\begin{tabular}{|c|c|c|c|c|c|c|}
\hline Metrics & $\begin{array}{l}\text { Congaree } \\
\text { River at } \\
\text { Columbia }\end{array}$ & $\begin{array}{l}\text { Myers } \\
\text { Creek }\end{array}$ & $\begin{array}{l}\text { Cedar } \\
\text { Creek }\end{array}$ & $\begin{array}{l}\text { Cedar } \\
\text { Creek near } \\
\text { Wise Lake }\end{array}$ & $\begin{array}{l}\text { Toms } \\
\text { Creek }\end{array}$ & $\begin{array}{c}\text { Coosawhatchie } \\
\text { River } \\
\text { reference site }\end{array}$ \\
\hline $\begin{array}{l}\text { Contribution (percent of total } \\
\text { organisms) of the numerically } \\
\text { dominant taxon }\end{array}$ & 40 & 40 & 50 & 64 & 39 & 49 \\
\hline EPT/Chironomid abundance ratio & .38 & 1.37 & .18 & .04 & .81 & .35 \\
\hline \multicolumn{7}{|c|}{ Biotic condition scores } \\
\hline $\begin{array}{l}\text { Taxa richness (number of } \\
\text { macroinvertebrate species) }\end{array}$ & na & 6 & 6 & 6 & 6 & 6 \\
\hline EPT index (species $)^{d}$ & na & 6 & 6 & 6 & 6 & 6 \\
\hline EPT/Chironomid abundance ratio ${ }^{\mathrm{e}}$ & na & 6 & 3 & 0 & 6 & 6 \\
\hline Biotic condition score & na & 18 & 15 & 12 & 18 & 18 \\
\hline Percent of reference stream & na & 100 & 83 & 67 & 100 & 100 \\
\hline $\begin{array}{l}\text { Biotic condition category }{ }^{\mathrm{f}} \\
\quad \text { compared with reference stream }\end{array}$ & na & $\begin{array}{l}\text { non- } \\
\text { impaired }\end{array}$ & $\begin{array}{l}\text { non- } \\
\text { impaired }\end{array}$ & $\begin{array}{l}\text { slightly } \\
\text { impaired }\end{array}$ & $\begin{array}{l}\text { non- } \\
\text { impaired }\end{array}$ & reference \\
\hline
\end{tabular}

${ }^{a}$ The Congaree River data are included here because it is one of the streams in the study area and affects the hydrology of Congaree Swamp. These data should not be compared to data from the other streams because the Congaree River is not a blackwater stream.

${ }^{\mathrm{b}}$ The biotic condition score for taxa richness is based on the ratio of the study site to the reference site times 100 . If the result is greater than 80 percent, the assigned score is 6 ; if the ratio is $40-80$ percent, the assigned score is 3 ; if the ratio is less than 40 percent, the assigned score is 0 .

${ }^{c}$ The biotic condition score for the contribution of the numerically dominant taxon is based on the ratio of the study site to the reference site times 100. If the result is less than 30 percent, the assigned score is 6; if 30-50 percent, the assigned score is 3 ; if greater than 50 percent, the assigned score is 0 .

${ }^{\mathrm{d}}$ The biotic condition score for the EPT index is based on the ratio of the study site to the reference site times 100. If the result is greater than 90 percent, the assigned score is 6 ; if 70-90 percent, the assigned score is 3 ; if less than 70 percent, the assigned score is 0 .

${ }^{\mathrm{e}}$ The biotic condition score for the EPT/Chironomid ratio is based on the ratio of the study site to the reference site times 100 . If the result is greater than 75 percent, the assigned score is 6; if $25-75$ percent, the assigned score is 3 ; if less than 25 percent, the assigned score is 0 .

${ }^{\mathrm{f}}$ The biotic condition scores for each site are summed. The biotic condition category is determined by direct percentage comparison of the biotic condition score with those of the reference stream. The following apply: If the biotic condition score for a stream is greater than 79 percent of that of the reference stream, a biotic condition category of "non-impaired" is assigned; if 54-79 percent, the condition category is "slightly impaired;" 21-50 percent is assigned "moderately impaired;" and less than 17 percent is assigned "severely impaired" (Plafkin and others, 1989). Gaps between categories allow subjective assignment of biotic condition.

Results of the macroinvertebrate density calculations clearly indicate similarities in habitat structure between Myers Creek and Cedar Creek near Wise Lake, and between Cedar Creek and Toms Creek. The high densities in Cedar Creek near Wise Lake and Myers Creek are indicative of the availability of habitat (many woody snags and leaf packs) combined with an organically rich benthic material. The relatively lower densities in Cedar Creek and Toms Creek indicate much less available habitat and reflect the sandy, shifting bottom-material characteristics.

\section{Fishes}

Forty-four species of fishes were collected from five sites in the study area. Cedar Creek is the most diverse stream, with 24 of the 44 species (table 9). The three other small streams are similar to each other in numbers of species: Myers Creek has 15, Toms Creek has 14, and Cedar Creek near Wise Lake has 16 species (Appendix 9). In comparison, the Congaree River at Columbia has 20 species, 14 of which were not collected in any of the other four sites (table 9). Of those 14 species collected only from the Congaree 
Table 9. Fish species identified in streams of Congaree Swamp

[An " $X$ " indicates the species was collected in the stream; species names in bold print were not previously listed as found in streams in the study area]

\begin{tabular}{|c|c|c|c|c|c|c|}
\hline Scientific name & Common name & $\begin{array}{c}\text { Congaree } \\
\text { River at } \\
\text { Columbia }\end{array}$ & $\begin{array}{l}\text { Myers } \\
\text { Creek }\end{array}$ & $\begin{array}{l}\text { Cedar } \\
\text { Creek }\end{array}$ & $\begin{array}{c}\text { Cedar } \\
\text { Creek } \\
\text { near Wise } \\
\text { Lake }\end{array}$ & $\begin{array}{l}\text { Toms } \\
\text { Creek }\end{array}$ \\
\hline Ameiurus natalis & yellow bullhead & & $\mathrm{X}$ & $\mathrm{X}$ & & $\mathrm{X}$ \\
\hline Ameiurus nebulosus & brown bullhead & & & $x$ & & \\
\hline Amia calva & bowfin & $x$ & & & $\mathrm{x}$ & \\
\hline Aphredoderus sayanus & pirate perch & & $x$ & & $x$ & \\
\hline Carpiodes carpio & river carpsucker & $\mathrm{x}$ & & & & \\
\hline Carpiodes cyprinus & quillback & $\mathrm{x}$ & & & & \\
\hline Ctenopharyngodon idella & grass carp & $x$ & & & & \\
\hline Cyprinella nivea & whitefin shiner & $\mathrm{x}$ & & & & \\
\hline Cyprinus carpio & common carp & $\mathrm{x}$ & & & & \\
\hline Dorosoma cepedianum & gizzard shad & $x$ & & & & \\
\hline Dorosoma petenense & threadfin shad & $x$ & & & & \\
\hline Enneacanthus chaetodon & blackbanded sunfish & & $x$ & $x$ & & \\
\hline Enneacanthus gloriosus & bluespotted sunfish & & & $x$ & & \\
\hline Erimyzon oblongus & creek chubsucker & & & & & $\mathrm{x}$ \\
\hline Esox americanus & redfin pickerel & & $x$ & & & $x$ \\
\hline Esox niger & chain pickerel & & & $x$ & $x$ & $x$ \\
\hline Etheostoma olmstedi & tessellated darter & & $x$ & $x$ & $x$ & \\
\hline Gambusia holbrooki & eastern mosquito fish & & $x$ & $x$ & & $x$ \\
\hline Ictalurus furcatus & blue catfish & $x$ & & & & \\
\hline Ictalurus punctatus & channel catfish & $x$ & & & & \\
\hline Labidesthes sicculus & brook silverside & & $x$ & $x$ & $x$ & \\
\hline Lepisosteus osseus & longnose gar & $x$ & & & & \\
\hline Lepomis auritus & redbreast sunfish & $x$ & $\mathrm{x}$ & $x$ & $x$ & $x$ \\
\hline Lepomis gulosus & warmouth & & $x$ & $x$ & $x$ & $x$ \\
\hline Lepomis macrochirus & bluegill & $x$ & $x$ & $x$ & $x$ & $x$ \\
\hline Lepomis marginatus & dollar sunfish & & $x$ & $x$ & $x$ & $x$ \\
\hline Lepomis microlophus & redear sunfish & & & & $x$ & \\
\hline Lepomis punctatus & spotted sunfish & & $x$ & $x$ & & $x$ \\
\hline Lepomis sp. & sunfish hybrid & & & $x$ & & \\
\hline Micropterus salmoides & largemouth bass & $x$ & & $x$ & $x$ & \\
\hline Minytrema melanops & spotted sucker & $x$ & $x$ & $x$ & $x$ & $x$ \\
\hline Morone americana & white perch & $x$ & & & & \\
\hline Morone saxatilis & striped bass & $x$ & & & & \\
\hline Moxostoma anisurum & silver redhorse & $x$ & & & & \\
\hline Notropis cummingsae & dusky shiner & & & $x$ & & $\mathrm{x}$ \\
\hline Notropis petersoni & coastal shiner & & $x$ & $x$ & $x$ & \\
\hline Noturus gyrinus & tadpole madtom & & & $x$ & & \\
\hline Noturus insignis & margined madtom & & & $x$ & $x$ & \\
\hline Noturus leptacanthus & speckled madtom & & & $x$ & & \\
\hline Perca flavescens & yellow perch & $x$ & $x$ & $x$ & $x$ & $x$ \\
\hline Percina crassa & piedmont darter & & & $x$ & & \\
\hline Pomoxis annularis & white crappie & $\mathrm{x}$ & & & & \\
\hline Pomoxis nigromaculatis & black crappie & & & & $x$ & \\
\hline Pteronotropis hypselopterus & sailfin shiner & & & $x$ & & $x$ \\
\hline Total species & & 20 & 15 & 24 & 16 & 14 \\
\hline
\end{tabular}


River, some are fish that are generally adapted to open, deep water and would not fare well in the shallow water of the smaller streams. One might expect the common carp and the longnose gar to occasionally travel to the smaller streams, but none were collected in this survey.

The collection made during this study includes four species not previously listed as inhabitants of Congaree Swamp National Monument streams (National Park Service, 1996; Bulak and others, 1997). These species are the brown bullhead (Ameiurus nebulosus), the speckled madtom (Noturus leptacanthus), the piedmont darter (Percina crassa), and the sailfin shiner (Pteronotropis hypselopterus; table 9).

Cedar Creek has the highest density of fish fauna of the four streams (fig. 14). The catch per unit effort (CUE) in Cedar Creek was 20 fishes per 5 minutes of electric-power application to the water. Toms Creek yielded the next highest CUE with 17 fishes per 5 minutes, and Myers Creek and Cedar Creek near Wise Lake yielded 8 and 3, respectively, per 5 minutes of electric-power application.
The relatively low yield from Cedar Creek near Wise Lake most likely was the result of low specific conductance and deeper water. When specific conductance is low, the efficiency of power fishing also is low. In combination with deeper water (allowing less light penetration and poor visibility), the CUE is expected to be low. Boat shocking, barge shocking, and backpack shocking efforts yielded equally poor results. Attempts to collect fishes with a seine were unsuccessful because of the large number of woody snags in the stream. Other collection methods, such as the application of rotenone, were not within the scope of the collection permit. It is likely that more species are in Cedar Creek near Wise Lake than were collected in this study.

The Congaree River presented a collection challenge. An 18-foot electrofishing boat and a chase boat were used for collecting fish. Water depth and current were impediments to fish collection. Efforts were made to collect fish as thoroughly as possible, consistent with crew safety. However, the assessment of water quality based on fish in the Congaree River at

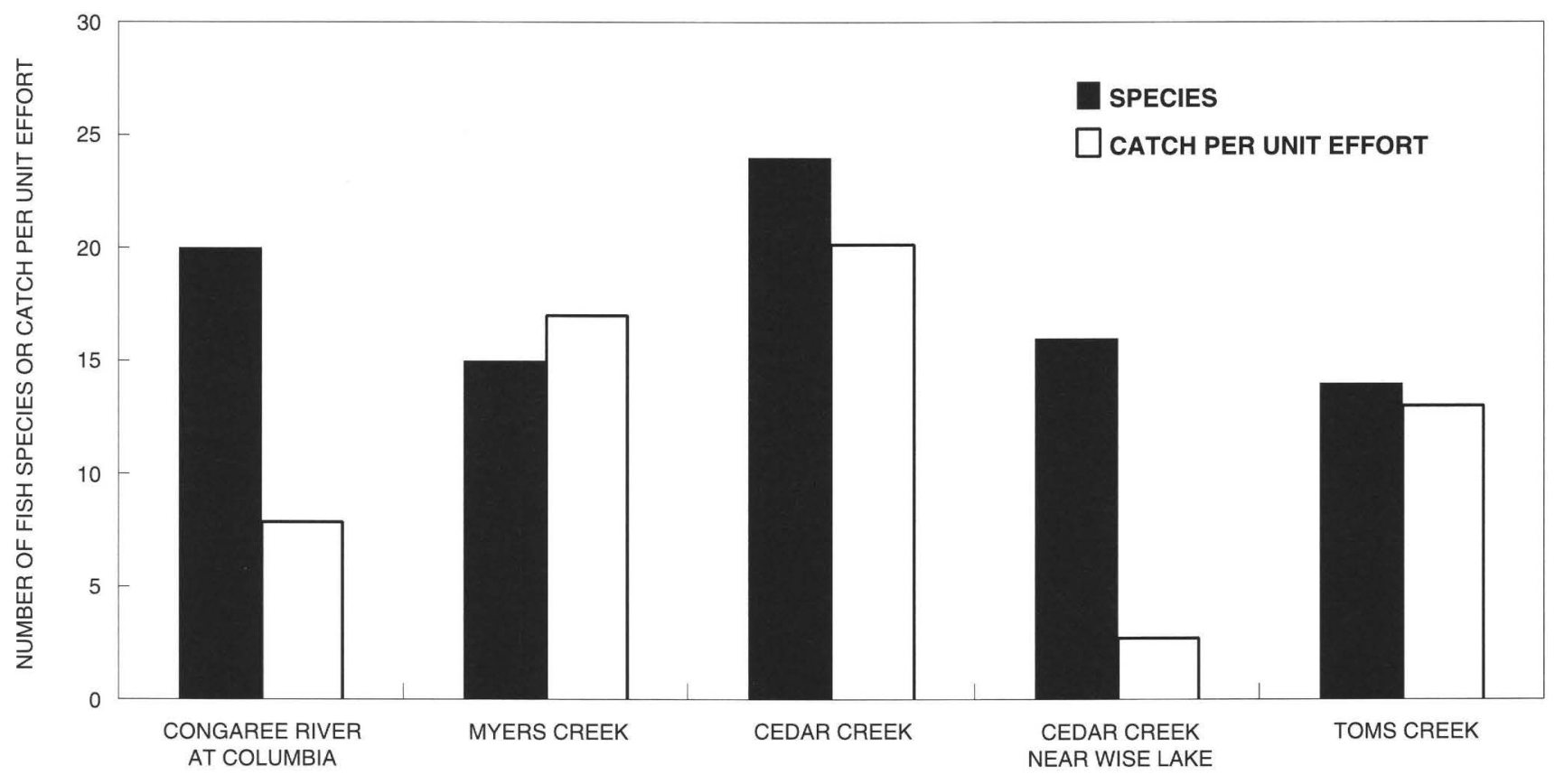

Figure 14. Fish species diversity and catch per unit effort in streams of Congaree Swamp. 
Columbia should be considered tentative at this time. A seine was employed as a backup collection device, but yielded no fish. Fish fauna in Myers Creek, Cedar Creek, and Toms Creek are believed to have been adequately represented.

An index of biotic integrity (IBI) was calculated for each of the streams. The IBI is a fish community assessment procedure developed by Karr (1981) and modified to reflect regional differences in fish communities. The formulas used in this study were patterned after work conducted in South Carolina (South Carolina Department of Health and Environmental Control, 1993). The IBI calculations are based on the perspectives of zoogeography, ecosystem, population, community, taxonomy, and trophic level. Each stream is assigned a score based on the metrics (quantitative and qualitative measures) determined from the results of the fish collections. A general description of water quality, ranging from "very poor" to "excellent," is assigned within a range of metric scores. The fish IBI scores for Congaree Swamp streams are listed in table 10. Computations of the IBI scores are in Appendix 10.

Table 10. Fish indices of biotic integrity (IBI) in streams of Congaree Swamp

[Range of descriptors for IBI score: 12-28, very poor; 29-40, poor; 41-48, fair; 49-58, good; greater than 58, excellent]

\begin{tabular}{lcc}
\hline \multicolumn{1}{c}{ Stream } & $\begin{array}{c}\text { Fish } \\
\text { IBI } \\
\text { score }\end{array}$ & $\begin{array}{c}\text { Water- } \\
\text { quality } \\
\text { description }\end{array}$ \\
\hline Congaree River at Columbia & 34 & Poor \\
Myers Creek & 38 & Poor \\
Cedar Creek & 44 & Fair \\
Cedar Creek near Wise Lake & 34 & Poor \\
Toms Creek & 40 & Poor \\
\hline
\end{tabular}

The results of the fish IBI are comparable with the results of the macroinvertebrate biotic condition scores. Both scoring methods evaluate the water quality in Cedar Creek near Wise Lake as being somewhat impaired. The macroinvertebrate scores single out Cedar Creek near Wise Lake as the only impaired stream compared to the Coosawhatchie River, the reference site. The fish scores evaluate Cedar Creek near Wise Lake as "poor," but also include the
Congaree River, Myers Creek, and Toms Creek in the "poor" category. Cedar Creek is indicated as "fair," based on the fish IBI, and as "non-impaired," based on the macroinvertebrate biotic condition score. The differences in sensitivity and results between the two methods reflect the need for fine-tuning based on the characteristics of the streams. Both measurements failed to identify Myers Creek as being impaired, which might have been the conclusion based solely on the chemical evidence, specifically the organic compounds.

Although pesticides were detected most often in Myers Creek (28 detections), it should not be deduced solely from the chemical evidence that harmful biological effects would be detected at that site. A basic principle of environmental toxicology states that the bioavailability of toxic substances, not merely their concentration, is the cause of toxicity. As long as pesticide concentrations in Myers Creek do not reach toxic threshold levels, they should not cause toxic effects to aquatic organisms. Only through toxicological and other biological investigations can toxic effects be asserted. Because of the complementary/supplementary roles of chemical and biological analyses, it is a tremendous advantage to employ both for complex aquatic environmental assessment.

\section{Ecology and Water Quality}

The water-quality constituents that have the greatest relation to the macroinvertebrate community in streams of the study area, as determined by a Pearson correlation analysis, are dissolved oxygen concentration, water temperature, and chloride concentrations. The correlations are significant at $\alpha=0.05$. Macroinvertebrate community diversity is positively correlated with the concentration of chloride dissolved in the water column $\left(\mathrm{r}^{2}=0.78\right)$. The EPT index is negatively correlated with temperature $\left(r^{2}=0.83\right)$, and the density of Chironomids is negatively correlated with dissolved oxygen $\left(\mathrm{r}^{2}=0.93\right)$. Water column pesticide concentrations in Myers Creek, Cedar Creek, Cedar Creek near Wise Lake, and Toms Creek have no discernible detrimental effects on the aquatic communities in these streams.

\section{Tissue}

Tissue samples were collected using NAWQA protocols. Samples were collected in an effort to 
characterize the distribution and magnitude of organochlorine pesticides and certain trace elements in aquatic biota.

\section{Pesticides in Fish}

Redbreast sunfish (Lepomis auritus) was the organism chosen for tissue pesticide analysis in Myers Creek, Cedar Creek, and Toms Creek. Fishes were collected by power-fishing techniques. After several attempts, no redbreast sunfish were caught at Cedar Creek near Wise Lake.

The only organochlorine pesticide detected in the tissues of sunfish collected for this study was $p, p^{\prime}$-DDE, a metabolic derivative of DDT. This compound is less toxic than DDT but is highly recalcitrant, lingering in the environment for many years. The highest concentration (16 micrograms per kilogram $[\mu \mathrm{g} / \mathrm{kg}]$ ) was in fishes from Cedar Creek. Tissues from sunfishes in Toms Creek had a concentration of $10 \mu \mathrm{g} / \mathrm{kg}$, and Myers Creek sunfish tissues had a concentration of $5.1 \mu \mathrm{g} / \mathrm{kg}$ (fig. 15). The effect, if any, of the presence of these pesticides on the fish is not known.
Fish tissue at the Congaree River at Columbia site consisted of whole-body carp. Several pesticides were detected in carp that were not detected in the redbreast sunfish in the other streams. In addition to $p, p^{\prime}$-DDD and $p, p^{\prime}$-DDE, Congaree River carp tissue contained concentrations of chlordane and nonachlor compounds and dieldrin. Chlordane is a persistent, manmade pesticide that is highly toxic to fish and invertebrates. Chlordane has not been used legally in the United States since 1988. Nonachlor is a metabolite of chlordane. Dieldrin was widely used in the 1960's and early 1970's as a soil and seed treatment. It has not been used legally in the United States since 1974. Concentrations of organochlorine pesticides detected in all fish tissue samples are listed in Appendix 11. A direct comparison between carp and redbreast sunfish cannot be made because of differences in species, behavior, and habitat.

\section{Pesticides in Clams}

Native clams were collected from only one of the six sites; a sandbar downstream from the confluence of Cedar and Myers Creeks yielded several specimens of

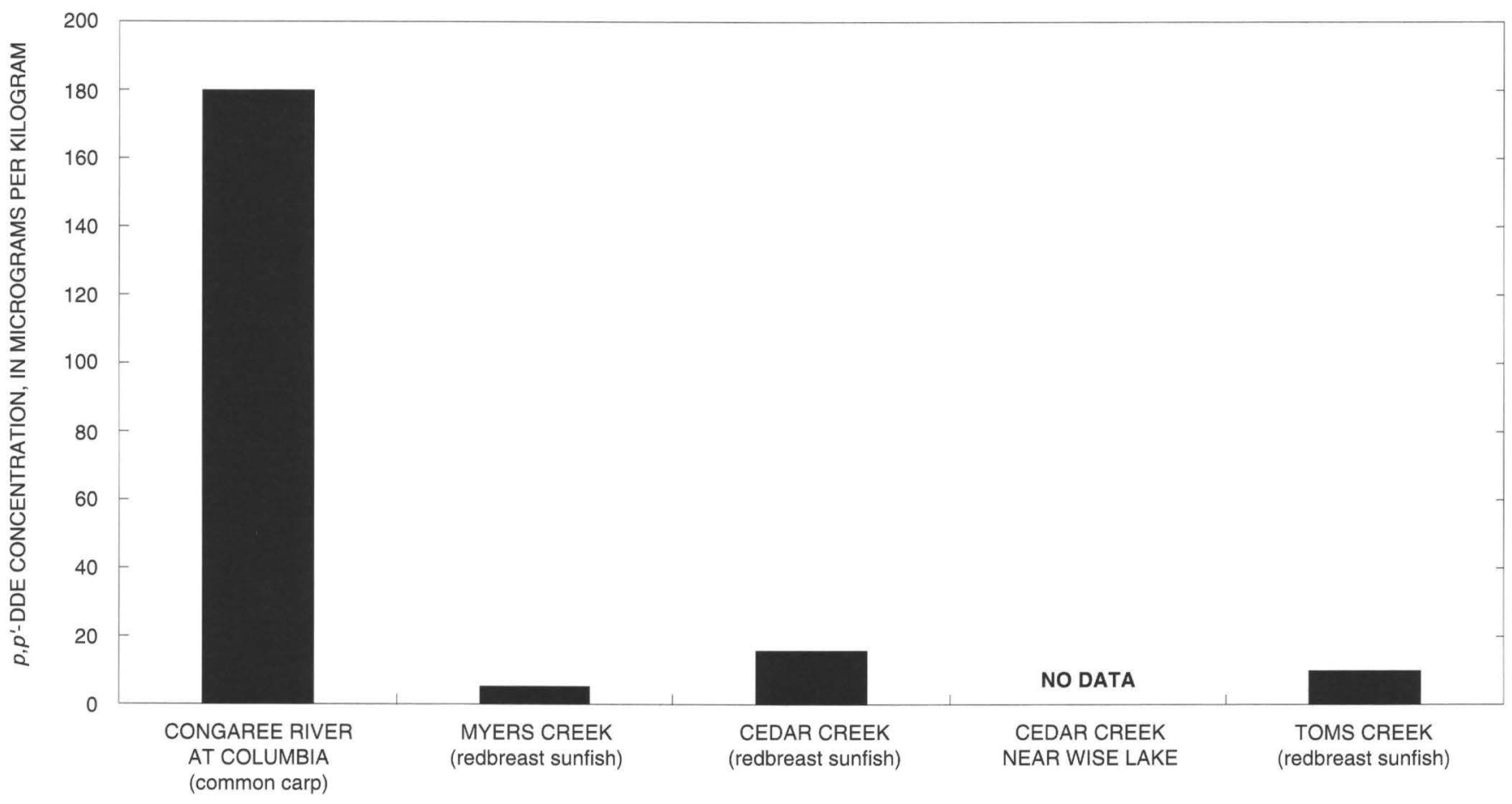

Figure 15. $p, p^{\prime}-\mathrm{DDE}$ detected in fish tissue collected in streams of Congaree Swamp. 
Elliptio sp. No pesticides were detected in the tissues of these native clams. Pesticides in Asiatic clams collected from the Congaree River sites were $p, p^{\prime}$-DDE and cis-Chlordane. Appendix 11 provides a complete list of the 26 pesticides for which clam (and fish) tissues were analyzed.

\section{Trace and Major Elements in Fish}

Fishes were not a viable source for the analysis of elements in tissue from any of the streams except the Congaree River. The NAWQA protocols stipulate the use of fish livers for element analysis. No fishes were collected that were large enough to enable extracting an adequate amount of liver tissue for analysis. Attempts to capture the common carp (Cyprinus carpio) were unsuccessful, although it has been included in the species listing for Congaree Swamp (National Park Service, 1996). Congaree River carp liver tissue was analyzed for trace and major elements. Of the nine trace-element priority pollutants, zinc was detected in the highest concentration. The data indicate that carp have accumulated zinc to a concentration almost six times that of the sediments, and copper to a concentration more than twice that in sediments. The full data set is provided in Appendix 12 .

\section{Trace and Major Elements in Clams}

Native bivalve clams (Elliptio sp.) were collected in Cedar Creek immediately downstream from the confluence with Myers Creek. Clam tissue was analyzed for 21 elements. Among the nine traceelement priority pollutants, zinc $(62 \mu \mathrm{g} / \mathrm{g})$, lead $(22 \mu \mathrm{g} / \mathrm{g})$, and cadmium $(5 \mu \mathrm{g} / \mathrm{g})$ were present in the highest concentrations. No criteria currently exist for the protection of aquatic life that are based on traceelement concentrations in clam tissue.

\section{Bed Sediments}

Bed-sediment samples were collected from the top few centimeters of sediment at several sites in each stream in the study area in order to determine the magnitude and extent of the distribution of organic compounds, and trace and major elements in the study area. Sediment-bound pesticides appeared to have no significant effect on the macroinvertebrate and fish communities in these streams.

\section{Organochlorine Pesticides}

Mirex was the only non-DDT pesticide detected in samples collected from the four streams in the study area, and was detected only in Myers Creek $(1.2 \mu \mathrm{g} / \mathrm{kg})$. Mirex had been used to control fire ants in the Southeastern United States and as a fire-retardant in polymers. Mirex has low chemical reactivity, is resistant to biodegradation, and is strongly sorbed onto bacteria, algae, and sediments.

The pesticide DDT and its metabolites were the only other organochlorine pesticides detected in the sediments of the four streams (fig. 16; table 11; Appendix 13). DDT is an extremely effective, longlasting pesticide that was officially banned from use in the United States in January 1973 (Laws, 1993). Myers Creek contained the highest concentrations of DDT and its metabolites (in sum, $14.7 \mu \mathrm{g} / \mathrm{kg}$ ), with $p, p$-DDE accounting for 66 percent of that amount. In contrast, the bed-sediment sample from the right bank of the Congaree River at Columbia contained traces of chlordane, dieldrin, and nonachlor. Chlordane and dieldrin belong to the same class of organic compounds and have been widely used to control termites and a variety of food crop pests. 


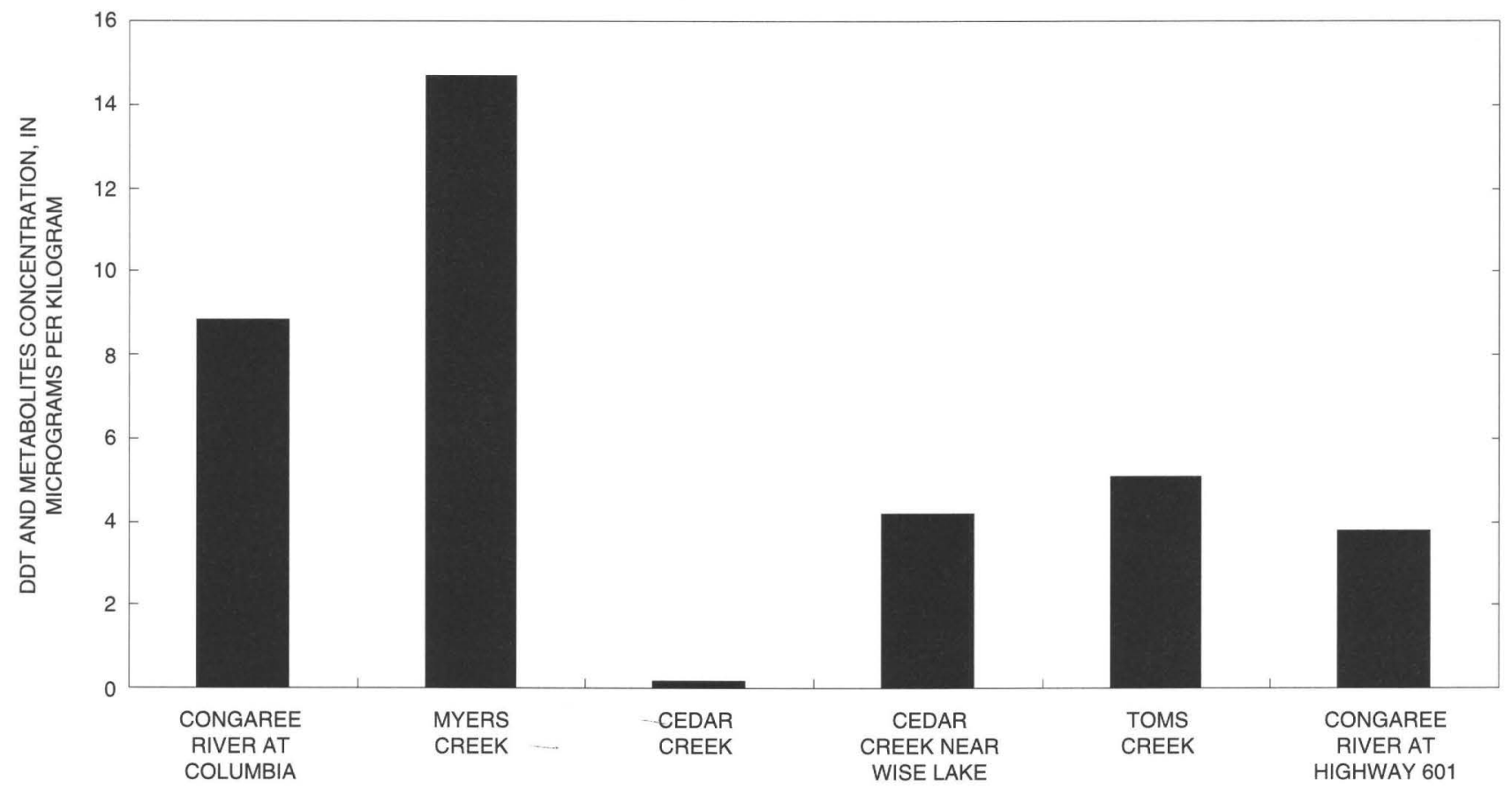

Figure 16. DDT and metabolites detected in bed sediments of streams of Congaree Swamp. (Concentration shown for Congaree River at Columbia is median value from left bank and right bank collection sites.)

Table 11. Bed-sediment organochlorine pesticides

[Units in micrograms per kilogram; nd, not detected]

\begin{tabular}{|c|c|c|c|c|c|c|c|}
\hline Pesticide & $\begin{array}{l}\text { Congaree } \\
\text { River at } \\
\text { Columbia } \\
\text { (left bank) }\end{array}$ & $\begin{array}{c}\text { Congaree } \\
\text { River at } \\
\text { Columbia } \\
\text { (right bank) }\end{array}$ & $\begin{array}{l}\text { Myers } \\
\text { Creek }\end{array}$ & $\begin{array}{l}\text { Cedar } \\
\text { Creek }\end{array}$ & $\begin{array}{c}\text { Cedar Creek } \\
\text { near Wise } \\
\text { Lake }\end{array}$ & $\begin{array}{l}\text { Toms } \\
\text { Creek }\end{array}$ & $\begin{array}{c}\text { Congaree } \\
\text { River at } \\
\text { Highway } 601\end{array}$ \\
\hline DDT and metabolites & 9.3 & 8.4 & 14.7 & 0.17 & 4.2 & 5.1 & 3.8 \\
\hline trans-Chlordane & nd & .62 & nd & nd & nd & nd & nd \\
\hline cis-Chlordane & nd & .64 & nd & nd & nd & nd & nd \\
\hline Dieldrin & nd & .51 & nd & nd & nd & nd & nd \\
\hline Mirex & nd & nd & 1.2 & nd & nd & nd & nd \\
\hline trans-Nonachlor & nd & .47 & nd & nd & nd & nd & nd \\
\hline
\end{tabular}




\section{Non-Pesticide Organic Compounds}

Forty-one non-pesticide organic compounds were detected in sediment samples from the six sites. The most common compounds detected were semivolatile organic compounds, phthalate compounds, fluoranthene, and pyrene compounds (Appendix 14). The sum of all non-pesticide organic compounds was highest in Myers Creek with four to five times as much as was detected in Cedar Creek, Cedar Creek near Wise Lake, or Toms Creek. A summation of the non-pesticide organic compounds detected in the sediments of each of the six streams is shown in figure 17.

The major components of non-pesticide organic compounds in Myers Creek were benzo[a]pyrene $(570 \mu \mathrm{g} / \mathrm{kg})$, fluoranthene $(340 \mu \mathrm{g} / \mathrm{kg}), p$-cresol (260 $\mu \mathrm{g} / \mathrm{kg})$, bis(2-ethylhexyl) phthalate $(260 \mu \mathrm{g} / \mathrm{kg})$, and pyrene $(200 \mu \mathrm{g} / \mathrm{kg}$; table 12$)$. Benzo[a]pyrene, a polycyclic aromatic hydrocarbon $(\mathrm{PAH})$, is a ubiquitous contaminant that is generated by the incomplete combustion of many substances, such as gasoline in internal combustion engines. Its effect, if any, on the aquatic life in Myers and Cedar Creeks is unknown. The other PAH's detected were fluoranthene and pyrene (fig. 18).

Para-cresol ( $p$-cresol) is representative of the general class of phenolic compounds. It enters the environment as a by-product of the petroleum and coking industry and as a result of the use of creosote as a wood preservative, such as creosote-soaked pilings used for bridge structures. It is a relatively nonhazardous, easily biodegradable material and poses little threat to aquatic life at the concentrations detected in Myers Creek.

Bis(2-ethylhexyl) phthalate is used as a plasticizer in polyvinyl chloride resins (PVC) used in the manufacture of a wide range of vinyl products, such as enclosures for food containers, children's toys, teething rings, and pacifiers. Bis(2-ethylhexyl) phthalate is used as an ink solvent, an inert ingredient in pesticides, and in cosmetic products (National Safety Council, 1999). Phthalates are ubiquitous in the environment. The concentrations detected in Myers Creek sediments are well within the estimated range of daily per capita human consumption (U.S. Environmental Protection Agency, 1998).

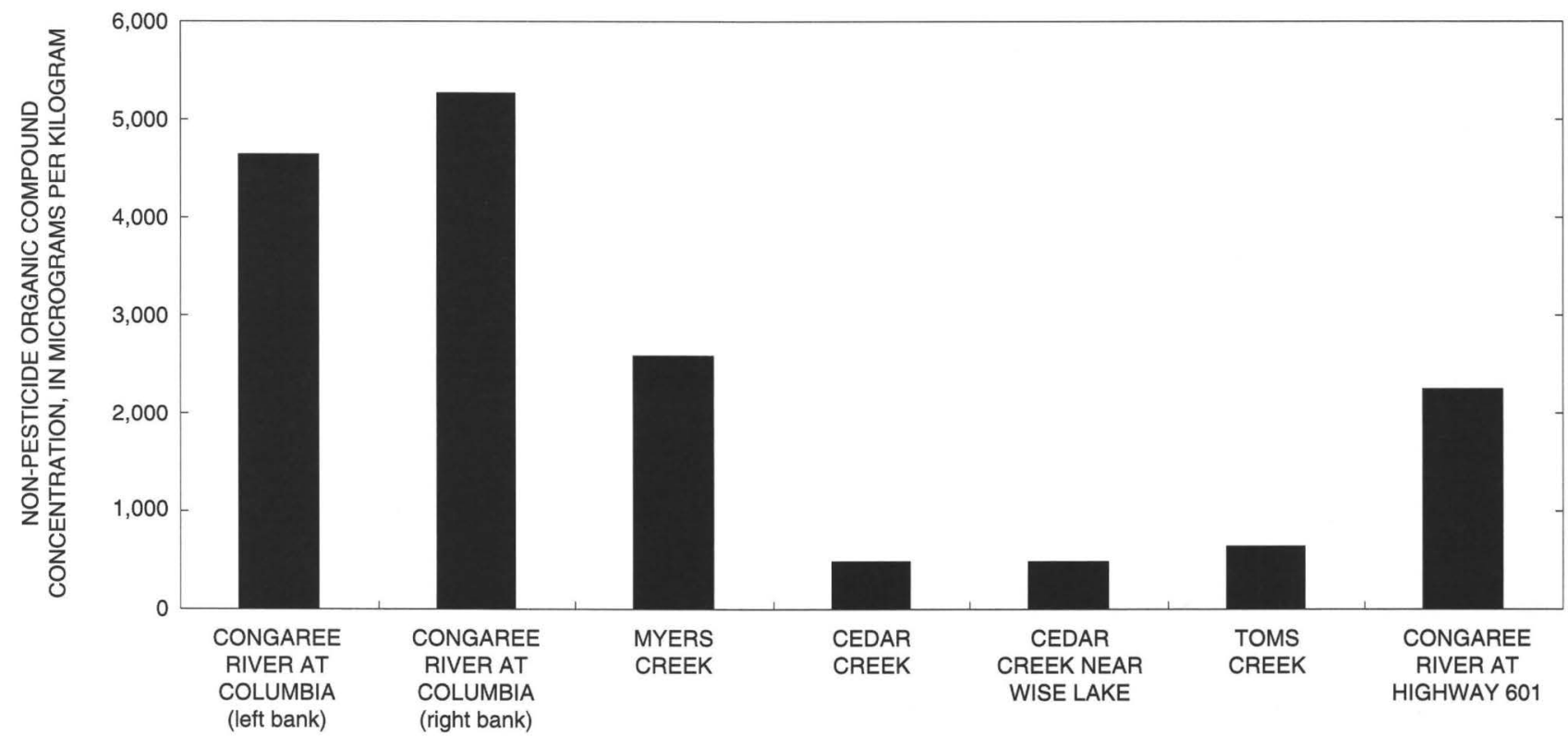

Figure 17. Summation of non-pesticide organic compounds detected in bed sediments of streams of Congaree Swamp. 


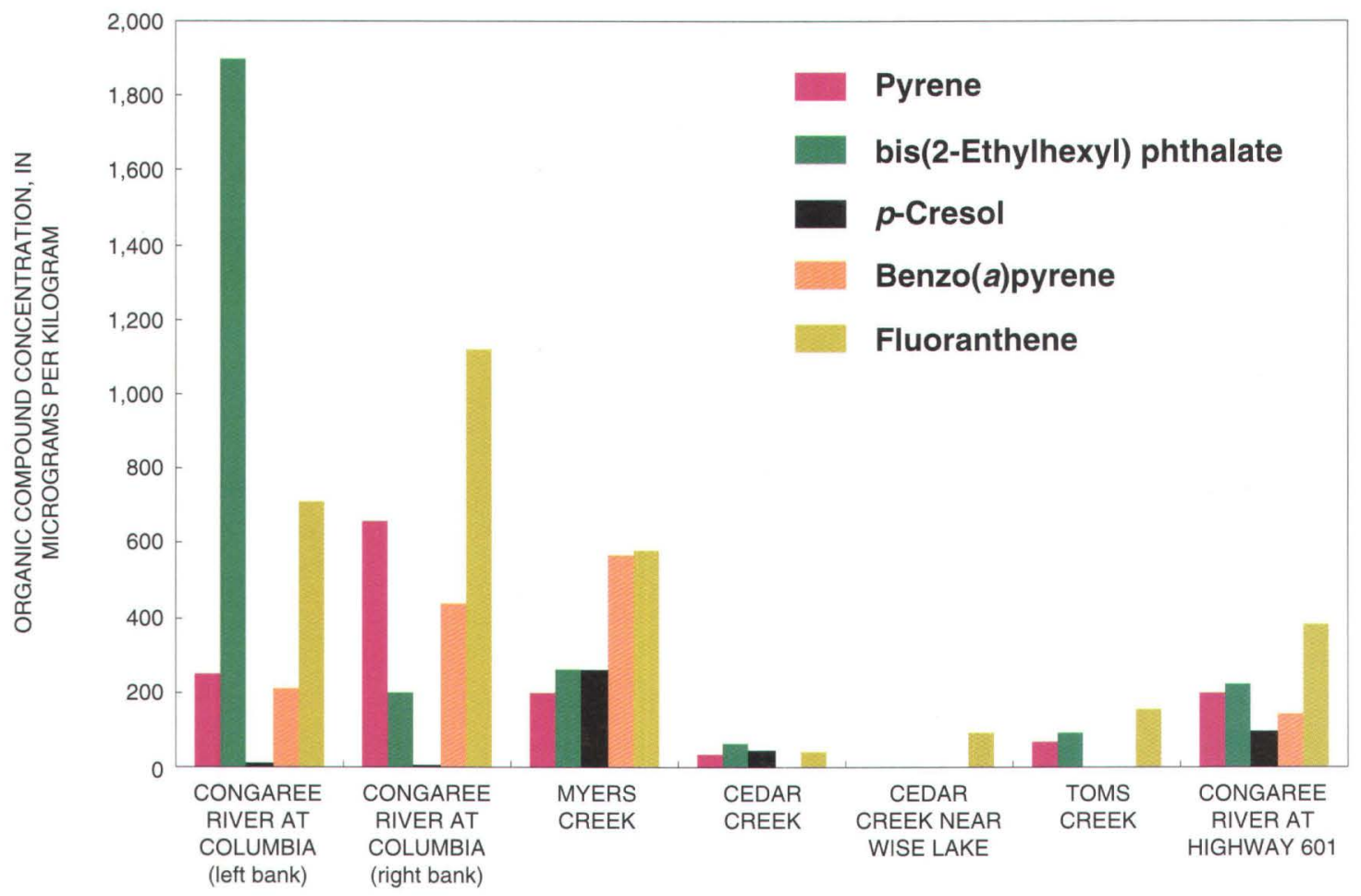

Figure 18. Selected non-pesticide organic compounds in bed sediments of streams of Congaree Swamp.

The relatively high concentrations of the five compounds (listed above) in Myers Creek sediments may be indicative of the greater urbanization of the Myers Creek Basin compared to Cedar Creek or Toms Creek. These five compounds were among the most frequently detected in other studies around the country. Table 12 shows the comparison of concentrations of the five compounds in Myers Creek bed sediments with mean, median, and maximum values from sediments collected by NAWQA studies throughout the country (Lopes and others, 1998).

Analyses of the data and correlation with ecological information indicate that none of the nonpesticide organic compounds detected in sediments has a discernible detrimental effect on the aquatic communities of the streams. Two compounds are positively correlated with the diversity of the macroinvertebrate community (1-methylphenanthrene

Table 12. Semivolatile organic compounds in Myers Creek bed sediments compared to the national data base

[Concentrations in microgram per kilogram; PAH, polycyclic aromatic hydrocarbon]

\begin{tabular}{llcccc}
\hline \multicolumn{1}{c}{ Compound } & $\begin{array}{c}\text { Class } \\
\text { of } \\
\text { compound }\end{array}$ & $\begin{array}{c}\text { National } \\
\text { mean } \\
\text { concentration }^{\text {a }}\end{array}$ & $\begin{array}{c}\text { National } \\
\text { median } \\
\text { concentration }^{\text {a }}\end{array}$ & $\begin{array}{c}\text { National } \\
\text { maximum } \\
\text { concentration }^{\text {a }}\end{array}$ & $\begin{array}{c}\text { Myers Creek } \\
\text { concentration }^{-}\end{array}$ \\
\hline Pyrene & PAH & 501 & 77 & 1,095 & 200 \\
bis $(2$-Ethylhexyl) phthalate & Phthalate & 304 & 75 & 17,000 & 260 \\
$p$-Cresol & Phenol & 199 & 51 & 3,500 & 260 \\
Benzo $[a]$ pyrene & PAH & 357 & 96 & 9,900 & 570 \\
Fluoranthene & PAH & 531 & 49 & 9,000 & 340 \\
\hline
\end{tabular}

${ }^{a}$ Lopes and others, 1998. 
and $4 \mathrm{H}$-cyclopenta[ $[d, e, f]$ phenanthrene), but the reason is not known.

\section{Trace and Major Elements}

Bed sediments were analyzed for 43 trace and major elements (Appendixes 15, 16). Trace elements are defined as those that usually occur in concentrations less than 1,000 micrograms per gram $(\mu \mathrm{g} / \mathrm{g}$; Forstner and Wittmann, 1979). The concentrations of major elements usually are depicted in terms of percent. Among the four smallest Congaree Swamp streams, the major elements present in the highest percentages of concentrations in sediments included aluminum (7 to 12 percent) and iron ( 2.5 to 4.0 percent). Trace elements present in the highest concentrations included manganese (580 to
$1,900 \mu \mathrm{g} / \mathrm{g}$ ), barium (320 to $560 \mu \mathrm{g} / \mathrm{g}$ ), cerium (81 to $140 \mu \mathrm{g} / \mathrm{g}$ ), and zinc (59 to $140 \mu \mathrm{g} / \mathrm{g}$ ).

\section{Trace Element Priority Pollutants}

Nine of 43 trace and major elements for which sediment samples were analyzed in Congaree Swamp streams have been designated as priority pollutants by the U.S. EPA (1996; fig. 19). Sediment concentrations of trace element priority pollutants were not significantly different $(\alpha=0.05)$ from those in sediments from six other South Carolina Coastal Plain or geographically proximate streams of similar size (Abrahamsen, 1999). Adjusted bed-sediment concentrations in the streams are listed in table 13 along with Canadian Government-derived threshold effect levels (TEL's). These TEL's are based on the fraction of the bed-sediment sample that is less than

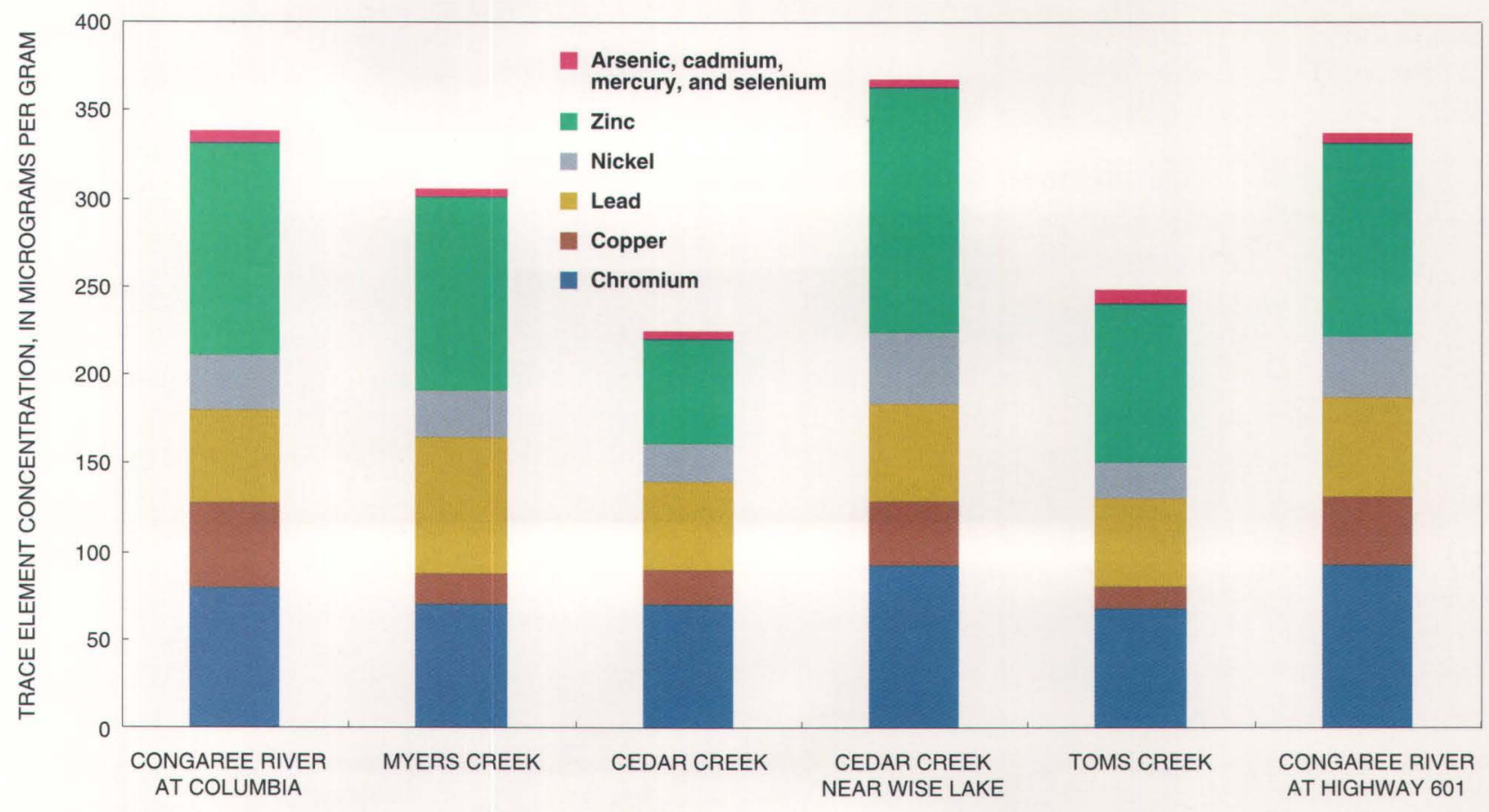

Figure 19. Trace element priority pollutants in bed sediments of streams of Congaree Swamp. 
Table 13. Trace element priority pollutant concentrations in bed sediments of streams of Congaree Swamp and Canadian threshold effect levels for the protection of aquatic life

[Adjusted by percentage of suspended sediment less than 0.062 millimeters in diameter; concentrations in micrograms per gram; - , not established; data on suspended sediment in Congaree River at Highway 601 are not available]

\begin{tabular}{lcccccc}
\hline Element & $\begin{array}{c}\text { Canadian } \\
\text { threshold effect } \\
\text { level }\end{array}$ & $\begin{array}{c}\text { Congaree River } \\
\text { at Columbia } \\
\text { (adjusted) }\end{array}$ & $\begin{array}{c}\text { Myers Creek } \\
\text { (adjusted) }\end{array}$ & $\begin{array}{c}\text { Cedar Creek } \\
\text { (adjusted) }\end{array}$ & $\begin{array}{c}\text { Cedar Creek } \\
\text { near Wise Lake } \\
\text { (adjusted) }\end{array}$ & $\begin{array}{c}\text { Toms Creek } \\
\text { (adjusted) }\end{array}$ \\
\hline Arsenic & 5.9 & 1.1 & 2.5 & 2.5 & 2.8 & 4.3 \\
Cadmium & .596 & .08 & .48 & .21 & .39 & .26 \\
Chromium & 37 & 15 & 56 & 50 & 72 & 45 \\
Copper & 36 & 9 & 14 & 14 & 29 & 9 \\
Lead & 35 & 14 & 61 & .13 & .42 & 33 \\
Mercury & .174 & .02 & .13 & .08 & .08 & .08 \\
Nickel & 18 & 6 & 22 & 16 & 31 & 13 \\
Selenium & - & .18 & .72 & .78 & .55 & .59 \\
Zinc & 123 & 26 & 88 & 42 & 110 & 58 \\
\hline
\end{tabular}

$63 \mu \mathrm{m}$ in diameter. The table contains worst-case scenarios developed from data collected pertaining to the diameter of suspended sediment in the water column. The reported trace element priority pollutant concentrations are based on the percentage of suspended sediment reported as less than $0.062 \mathrm{~mm}$ in diameter. The resultant adjusted concentrations are artificial and can only indicate potential threat to aquatic biota. They are presented here only for comparative purposes. Among the four smallest Congaree Swamp streams (after adjustment), bed sediments in Toms Creek had the highest concentration of arsenic ( $4.3 \mu \mathrm{g} / \mathrm{g}$; table 13). Bed sediments in Cedar Creek near Wise Lake contained the highest concentrations of chromium $(72 \mu \mathrm{g} / \mathrm{g})$, nickel $(31 \mu \mathrm{g} / \mathrm{g})$, and zinc $(110 \mu \mathrm{g} / \mathrm{g})$. Myers Creek bed sediments had the highest concentrations of cadmium $(0.48 \mu \mathrm{g} / \mathrm{g})$, lead $(61 \mu \mathrm{g} / \mathrm{g})$, and mercury $(0.13 \mu \mathrm{g} / \mathrm{g})$.

Among the nine trace element priority pollutants in the sediments and native clam tissues of Cedar
Creek, only cadmium was found in a significantly higher concentration in clam tissues $(5.1 \mu \mathrm{g} / \mathrm{g})$ than in sediments $(0.21 \mu \mathrm{g} / \mathrm{g}$; fig. 20). These findings suggest that native clams are bioconcentrating cadmium. Higher concentrations of cadmium, selenium, and zinc were detected in Asiatic clams in the Congaree River at Columbia and the Congaree River at Highway 601 than were detected in bed sediments. Criteria are not available for the protection of aquatic life based on the concentration of elements in clam tissue.

The overall summation of the trace element priority pollutants in bed sediments indicated no correlation with the macroinvertebrate community or fish community measurements of the streams. None of the individual trace element priority pollutants correlated significantly with fish community diversity in any stream. However, zinc correlated slightly with macroinvertebrate community diversity $\left(\mathrm{r}^{2}=0.77\right)$, and mercury correlated with the EPT/Chironomid ratio $\left(r^{2}=0.85\right)$. 

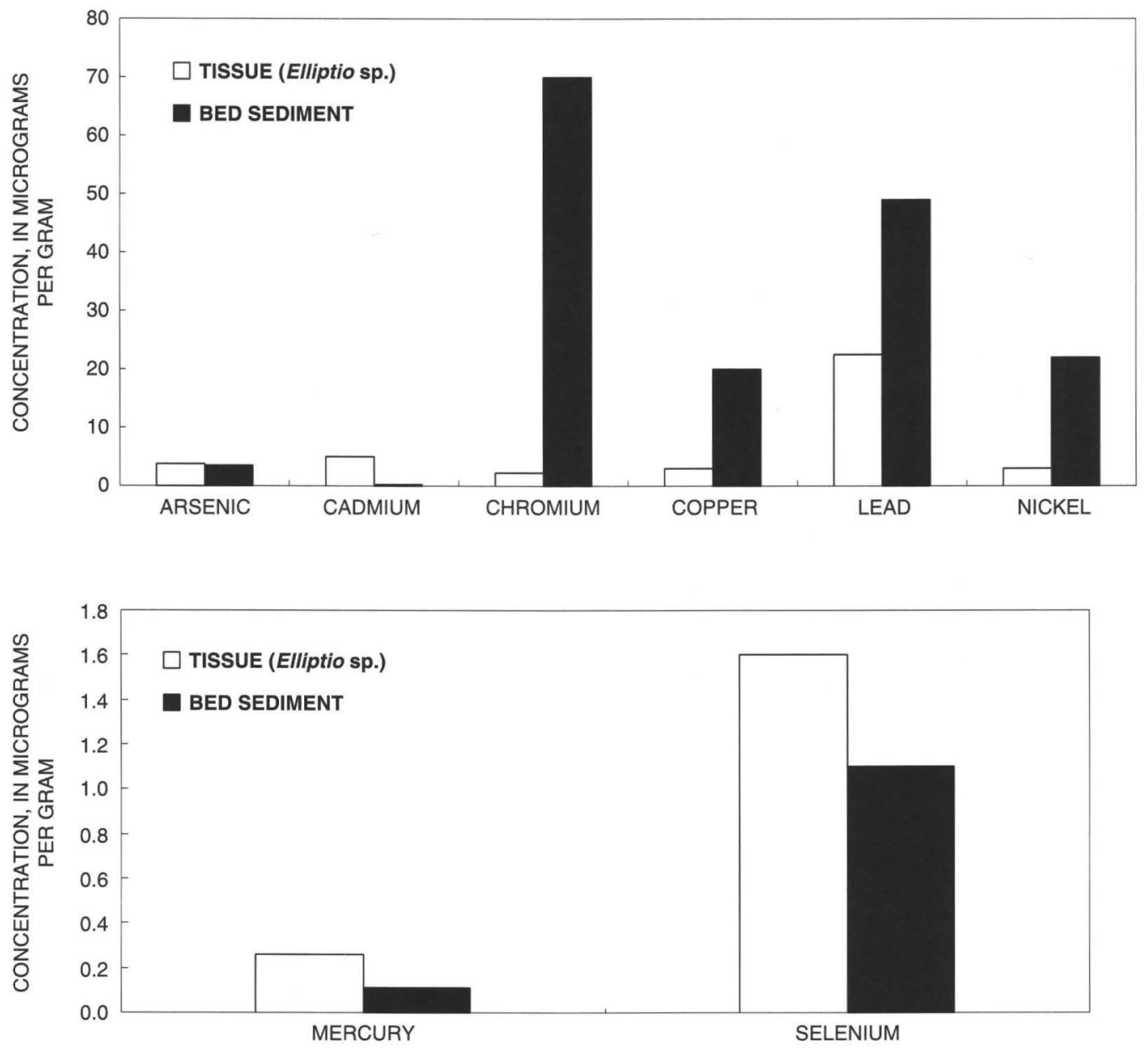

Figure 20. Trace element priority pollutants in clams and bed sediments of Cedar Creek.

\section{SUMMARY}

A study was conducted by the U.S. Geological Survey as part of the National Water-Quality Assessment Program in cooperation with the National Park Service to assess the water quality and ecology of selected streams of Congaree Swamp, South Carolina. Surface-water samples were collected quarterly from January 1996 through September 1998 at four sites-Myers Creek, Cedar Creek, Cedar Creek near Wise Lake, and Toms Creek. In addition, monthly surface-water samples were collected from October 1995 through September 1997 at a site on the Congaree River about $40 \mathrm{~km}$ upstream from Congaree Swamp National Monument. Surface-water samples were analyzed for major ions, nutrients, organic carbon, pesticides, and field-measured constituents (specific conductance, $\mathrm{pH}$, temperature, and dissolved oxygen). Streamflow measurements were made at the time of sampling at the four sites without continuous streamflow gages.

Bed-sediment and tissue samples and aquatic community and habitat data were collected at five of six sites between 1995 and 1998. At a sixth site, Congaree River at Highway 601, only bed-sediment and tissue samples were collected. Samples of bed sediment and tissue were analyzed for organochlorine pesticides and trace and major elements. Sediments also were analyzed for non-pesticide organic compounds. Aquatic community structure and habitat were assessed by the collection of fish, macroinvertebrate fauna, and algae, and the determination of habitat properties, such as stream width, depth, and flow, riparian vegetation, bank stability and structure, and bed substrate composition.

Concentrations of some major ions (calcium, chloride, magnesium, potassium, silica, sodium, and 
sulfate) were significantly higher, whereas other major ions (iron and manganese) were significantly lower in the Congaree River at Columbia than in Myers Creek, Cedar Creek, Cedar Creek near Wise Lake, or Toms Creek. Secondary drinking-water standards for iron (300 micrograms per liter $[\mu \mathrm{g} / \mathrm{L}]$ ) and manganese $(50 \mu \mathrm{g} / \mathrm{L})$ were exceeded in at least one sample at each site. Cedar Creek generally had the lowest and least variable major ion concentrations.

Nutrient concentrations were generally low. Ammonia nitrogen concentrations all were below 0.15 milligrams per liter ( $\mathrm{mg} / \mathrm{L})$, and no significant differences in concentrations were detected among sites. The Congaree River at Columbia had significantly higher concentrations of nitrite-plusnitrate nitrogen than did the other sites, but concentrations were all below $0.5 \mathrm{mg} / \mathrm{L}$. Phosphorus concentrations generally were low, with more variable concentrations in the Congaree River at Columbia than in the other streams. Organic carbon concentrations generally were lower in the Congaree River at Columbia than in the other streams.

Twelve pesticides were detected in the streams of Congaree Swamp. Concentrations ranged from below the method detection limit to a high of $0.084 \mu \mathrm{g} / \mathrm{L}$ for tebuthiuron at Toms Creek. No pesticide exceeded the criteria for the protection of aquatic life or human health.

The Congaree River at Columbia had significantly higher concentrations of suspended sediment than the other streams, and concentrations ranged from 1 to $248 \mathrm{mg} / \mathrm{L}$. Suspended-sediment concentrations in Myers Creek, Cedar Creek, Cedar Creek near Wise Lake, and Toms Creek were all below $30 \mathrm{mg} / \mathrm{L}$. The median percentage of suspended sediment finer than 0.062 millimeters $(\mathrm{mm})$ ranged from about 65 percent to less than 80 percent at all the streams. Specific conductance, alkalinity, and $\mathrm{pH}$ were significantly higher in the Congaree River at Columbia than in the other streams.

Indices of biotic integrity based on fish community diversity and fish density yielded waterquality determinations of "poor" to "fair" for the five sites in which fish were collected. The site with the greatest fish diversity and best water quality ("fair") was Cedar Creek, which supported 24 of the 44 species of fishes collected. Toms Creek had the lowest fish diversity and a water-quality designation of "poor," but the Congaree River at Columbia, Myers Creek, and
Cedar Creek near Wise Lake also were determined to have poor water quality based on fish IBI's.

Determination of biotic condition based on macroinvertebrate community diversity and density indicated that, of the five sites, only Cedar Creek near Wise Lake had impaired water quality when compared with a reference stream (Coosawhatchie River). The density of the macroinvertebrate communities clearly reflected similarities in habitat structure between Myers Creek and Cedar Creek near Wise Lake, and between Cedar Creek and Toms Creek. The biological components of the study failed to single out Myers Creek as an impaired stream even though it may have appeared to be impaired, based solely on the interpretation of the potential effects of the concentrations of organic compounds detected in bed sediments.

Organochlorine pesticides and non-pesticide organic compounds in bed sediments had no discernible detrimental effect on the macroinvertebrate or fish communities in the streams. The sum of the concentrations of trace element priority pollutants in bed sediments did not have a discernible effect on macroinvertebrate diversity, the appearance of a dominant taxon, or the standard indicators of water quality - mayflies, caddisflies, and stoneflies (EPT index). However, the EPT/Chironomid ratio was positively correlated with the concentration of mercury in the sediments $\left(r^{2}=0.85\right)$. A comparison of bedsediment concentrations of the trace element priority pollutants with the Canadian Government threshold effect levels for the protection of aquatic life indicates that lead and nickel in bed sediments could be elements of concern in the Congaree River at Columbia, Myers Creek, and Cedar Creek near Wise Lake. Chromium concentrations in the bed sediments of all streams in the study exceeded the Canadian threshold effect levels. However, the presence of chromium in bed sediments had no discernible deleterious effect on the macroinvertebrate biota of the streams.

Native clams in Cedar Creek, and Asiatic clams in Congaree River at Columbia and in Congaree River at Highway 601 accumulated cadmium and zinc to concentrations greater than those detected in the sediments, but the clams did not accumulate chromium, copper, lead, or nickel.

Comparison of water-quality parameters with ecological data suggests that Chironomid densities are negatively correlated with dissolved oxygen concentrations in the water column. The EPT index 
was positively correlated with the concentration of chlorides in the water column and negatively correlated with water temperature. No correlation was apparent with concentrations of pesticides detected in the water column, and these pesticides had no apparent effect on the aquatic community.

From an ecological view, the character and health of the aquatic communities of the streams of Congaree Swamp appear to be driven and affected more by habitat, dissolved oxygen, and water temperature than by the chemical products and byproducts of human land-use activities.

\section{SELECTED REFERENCES}

Abrahamsen, T.A., 1999, Trace elements in the bed sediment and biota of streams in the Santee River Basin and coastal drainages, North and South Carolina, 1995-97: U.S. Geological Survey Water-Resources Investigations Report 99-4179, in press.

Barton, M.C., and O'Brien-White, S.K., 1995, Fishes of the Edisto River Basin, South Carolina: Columbia, South Carolina Department of Natural Resources, $57 \mathrm{p}$.

Bulak, James, Crane, John, and Leitner, J., 1997, Fisheries investigations in lakes and streams, annual progress report F-63-3: South Carolina Department of Natural Resources, $97 \mathrm{p}$.

Clark, M.J.R., and Whitfield, P.H., 1994, Conflicting perspectives about detection limits and about the censoring of environmental data: Water Resources Bulletin, v. 1, no. 6, p. 1063-1079.

Cooney, T.W., Drewes, P.A., Jones, K.H., Gissendanner, J.W., and Church, B.W., 1998, Water resources data, South Carolina water year 1997: U.S. Geological Survey Water-Data Report SC-97-1, 498 p.

Crawford, J.K., and Luoma, S.N., 1994, Guidelines for studies of contaminants in biological tissues for the National Water-Quality Assessment Program: U.S. Geological Survey Open-File Report 92-494, 69 p.

Cuffney, T.F., Gurtz, M.E., and Meador, M.R., 1993, Methods for collecting benthic invertebrate samples as part of the National Water-Quality Assessment Program: U.S. Geological Survey Open-File Report 93-406, $66 \mathrm{p}$.

Ferrington, L.C., 1987, Collection and identification of floating exuviae of Chironomidae for use in studies of surface water quality: Kansas City, Kansas, U.S. Environmental Protection Agency Region VII, SOP No. 130A [variously paged].
Fishman, M.J., 1993, Methods of analysis by the U.S. Geological Survey National Water Quality Laboratory-Determination of inorganic and organic constituents in water and fluvial sediments: U.S. Geological Survey Open-File Report 93-125, 217 p.

Forstner, U., and Wittmann, G.T.W., 1979, Metal pollution in the aquatic environment: New York, Springer-Verlag, $486 \mathrm{p}$.

Helsel, D.R., and Hirsch, R.M., 1995, Statistical methods in water resources: New York, Elsevier, 529 p.

Hem, J.D., 1992, Study and interpretation of chemical characteristics of natural water: U.S. Geological Survey Water-Supply Paper 2254, 263 p.

Karr, J.R., 1981, Assessment of biotic integrity using fish communities: Fisheries, v. 6, p. 21-27.

Laws, E.A., 1993, Aquatic pollution: New York, John Wiley \& Sons, Inc., $611 \mathrm{p}$.

Lopes, T.J., Furlong, E.T., and Pritt, J.W., 1998, Occurrence and distribution of semivolatile organic compounds in streambed sediments, United States, 1992-95, in Little, E.E., DaLonay, A.J., and Greenberg, B.M., ed., Environmental toxicology and risk assessment, v. 7: Philadelphia, Pa., American Society for Testing and Materials, ASTM STP 1333, 416 pages.

Meador, M.R., Cuffney, T.F., and Gurtz, M.E., 1993, Methods for sampling fish communities as a part of the National Water-Quality Assessment Program: U.S. Geological Survey, Open-File Report 93-104, 40 p.

Meador, M.R., Hupp, C.L., Cuffney, T.F., and Gurtz, M.E., 1993, Methods for characterizing stream habitat as part of the National Water-Quality Assessment Program: U.S. Geological Survey Open-File Report 93-408, $48 \mathrm{p}$.

National Academy of Sciences and National Academy of Engineering, 1973, Water-quality criteria, 1972: Washington, D.C., National Academy of Sciences, $594 \mathrm{p}$.

National Park Service, 1996, Congaree Swamp National Monument freshwater fish species list: accessed March 2, 1999, at URL http://www.midnet.sc.edu/ cosw/coswfsh1.htm.

-1999, Congaree Swamp National Monument: accessed March 5, 1999, at URL http://www.midnet. sc.edu/cosw/coswres.htm.

National Safety Council, 1999, Di(2-ethylhexyl) Phthalate (C24H38O4): accessed June 28, 1999, at URL http://www.nsc.org/ehc/ew/chems/diphthal.htm.

Nowell, L.H., and Resek, E.A., 1994, Summary of national standards and guidelines for pesticides in water, bed sediment, and aquatic organisms and their applications to water-quality assessments: U.S. Geological Survey Open-File Report 94-44, 115 p. 
Patrick, Ruth, 1996, Rivers of the United States, Volume III, The eastern and southeastern states: New York, John Wiley \& Sons, Inc., 829 p.

Patterson, G.G., Speiran, G.K., and Whetstone, B.H., 1985, Hydrology and its effects on distribution of vegetation in Congaree Swamp National Monument, South Carolina: U.S. Geological Survey Water-Resources Investigations Report 85-4256, 31 p.

Patton, C.J., and Truitt, E.P., 1992, Methods of analysis by the U.S. Geological Survey National Water Quality Laboratory-Determination of total phosphorus by a Kjeldahl digestion method and an automated colorimetric finish that includes dialysis: U.S. Geological Survey Open-File Report 95-443, 35 p.

Plafkin, J.L., Barbour, M.T., Porter, K.D., Gross, S.K., and Hughes, R.M., 1989, Rapid bioassessment protocols for use in streams and rivers: U.S. Environmental Protection Agency, EPA/440/4-89/001 [variously paged].

Porter, S.D., Cuffney, T.F., Gurtz, M.E., and Meador, M.R., 1993, Methods for collecting algal samples as part of the National Water-Quality Assessment Program: U.S. Geological Survey Open-File Report 93-409, 39 p.

Rantz, S.E., and others, 1982, Measurement and computation of streamflow: Volume 1, Measurement of stage and discharge; Volume 2, Computation of discharge: U.S. Geological Survey Water-Supply Paper 2175 , v. 1,284 p.; v. 2, p. 285-631 [published separately].

Rodgers, J.H., Cherry, D.S., Dickson, K.L., and Cairns, J., Jr., 1979, Invasion, population dynamics and elemental accumulation of Corbicula fluminea in the New River at Glen Lyn, Va., in Proceedings of the First International Corbicula Symposium, Oct. 13-15, 1977: Fort Worth, Tex., p. 99-110.

Shelton, L.R., 1994, Field guide for collecting and processing stream-water samples for the National Water-Quality Assessment Program: U.S. Geological Survey Open-File Report 94-455, 42 p.

Shelton, L.R., and Capel, P.D., 1994, Guidelines for collecting and processing samples of stream-bed sediment for analysis of trace elements and organic contaminants for the National Water-Quality Assessment Program: U.S. Geological Survey OpenFile Report 94-458, 20 p.
South Carolina Department of Health and Environmental Control, 1993, Fish IBI for Twelve Mile Creek: South Carolina Department of Health and Environmental Control Technical Report No. 001-93 [variously paged].

-1995, Watershed water quality management strategy, Saluda-Edisto Basin: South Carolina Department of Health and Environmental Control Technical Report No. 003-95, 283 p.

South Carolina Department of Natural Resources, 1998, Climatological normals 1961-90: Southeast Regional Climate Center, accessed December 8, 1998, at URL http://water.dnr.state.sc.us/climate/sercc/products/ normals/381939_30yr_norm.html.

U.S. Environmental Protection Agency, 1986, Quality criteria for water, 1986: Washington D.C., U.S.

Environmental Protection Agency, EPA 570/9-82/002 [variously paged].

1996, Drinking water regulations and health advisories: U.S. Environmental Protection Agency, EPA 822B-96-002 [variously paged]. 1997, TSC 195 criteria chart: U.S. Environmental Protection Agency, Region IV, Water Management Division, $6 \mathrm{p}$. 1998, Di(2-ethylhexyl) phthalate (DEHP): Integrated Risk Information System, accessed March 11, 1999, at URL http://www.epa.gov/ngispgm3/iris/subst/ 0014.htm.

U.S. Geological Survey, 1999a, Glossary: accessed April 26, 1999, at URL http://wwwnwql.cr.usgs.gov/USGS/ Catalog/glossary.html. -1999b, National Water-Quality Assessment (NAWQA) Method and guideline protocols: accessed April 26, 1999, at URL http://wwwrvares.er.usgs.gov/ nawqa/protocols/doc_list.html.

Werner, S.L., Burkhardt, M.R., and DeRusseau, S.N., 1996, Methods of analysis by the U.S. Geological Survey National Water Quality Laboratory_-Determination of pesticides in water by Carbopak-B solid-phase extraction and high-performance liquid chromatography:

U.S. Geological Survey Open-File Report 96-216, 42 p.

Zaugg, S.D., Sandstrom, M.W., Smith, S.G., and Fehlberg, K.M., 1995, Methods of analysis by the U.S. Geological Survey National Water Quality Laboratory-Determination of pesticides in water by C-18 solid-phase extraction and capillary-column gas chromatography/mass spectrometry with selected-ion monitoring: U.S. Geological Survey Open-File Report 95-181, $49 \mathrm{p}$. 
APPENDIXES 
Appendix 1. Major ion concentrations in streams of Congaree Swamp

[mg/L, milligrams per liter; $\mu \mathrm{g} / \mathrm{L}$, micrograms per liter; —, no data]

CONGAREE RIVER AT COLUMBIA

\begin{tabular}{lcccccccccc}
\hline \multicolumn{1}{c}{ Date } & $\begin{array}{c}\text { Calcium } \\
(\mathbf{m g} / \mathbf{L})\end{array}$ & $\begin{array}{c}\text { Magnesium } \\
(\mathbf{m g} / \mathbf{L})\end{array}$ & $\begin{array}{c}\text { Sodium } \\
(\mathbf{m g} / \mathbf{L})\end{array}$ & $\begin{array}{c}\text { Potassium } \\
(\mathbf{m g} / \mathbf{L})\end{array}$ & $\begin{array}{c}\text { Sulfate } \\
(\mathbf{m g} / \mathbf{L})\end{array}$ & $\begin{array}{c}\text { Chloride } \\
(\mathbf{m g} / \mathbf{L})\end{array}$ & $\begin{array}{c}\text { Fluoride } \\
(\mathbf{m g} / \mathbf{L})\end{array}$ & $\begin{array}{c}\text { Silica } \\
(\mathbf{m g} / \mathbf{L})\end{array}$ & $\begin{array}{c}\text { Iron } \\
(\mu \mathbf{g} / \mathbf{L})\end{array}$ & $\begin{array}{c}\text { Manganese } \\
(\mu \mathbf{g} / \mathbf{L})\end{array}$ \\
\hline $10 / 23 / 95$ & 4.3 & 1.7 & 8.3 & 2.2 & 3.9 & 6.5 & 0.20 & 12 & 250 & 260 \\
$11 / 30 / 95$ & 4.0 & 1.7 & 7.6 & 2.4 & 5.1 & 6.2 & $<.10$ & 13 & 220 & 16 \\
$12 / 12 / 95$ & 4.4 & 1.8 & 9.3 & 2.2 & 5.0 & 7.2 & .20 & 14 & 200 & 9.0 \\
$1 / 10 / 96$ & 3.9 & 1.8 & 7.8 & 1.9 & 4.0 & 6.6 & .20 & 12 & 160 & 7.0 \\
$2 / 7 / 96$ & 3.0 & 1.5 & 5.6 & 2.0 & 4.5 & 4.8 & $<.10$ & 10 & 130 & 11 \\
$3 / 4 / 96$ & 3.9 & 1.7 & 7.7 & 1.9 & 4.2 & 6.5 & .10 & 12 & 180 & 9.0 \\
$3 / 8 / 96$ & 3.5 & 1.5 & 5.1 & 1.8 & 3.8 & 4.5 & $<.10$ & 9.7 & 74 & 10 \\
$4 / 23 / 96$ & 4.4 & 1.7 & 8.4 & 2.0 & 5.2 & 6.9 & $<.10$ & 12 & 300 & 11 \\
$5 / 15 / 96$ & 4.1 & 1.7 & 8.6 & 1.8 & 5.8 & 6.8 & $<.10$ & 12 & 170 & 8.0 \\
$6 / 5 / 96$ & 3.9 & 1.7 & 7.9 & 2.1 & 4.8 & 6.6 & $<.10$ & 12 & 120 & 9.0 \\
$7 / 3 / 96$ & 3.4 & 1.6 & 8.0 & 2.0 & 5.7 & 7.1 & .10 & 11 & 94 & 6.0 \\
$8 / 12 / 96$ & 3.5 & 1.7 & 10 & 1.9 & 6.7 & 7.9 & .10 & 10 & 120 & 8.0 \\
$9 / 4 / 96$ & 3.5 & 1.7 & 7.2 & 2.2 & 5.8 & 6.2 & $<.10$ & 10 & 70 & 64 \\
$10 / 21 / 96$ & 4.2 & 1.8 & 10 & 2.4 & 6.6 & 8.7 & .10 & 13 & 86 & 14 \\
$11 / 12 / 96$ & 4.0 & 1.7 & 9.5 & 2.4 & 6.7 & 7.6 & .10 & 12 & 110 & 5.0 \\
$12 / 5 / 96$ & 3.7 & 1.5 & 5.6 & 2.3 & 4.7 & 5.0 & $<.10$ & 11 & 77 & 15 \\
$1 / 31 / 97$ & 4.3 & 1.7 & 8.1 & 2.0 & 6.3 & 6.8 & .10 & 13 & 170 & 6.0 \\
$2 / 27 / 97$ & 3.7 & 1.7 & 8.0 & 2.2 & 6.0 & 6.4 & .11 & 11 & 39 & 8.0 \\
$3 / 2 / 97$ & 3.5 & 1.4 & 4.5 & 1.8 & 5.5 & 3.7 & $<.10$ & 9.6 & 320 & 9.0 \\
$3 / 10 / 97$ & 4.1 & 1.7 & 7.9 & 2.1 & 6.4 & 6.3 & $<.10$ & 12 & 130 & 9.0 \\
$4 / 7 / 97$ & 4.0 & 1.7 & 8.2 & 2.0 & 5.9 & 6.5 & .11 & 11 & 88 & 7.0 \\
$5 / 5 / 97$ & 3.9 & 1.7 & 6.6 & 1.9 & 5.5 & 5.5 & $<.10$ & 12 & 74 & 6.8 \\
$6 / 9 / 97$ & 3.6 & 1.6 & 7.7 & 1.9 & 5.3 & 6.2 & $<.10$ & 12 & 71 & 6.4 \\
$7 / 1 / 97$ & 3.9 & 1.7 & 8.6 & 2.1 & 5.5 & 7.1 & .11 & 10 & 62 & 9.6 \\
$8 / 6 / 97$ & 3.7 & 1.7 & 7.8 & 2.2 & 5.2 & 6.4 & .11 & 9.6 & 86 & 13 \\
$9 / 9 / 97$ & 3.8 & 1.8 & 11 & 2.3 & 7.4 & 8.4 & .11 & 8.4 & 82 & 19 \\
\hline
\end{tabular}

MYERS CREEK

\begin{tabular}{ccccccccccc}
\hline Date & $\begin{array}{c}\text { Calcium } \\
(\mathrm{mg} / \mathbf{L})\end{array}$ & $\begin{array}{c}\text { Magnesium } \\
(\mathrm{mg} / \mathbf{L})\end{array}$ & $\begin{array}{c}\text { Sodium } \\
(\mathrm{mg} / \mathbf{L})\end{array}$ & $\begin{array}{c}\text { Potassium } \\
(\mathrm{mg} / \mathbf{L})\end{array}$ & $\begin{array}{c}\text { Sulfate } \\
(\mathrm{mg} / \mathbf{L})\end{array}$ & $\begin{array}{c}\text { Chloride } \\
(\mathrm{mg} / \mathbf{L})\end{array}$ & $\begin{array}{c}\text { Fluoride } \\
(\mathrm{mg} / \mathbf{L})\end{array}$ & $\begin{array}{c}\text { Silica } \\
(\mathrm{mg} / \mathbf{L})\end{array}$ & $\begin{array}{c}\text { Iron } \\
(\mu \mathrm{g} / \mathbf{L})\end{array}$ & $\begin{array}{c}\text { Manganese } \\
(\mu \mathrm{g} / \mathbf{L})\end{array}$ \\
\hline $1 / 18 / 96$ & 0.92 & 0.61 & 3.2 & 0.80 & 1.1 & 4.9 & $<0.10$ & 7.3 & 450 & 28 \\
$3 / 27 / 96$ & 1.1 & .63 & 3.2 & .90 & 1.2 & 4.7 & $<.10$ & 4.6 & 550 & 50 \\
$6 / 24 / 96$ & .92 & .61 & 3.2 & 1.1 & 1.5 & 3.9 & $<.10$ & 10 & 180 & 33 \\
$9 / 12 / 96$ & 1.0 & .71 & 3.4 & 1.3 & 2.5 & 4.1 & $<.10$ & 10 & 310 & 71 \\
$12 / 16 / 96$ & .90 & .62 & 3.9 & 1.0 & 2.7 & 5.4 & $<.10$ & 11 & 440 & 42 \\
$3 / 17 / 97$ & 1.1 & .62 & 3.4 & 1.0 & 2.6 & 5.0 & $<.10$ & 6.2 & 590 & 82 \\
$6 / 30 / 97$ & 1.2 & .66 & 3.3 & .80 & 2.8 & 4.0 & $<.10$ & 11 & 750 & 110 \\
$9 / 29 / 97$ & 2.5 & 1.6 & 4.7 & 1.4 & 17 & 4.9 & $<.10$ & 14 & 350 & 374 \\
$12 / 10 / 97$ & .93 & .62 & 3.1 & 1.1 & 2.5 & 4.9 & $<.10$ & 8.4 & 360 & 62 \\
$3 / 5 / 98$ & 1.2 & .62 & 2.5 & 1.2 & 1.8 & 4.2 & $<.10$ & 2.0 & 480 & 39 \\
$6 / 8 / 98$ & 1.2 & .76 & 3.1 & 1.0 & 1.8 & 4.3 & $<.10$ & 9.7 & 710 & 52 \\
$9 / 1 / 98$ & .92 & .62 & 3.2 & 1.5 & 2.3 & 3.8 & $<.10$ & 9.4 & 400 & 41 \\
\hline
\end{tabular}


Appendix 1. Major ion concentrations in streams of Congaree Swamp-Continued [mg/L, milligrams per liter; $\mu \mathrm{g} / \mathrm{L}$, micrograms per liter; -, no data]

CEDAR CREEK

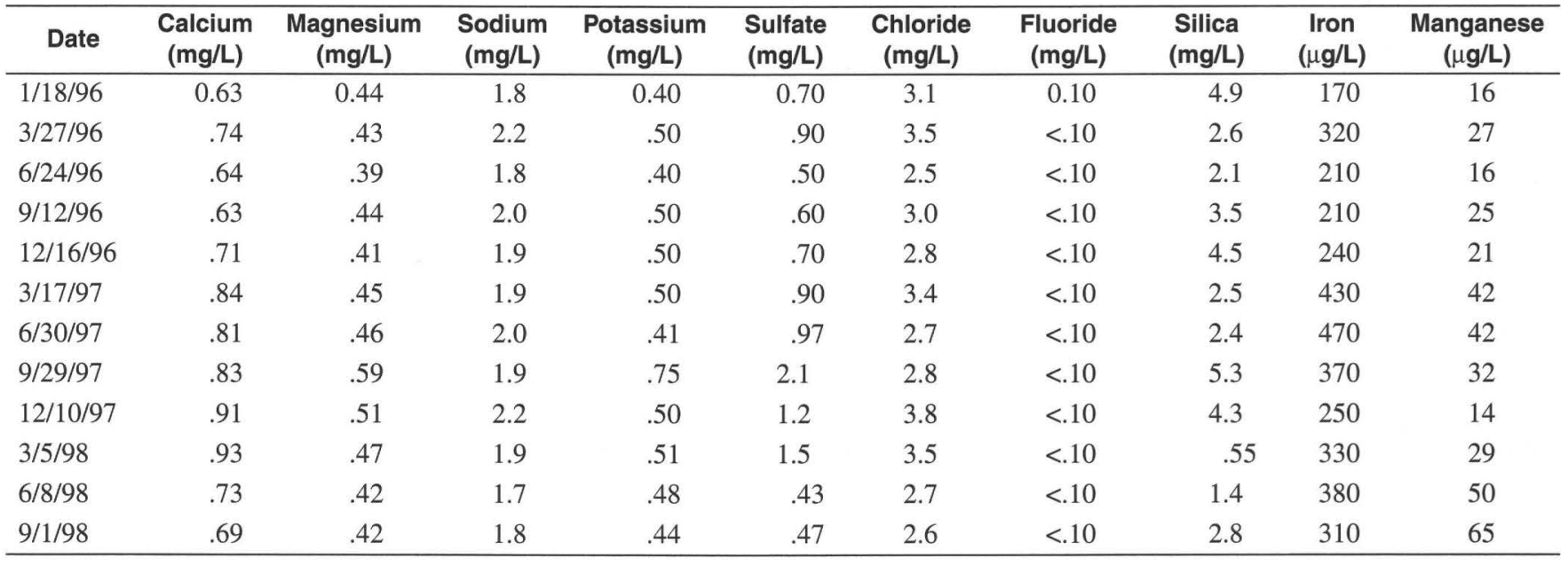

\section{CEDAR CREEK NEAR WISE LAKE}

\begin{tabular}{|c|c|c|c|c|c|c|c|c|c|c|}
\hline Date & $\begin{array}{l}\text { Calcium } \\
\text { (mg/L) }\end{array}$ & $\begin{array}{l}\text { Magnesium } \\
(\mathrm{mg} / \mathrm{L})\end{array}$ & $\begin{array}{l}\text { Sodium } \\
\text { (mg/L) }\end{array}$ & $\begin{array}{l}\text { Potassium } \\
\text { (mg/L) }\end{array}$ & $\begin{array}{l}\text { Sulfate } \\
\text { (mg/L) }\end{array}$ & $\begin{array}{c}\text { Chloride } \\
\text { (mg/L) }\end{array}$ & $\begin{array}{l}\text { Fluoride } \\
\text { (mg/L) }\end{array}$ & $\begin{array}{l}\text { Silica } \\
\text { (mg/L) }\end{array}$ & $\begin{array}{l}\text { Iron } \\
(\mu \mathrm{g} / \mathrm{L})\end{array}$ & $\begin{array}{l}\text { Manganese } \\
(\mu \mathrm{g} / \mathrm{L})\end{array}$ \\
\hline $1 / 18 / 96$ & 0.88 & 0.55 & 2.5 & 0.60 & 0.80 & 3.7 & $<0.10$ & 6.1 & 290 & 20 \\
\hline $3 / 26 / 96$ & 2.0 & .93 & 3.8 & 1.1 & 1.7 & 4.5 & $<.10$ & 5.3 & 580 & 37 \\
\hline $6 / 25 / 96$ & .72 & .47 & 2.0 & .50 & .50 & 2.9 & $<.10$ & 3.5 & 54 & 76 \\
\hline $9 / 12 / 96$ & .93 & .59 & 2.9 & .60 & 1.0 & 4.3 & $<.10$ & 4.7 & 88 & 95 \\
\hline $12 / 16 / 96$ & .79 & .53 & 2.4 & .60 & 1.3 & 3.4 & $<.10$ & 6.2 & 210 & 21 \\
\hline $6 / 30 / 97$ & 1.1 & .58 & 2.6 & .61 & 1.9 & 3.3 & $<.10$ & 6.4 & 650 & 78 \\
\hline $9 / 29 / 97$ & 1.7 & 1.0 & 3.1 & 1.0 & 7.8 & 3.7 & $<.10$ & 8.7 & 320 & 149 \\
\hline $12 / 11 / 97$ & 1.0 & .60 & 2.6 & .80 & 2.0 & 4.4 & $<.10$ & 6.8 & 410 & 36 \\
\hline $3 / 4 / 98$ & 1.9 & .88 & 2.8 & .94 & 2.0 & 3.6 & $<.10$ & 2.2 & 530 & 40 \\
\hline 6/9/98 & .94 & .49 & 2.3 & .60 & .76 & 3.1 & $<.10$ & 3.1 & 550 & 60 \\
\hline
\end{tabular}


Appendix 1. Major ion concentrations in streams of Congaree Swamp-Continued [mg/L, milligrams per liter; $\mu \mathrm{g} / \mathrm{L}$, micrograms per liter; -, no data]

\section{TOMS CREEK}

\begin{tabular}{lcccccccccc}
\hline Date & $\begin{array}{c}\text { Calcium } \\
(\mathbf{m g} / \mathbf{L})\end{array}$ & $\begin{array}{c}\text { Magnesium } \\
(\mathbf{m g} / \mathbf{L})\end{array}$ & $\begin{array}{c}\text { Sodium } \\
(\mathbf{m g} / \mathbf{L})\end{array}$ & $\begin{array}{c}\text { Potassium } \\
(\mathbf{m g} / \mathbf{L})\end{array}$ & $\begin{array}{c}\text { Sulfate } \\
(\mathrm{mg} / \mathbf{L})\end{array}$ & $\begin{array}{c}\text { Chloride } \\
(\mathrm{mg} / \mathbf{L})\end{array}$ & $\begin{array}{c}\text { Fluoride } \\
(\mathbf{m g} / \mathbf{L})\end{array}$ & $\begin{array}{c}\text { Silica } \\
(\mathrm{mg} / \mathbf{L})\end{array}$ & $\begin{array}{c}\text { Iron } \\
(\mu \mathbf{g} / \mathbf{L})\end{array}$ & $\begin{array}{c}\text { Manganese } \\
(\mu \mathrm{g} / \mathbf{L})\end{array}$ \\
\hline $3 / 26 / 96$ & 0.77 & 0.64 & 2.5 & 0.60 & 0.80 & 3.9 & $<0.10$ & 3.4 & 550 & 26 \\
$6 / 25 / 96$ & .82 & .83 & 2.5 & 3.3 & .60 & 3.7 & $<.10$ & 4.4 & 540 & 44 \\
$9 / 12 / 96$ & 1.1 & 1.0 & 2.7 & .90 & 4.8 & 3.7 & $<.10$ & 7.2 & 220 & 170 \\
$12 / 16 / 96$ & .75 & .76 & 2.8 & .60 & 1.6 & 4.4 & $<.10$ & 5.3 & 460 & 22 \\
$3 / 17 / 97$ & .92 & .71 & 2.6 & .80 & 1.7 & 4.7 & $<.10$ & 4.0 & 680 & 59 \\
$6 / 30 / 97$ & .88 & .79 & 2.3 & .52 & .95 & 3.4 & $<.10$ & 4.0 & 690 & 41 \\
$9 / 29 / 97$ & 1.3 & 1.2 & 3.0 & 1.1 & 6.1 & 4.5 & $<.10$ & 8.4 & 330 & 107 \\
$12 / 10 / 97$ & - & - & - & - & - & - & - & - & - & - \\
$3 / 4 / 98$ & .98 & .69 & 2.0 & .67 & 1.6 & 3.4 & .11 & .86 & 510 & 32 \\
$6 / 9 / 98$ & 1.1 & .94 & 2.5 & .59 & .90 & 3.8 & $<.10$ & 5.0 & 960 & 24 \\
$9 / 2 / 98$ & .93 & .93 & 2.7 & .81 & 1.1 & 3.8 & $<.10$ & 4.7 & 490 & 27 \\
\hline
\end{tabular}

${ }^{\text {a }}$ Site inaccessible. 
Appendix 2. Nutrient concentrations in streams of Congaree Swamp

[Concentrations in milligrams per liter; -, no data]

\section{CONGAREE RIVER AT COLUMBIA}

\begin{tabular}{|c|c|c|c|c|c|c|c|c|c|c|}
\hline Date & $\begin{array}{l}\text { Ammonia } \\
\text { nitrogen }\end{array}$ & $\begin{array}{c}\text { Total } \\
\text { ammonia- } \\
\text { plus- } \\
\text { organic } \\
\text { nitrogen }\end{array}$ & $\begin{array}{c}\text { Dissolved } \\
\text { ammonia- } \\
\text { plus- } \\
\text { organic } \\
\text { nitrogen }\end{array}$ & $\begin{array}{c}\text { Nitrite } \\
\text { nitrogen }\end{array}$ & $\begin{array}{c}\text { Nitrite- } \\
\text { plus- } \\
\text { nitrate } \\
\text { nitrogen }\end{array}$ & $\begin{array}{l}\text { Dissolved } \\
\text { phos- } \\
\text { phorus }\end{array}$ & $\begin{array}{l}\text { Total } \\
\text { phos- } \\
\text { phorus }\end{array}$ & $\begin{array}{l}\text { Ortho- } \\
\text { phos- } \\
\text { phorus }\end{array}$ & $\begin{array}{l}\text { Dis- } \\
\text { solved } \\
\text { organic } \\
\text { carbon }\end{array}$ & $\begin{array}{l}\text { Sus- } \\
\text { pended } \\
\text { organic } \\
\text { carbon }\end{array}$ \\
\hline $10 / 23 / 95$ & 0.040 & 0.20 & 0.20 & 0.010 & 0.290 & 0.020 & 0.303 & 0.020 & 2.3 & 0.40 \\
\hline $11 / 30 / 95$ & .020 & .20 & $<.20$ & $<.010$ & .290 & .020 & $<.010$ & .020 & 3.5 & .50 \\
\hline $12 / 12 / 95$ & $<.015$ & $<.20$ & $<.20$ & $<.010$ & .380 & .020 & .040 & .020 & 2.7 & .20 \\
\hline $1 / 10 / 96$ & $<.015$ & .20 & $<.20$ & $<.010$ & .330 & .020 & .050 & .020 & 3.2 & .30 \\
\hline $2 / 7 / 96$ & .020 & $<.20$ & $<.20$ & $<.010$ & .240 & $<.010$ & .030 & $<.010$ & 3.4 & .30 \\
\hline $3 / 4 / 96$ & $<.015$ & $<.20$ & $<.20$ & $<.010$ & .410 & .010 & .040 & .010 & 1.6 & .30 \\
\hline 3/8/96 & .040 & .50 & .40 & $<.010$ & .260 & .020 & .140 & .020 & 6.0 & 2.4 \\
\hline $4 / 23 / 96$ & $<.015$ & .20 & $<.20$ & $<.010$ & .320 & $<.010$ & .030 & $<.010$ & 2.0 & .30 \\
\hline $5 / 15 / 96$ & .120 & $<.20$ & $<.20$ & .010 & .310 & $<.010$ & .050 & $<.010$ & 2.8 & .30 \\
\hline $6 / 5 / 96$ & .020 & .30 & .20 & $<.010$ & .390 & .030 & .060 & .020 & 2.3 & .30 \\
\hline $7 / 3 / 96$ & .030 & $<.20$ & $<.20$ & .010 & .320 & .020 & .020 & .020 & 3.4 & .20 \\
\hline $8 / 12 / 96$ & .030 & $<.20$ & $<.20$ & .010 & .420 & $<.010$ & .020 & .020 & 2.5 & .30 \\
\hline $9 / 4 / 96$ & $<.015$ & .20 & $<.20$ & $<.010$ & .260 & $<.010$ & .020 & $<.010$ & 3.1 & .30 \\
\hline $10 / 21 / 96$ & $<.015$ & .40 & $<.20$ & .020 & .400 & .040 & .220 & .020 & 2.8 & .30 \\
\hline $11 / 12 / 96$ & .040 & .20 & $<.20$ & .020 & .320 & .030 & .050 & .020 & 3.5 & .30 \\
\hline $12 / 5 / 96$ & .050 & .40 & $<.20$ & $<.010$ & .350 & .020 & .100 & .030 & 3.8 & .90 \\
\hline $1 / 31 / 97$ & $<.015$ & .20 & $<.20$ & .010 & .400 & $<.010$ & .020 & $<.010$ & 3.1 & .30 \\
\hline $2 / 27 / 97$ & $<.015$ & .20 & $<.20$ & $<.010$ & .270 & $<.010$ & .030 & $<.010$ & 2.8 & .30 \\
\hline $3 / 2 / 97$ & .020 & 1.0 & .20 & $<.010$ & .270 & $<.010$ & .350 & .010 & 5.8 & 4.8 \\
\hline $3 / 10 / 97$ & $<.015$ & $<.20$ & $<.20$ & $<.010$ & .340 & $<.010$ & .020 & .010 & 3.2 & .20 \\
\hline $4 / 7 / 97$ & $<.015$ & $<.20$ & $<.20$ & $<.010$ & .330 & $<.010$ & .020 & .010 & 3.2 & - \\
\hline $5 / 5 / 97$ & $<.015$ & .30 & $<.20$ & $<.010$ & .422 & $<.010$ & .076 & .015 & 2.9 & .40 \\
\hline 6/9/97 & .019 & $<.20$ & $<.20$ & $<.010$ & .422 & $<.010$ & .016 & .020 & 2.3 & .30 \\
\hline $7 / 1 / 97$ & $<.015$ & .21 & $<.20$ & $<.010$ & .391 & $<.010$ & .016 & .017 & 3.3 & .10 \\
\hline $8 / 6 / 97$ & .017 & .62 & $<.20$ & $<.010$ & .270 & $<.010$ & .088 & .010 & 3.0 & .30 \\
\hline 9/9/97 & $<.015$ & .21 & $<.20$ & $<.010$ & .249 & $<.010$ & .012 & $<.010$ & 2.8 & .20 \\
\hline
\end{tabular}


Appendix 2. Nutrient concentrations in streams of Congaree Swamp-Continued [Concentrations in milligrams per liter; -, no data]

MYERS CREEK

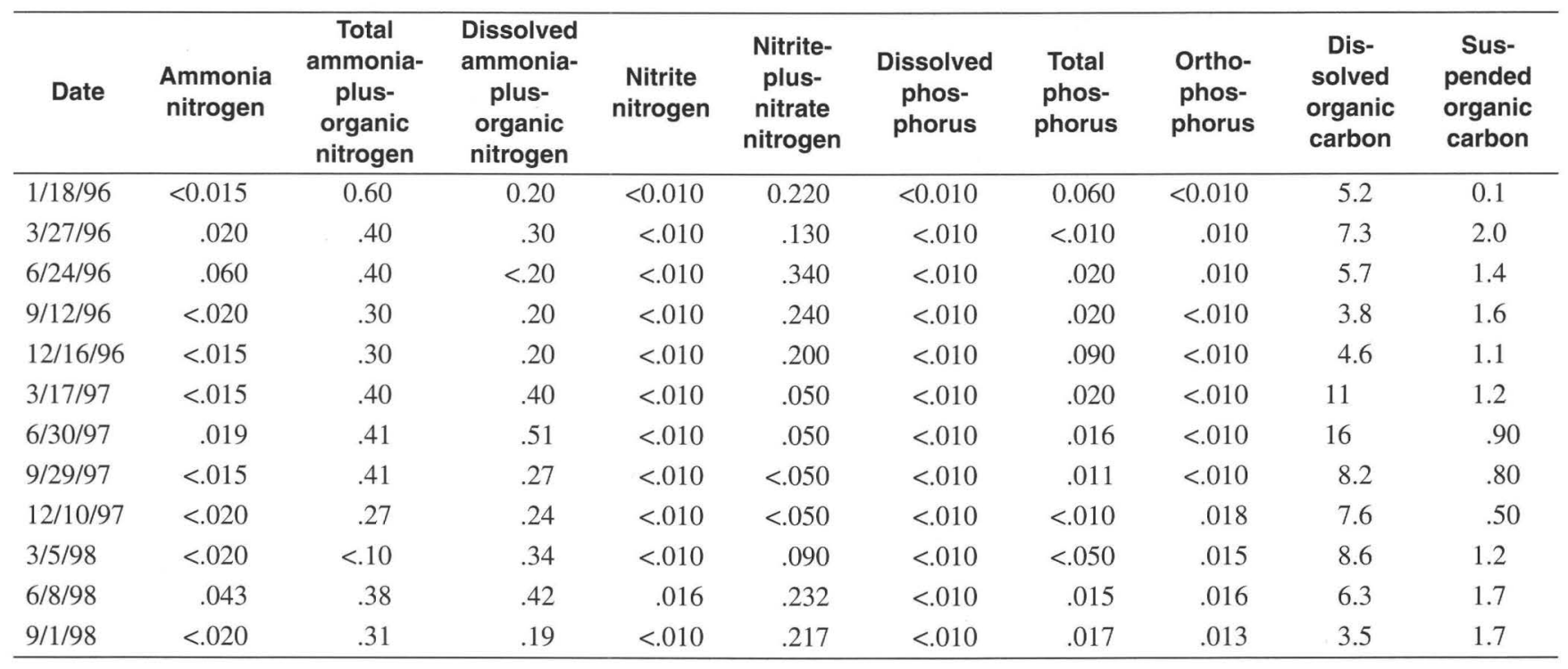

\section{CEDAR CREEK}

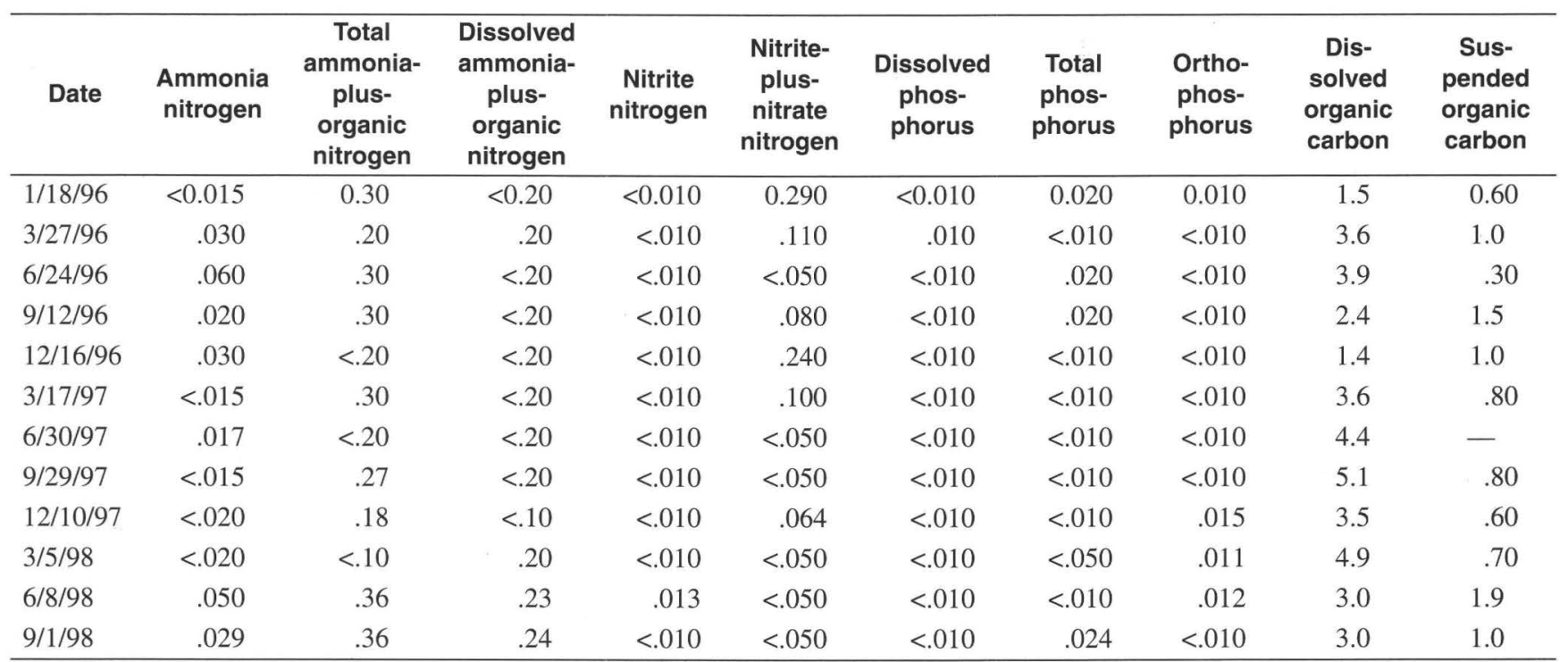


Appendix 2. Nutrient concentrations in streams of Congaree Swamp-Continued [Concentrations in milligrams per liter; - , no data]

\section{CEDAR CREEK NEAR WISE LAKE}

\begin{tabular}{|c|c|c|c|c|c|c|c|c|c|c|}
\hline Date & $\begin{array}{l}\text { Ammonia } \\
\text { nitrogen }\end{array}$ & $\begin{array}{c}\text { Total } \\
\text { ammonia- } \\
\text { plus- } \\
\text { organic } \\
\text { nitrogen }\end{array}$ & $\begin{array}{c}\text { Dissolved } \\
\text { ammonia- } \\
\text { plus- } \\
\text { organic } \\
\text { nitrogen }\end{array}$ & $\begin{array}{c}\text { Nitrite } \\
\text { nitrogen }\end{array}$ & $\begin{array}{c}\text { Nitrite- } \\
\text { plus- } \\
\text { nitrate } \\
\text { nitrogen }\end{array}$ & $\begin{array}{c}\text { Dissolved } \\
\text { phos- } \\
\text { phorus }\end{array}$ & $\begin{array}{c}\text { Total } \\
\text { phos- } \\
\text { phorus }\end{array}$ & $\begin{array}{l}\text { Ortho- } \\
\text { phos- } \\
\text { phorus }\end{array}$ & $\begin{array}{l}\text { Dis- } \\
\text { solved } \\
\text { organic } \\
\text { carbon }\end{array}$ & $\begin{array}{c}\text { Sus- } \\
\text { pended } \\
\text { organic } \\
\text { carbon }\end{array}$ \\
\hline $1 / 18 / 96$ & $<0.015$ & 0.20 & $<0.20$ & $<0.010$ & 0.250 & $<0.010$ & 0.020 & $<0.010$ & 2.5 & 0.80 \\
\hline $3 / 26 / 96$ & $<.015$ & .30 & .20 & $<.010$ & .100 & .020 & .020 & .010 & 5.0 & 1.3 \\
\hline $6 / 25 / 96$ & .070 & .20 & $<.20$ & $<.010$ & .110 & $<.010$ & $<.010$ & $<.010$ & 3.7 & .60 \\
\hline $9 / 12 / 96$ & .020 & .30 & .20 & $<.010$ & .090 & $<.010$ & .040 & $<.010$ & 3.9 & 1.5 \\
\hline $12 / 16 / 96$ & .020 & .20 & $<.20$ & $<.010$ & .200 & $<.010$ & $<.010$ & $<.010$ & 4.3 & .80 \\
\hline $3 / 17 / 97$ & $<.015$ & .40 & .40 & $<.010$ & .060 & $<.010$ & $<.010$ & $<.010$ & 7.7 & 1.1 \\
\hline $6 / 30 / 97$ & .026 & .32 & .27 & $<.010$ & $<.050$ & $<.010$ & .012 & $<.010$ & 8.4 & .90 \\
\hline $9 / 29 / 97$ & $<.015$ & .29 & .20 & $<.010$ & $<.050$ & $<.010$ & $<.010$ & $<.010$ & 5.9 & .70 \\
\hline $12 / 11 / 97$ & $<.020$ & .29 & .14 & $<.010$ & $<.050$ & $<.010$ & .012 & .012 & 5.4 & 1.2 \\
\hline 3/4/98 & $<.020$ & .37 & .29 & $<.010$ & $<.050$ & $<.010$ & .016 & $<.010$ & 6.9 & .60 \\
\hline 6/9/98 & .048 & .37 & .26 & .011 & .070 & $<.010$ & .080 & .012 & 3.6 & 2.4 \\
\hline $9 / 2 / 98$ & .040 & .35 & .21 & $<.010$ & $<.050$ & $<.010$ & .021 & .011 & 3.2 & 1.4 \\
\hline
\end{tabular}

\section{TOMS CREEK}

\begin{tabular}{|c|c|c|c|c|c|c|c|c|c|c|}
\hline Date & $\begin{array}{c}\text { Ammonia } \\
\text { nitrogen }\end{array}$ & $\begin{array}{c}\text { Total } \\
\text { ammonia- } \\
\text { plus- } \\
\text { organic } \\
\text { nitrogen }\end{array}$ & $\begin{array}{c}\text { Dissolved } \\
\text { ammonia- } \\
\text { plus- } \\
\text { organic } \\
\text { nitrogen }\end{array}$ & $\begin{array}{c}\text { Nitrite } \\
\text { nitrogen }\end{array}$ & $\begin{array}{c}\text { Nitrite- } \\
\text { plus- } \\
\text { nitrate } \\
\text { nitrogen }\end{array}$ & $\begin{array}{c}\text { Dissolved } \\
\text { phos- } \\
\text { phorus }\end{array}$ & $\begin{array}{c}\text { Total } \\
\text { phos- } \\
\text { phorus }\end{array}$ & $\begin{array}{l}\text { Ortho- } \\
\text { phos- } \\
\text { phorus }\end{array}$ & $\begin{array}{l}\text { Dis- } \\
\text { solved } \\
\text { organic } \\
\text { carbon }\end{array}$ & $\begin{array}{c}\text { Sus- } \\
\text { pended } \\
\text { organic } \\
\text { carbon }\end{array}$ \\
\hline $3 / 26 / 96$ & $<0.015$ & 0.30 & 0.20 & $<0.010$ & 0.210 & 0.010 & 0.010 & 0.010 & 5.3 & 1.1 \\
\hline $6 / 25 / 96$ & .060 & .40 & .20 & $<.010$ & .140 & $<.010$ & .020 & $<.010$ & 5.9 & .40 \\
\hline $9 / 12 / 96$ & .020 & .40 & .30 & $<.010$ & .110 & $<.010$ & .050 & .010 & 6.7 & 1.2 \\
\hline $3 / 17 / 97$ & $<.015$ & .40 & .40 & $<.010$ & $<.050$ & $<.010$ & $<.010$ & $<.010$ & 11 & 1.0 \\
\hline $6 / 30 / 97$ & .025 & .32 & .28 & $<.010$ & $<.050$ & $<.010$ & $<.010$ & $<.010$ & 8.3 & 1.1 \\
\hline $9 / 29 / 97$ & $<.015$ & .38 & .29 & $<.010$ & $<.050$ & $<.010$ & $<.010$ & $<.010$ & 9.6 & .80 \\
\hline $12 / 10 / 97^{\mathrm{a}}$ & - & - & - & - & - & - & - & - & - & - \\
\hline $3 / 4 / 98$ & $<.020$ & .33 & .31 & $<.010$ & $<.050$ & $<.010$ & $<.010$ & $<.010$ & 8.0 & .60 \\
\hline
\end{tabular}

${ }^{\text {a }}$ Site inaccessible. 
Appendix 3. Parameter codes and method detection limits for pesticides analyzed in samples from streams

of Congaree Swamp

[Units in micrograms per liter]

\begin{tabular}{|c|c|c|}
\hline Constituent & $\begin{array}{l}\text { Parameter } \\
\text { code }\end{array}$ & $\begin{array}{c}\text { Method } \\
\text { detection } \\
\text { limit }\end{array}$ \\
\hline 2,6-Diethylaniline & 82660 & 0.003 \\
\hline Acetochlor & 49260 & .002 \\
\hline Alachlor & 46342 & .002 \\
\hline Atrazine & 39632 & .001 \\
\hline Azinphos-methyl & 82686 & .001 \\
\hline Benfluralin & 82673 & .002 \\
\hline Butylate & 04028 & .002 \\
\hline Carbaryl & 82680 & .003 \\
\hline Carbofuran & 82674 & .003 \\
\hline Chlorpyrifos & 38933 & .004 \\
\hline Cyanazine & 04041 & .004 \\
\hline DCPA & 82682 & .002 \\
\hline Deethylatrazine & 04040 & .002 \\
\hline Diazinon & 39572 & .002 \\
\hline Dieldrin & 39381 & .001 \\
\hline Disulfoton & 82677 & .017 \\
\hline EPTC & 82668 & .002 \\
\hline Ethalfluralin & 82663 & .004 \\
\hline Ethoprophos & 82672 & .003 \\
\hline Fonofos & 04095 & .003 \\
\hline Lindane & 39341 & .004 \\
\hline Linuron & 82666 & .002 \\
\hline Malathion & 39532 & .005 \\
\hline Metolachlor & 39415 & .002 \\
\hline Metribuzin & 82630 & .004 \\
\hline Molinate & 82671 & .004 \\
\hline Napropamide & 82684 & .003 \\
\hline Parathion & 39542 & .004 \\
\hline Parathion-methyl & 82667 & .006 \\
\hline Pebulate & 82669 & .004 \\
\hline Pendimethalin & 82683 & .004 \\
\hline Phorate & 82664 & .002 \\
\hline Prometon & 04037 & .018 \\
\hline Propachlor & 04024 & .007 \\
\hline Propanil & 82679 & .004 \\
\hline Propargite & 82685 & .013 \\
\hline Pronamide & 82676 & .003 \\
\hline Simazine & 04035 & .005 \\
\hline Tebuthiuron & 82670 & .010 \\
\hline Terbacil & 82665 & .007 \\
\hline Terbufos & 82675 & .013 \\
\hline Thiobencarb & 82681 & .002 \\
\hline Tri-allate & 82678 & .001 \\
\hline Trifluralin & 82661 & .002 \\
\hline alpha-HCH & 34253 & .002 \\
\hline cis-Permethrin & 82687 & .005 \\
\hline$p, p^{\prime}-\mathrm{DDE}$ & 34653 & .006 \\
\hline
\end{tabular}


Appendix 4. Pesticide concentrations in streams of Congaree Swamp

[Concentrations in micrograms per liter; E, estimated value]

\section{CONGAREE RIVER AT COLUMBIA}

\begin{tabular}{|c|c|c|c|c|c|c|c|c|c|}
\hline Date & Deethylatrazine & Atrazine & DCPA & Diazinon & Metolachlor & Prometon & Pronamide & Simazine & Tebuthiuron \\
\hline $2 / 7 / 96$ & E0.0020 & 0.013 & E0.0010 & & E0.003 & E0.0040 & & 0.0530 & E0.0070 \\
\hline $5 / 15 / 96$ & E.0020 & .015 & & & .010 & E.0040 & & .0160 & E.0100 \\
\hline
\end{tabular}

\section{MYERS CREEK}

\begin{tabular}{|c|c|c|c|c|c|c|c|}
\hline Date & Deethylatrazine & Atrazine & Chlorpyrifos & Metolachlor & Prometon & Simazine & Tebuthiuron \\
\hline $3 / 27 / 96$ & E0.0040 & 0.058 & & 0.038 & E0.002 & 0.0110 & E0.0100 \\
\hline $6 / 24 / 96$ & & .005 & & .006 & & & .0140 \\
\hline $9 / 12 / 96$ & E.0023 & .005 & & .006 & & & .0195 \\
\hline $12 / 16 / 96$ & E.0010 & & & & & & E.0081 \\
\hline $3 / 17 / 97$ & & .005 & & .006 & & & E.0327 \\
\hline $9 / 29 / 97$ & & & E0.0037 & & & & \\
\hline $12 / 10 / 97$ & & & & & & & E.0128 \\
\hline $3 / 5 / 98$ & & E.003 & & .004 & & & .0114 \\
\hline 6/8/98 & & .011 & & .011 & & & .0200 \\
\hline 9/1/98 & & & & .006 & & & E.0090 \\
\hline
\end{tabular}

\section{CEDAR CREEK}

\begin{tabular}{|c|c|c|c|c|c|}
\hline Date & Alachlor & Deethylatrazine & Atrazine & Metolachlor & Tebuthiuron \\
\hline $3 / 27 / 96$ & & E0.003 & 0.009 & 0.005 & 0.0130 \\
\hline $6 / 24 / 96$ & $\mathrm{E} 0.002$ & & .005 & E.004 & .0110 \\
\hline $9 / 12 / 96$ & & & E.004 & & .0250 \\
\hline $12 / 16 / 96$ & & & & & .0193 \\
\hline $3 / 17 / 97$ & & & .009 & .005 & E.0392 \\
\hline \multicolumn{6}{|l|}{$9 / 29 / 97$} \\
\hline $12 / 10 / 97$ & & & & & E.0205 \\
\hline $3 / 5 / 98$ & & & & & .0150 \\
\hline $6 / 8 / 98$ & & & .008 & & .0200 \\
\hline 9/1/98 & & & & & .0140 \\
\hline
\end{tabular}


Appendix 4. Pesticide concentrations in streams of Congaree Swamp-Continued

[Concentrations in micrograms per liter; $E$, estimated value]

CEDAR CREEK NEAR WISE LAKE

\begin{tabular}{|c|c|c|c|c|c|c|}
\hline Date & Deethylatrazine & Atrazine & Metolachlor & Prometon & Simazine & Tebuthiuron \\
\hline $3 / 26 / 96$ & E0.0040 & 0.030 & 0.019 & E0.0020 & 0.0100 & E0.0100 \\
\hline $6 / 25 / 96$ & E.0010 & .004 & .004 & & & .0230 \\
\hline 9/12/96 & E.0014 & .004 & & & & .0173 \\
\hline $12 / 16 / 96$ & & & & & & .0200 \\
\hline $3 / 17 / 97$ & & .008 & .005 & & & .0194 \\
\hline \multicolumn{7}{|l|}{ 9/29/97 } \\
\hline $12 / 11 / 97$ & & & & & & E.0198 \\
\hline $3 / 4 / 98$ & & E.004 & E.003 & & & .0124 \\
\hline 6/9/98 & & .005 & E. 003 & & & .0165 \\
\hline 9/2/98 & & & & & & \\
\hline
\end{tabular}

TOMS CREEK

\begin{tabular}{|c|c|c|c|c|c|}
\hline Date & Deethylatrazine & Atrazine & Carbaryl & Metolachlor & Tebuthiuron \\
\hline $3 / 26 / 96$ & E0.0030 & 0.004 & & E0.003 & 0.0240 \\
\hline $6 / 25 / 96$ & E.0020 & .005 & & .007 & .0680 \\
\hline 9/12/96 & E.0023 & .005 & E0.0064 & E.004 & .0844 \\
\hline $12 / 16 / 96$ & E.0021 & & & & .0495 \\
\hline $3 / 17 / 97$ & E.0018 & E.004 & & .004 & E.0166 \\
\hline 9/29/97 & & & & & .0124 \\
\hline \multicolumn{6}{|l|}{$12 / 10 / 97^{\mathrm{a}}$} \\
\hline $3 / 4 / 98$ & & & & & .0189 \\
\hline 6/9/98 & E. 0043 & .007 & & E.002 & .0385 \\
\hline 9/2/98 & & & & & .0462 \\
\hline
\end{tabular}

${ }^{\text {a }}$ Site inaccessible. 
Appendix 5. Suspended sediment in streams of Congaree Swamp [mg/L, milligrams per liter; mm, millimeters; —, no data]

CONGAREE RIVER AT COLUMBIA

\begin{tabular}{|c|c|c|}
\hline Date & $\begin{array}{c}\text { Suspended } \\
\text { sediment } \\
\text { (mg/L) }\end{array}$ & $\begin{array}{l}\text { Percent finer } \\
\text { than } 0.062 \mathrm{~mm}\end{array}$ \\
\hline $10 / 23 / 95$ & 7 & 88 \\
\hline $11 / 30 / 95$ & 12 & 90 \\
\hline $12 / 12 / 95$ & 13 & 80 \\
\hline $1 / 10 / 96$ & 5 & 74 \\
\hline $2 / 7 / 96$ & 35 & 76 \\
\hline $3 / 4 / 96$ & 5 & 81 \\
\hline $3 / 8 / 96$ & 136 & 77 \\
\hline $4 / 23 / 96$ & 22 & 36 \\
\hline $5 / 15 / 96$ & 6 & 93 \\
\hline $6 / 5 / 96$ & 10 & 89 \\
\hline $7 / 3 / 96$ & 8 & 96 \\
\hline $8 / 12 / 96$ & 62 & 14 \\
\hline $9 / 4 / 96$ & 13 & 63 \\
\hline $10 / 21 / 96$ & 6 & 74 \\
\hline $11 / 12 / 96$ & 12 & 92 \\
\hline $12 / 5 / 96$ & 248 & 24 \\
\hline $1 / 31 / 97$ & 15 & 91 \\
\hline $2 / 27 / 97$ & 36 & 22 \\
\hline $3 / 2 / 97$ & 248 & 90 \\
\hline $3 / 10 / 97$ & 14 & 62 \\
\hline $4 / 7 / 97$ & 6 & 93 \\
\hline $5 / 5 / 97$ & 47 & 89 \\
\hline $6 / 9 / 97$ & 16 & 77 \\
\hline $7 / 1 / 97$ & 6 & 72 \\
\hline $8 / 6 / 97$ & 7 & 81 \\
\hline 9/9/97 & 3 & 62 \\
\hline
\end{tabular}

MYERS CREEK

\begin{tabular}{lcc}
\hline Date & $\begin{array}{c}\text { Suspended } \\
\text { sediment } \\
\text { (mg/L) }\end{array}$ & $\begin{array}{c}\text { Percent finer } \\
\text { than } \mathbf{0 . 0 6 2} \mathbf{~ m m}\end{array}$ \\
\hline $3 / 27 / 96$ & 12 & 84 \\
$6 / 24 / 96$ & 9 & 86 \\
$9 / 12 / 96$ & 7 & 54 \\
$12 / 16 / 96$ & 2 & 80 \\
$3 / 17 / 97$ & 4 & 90 \\
$6 / 30 / 97$ & 8 & 60 \\
$9 / 29 / 97$ & 5 & 30 \\
$12 / 10 / 97$ & 11 & 36 \\
$3 / 5 / 98$ & 13 & 85 \\
$6 / 8 / 98$ & 7 & 69 \\
$9 / 1 / 98$ & 6 & 82 \\
\hline
\end{tabular}

\section{CEDAR CREEK}

\begin{tabular}{lcc}
\hline Date & $\begin{array}{c}\text { Suspended } \\
\text { sediment } \\
\text { (mg/L) }\end{array}$ & $\begin{array}{c}\text { Percent finer } \\
\text { than 0.062 mm }\end{array}$ \\
\hline $1 / 18 / 96$ & 2 & 71 \\
$3 / 27 / 96$ & 9 & 74 \\
$6 / 24 / 96$ & 7 & 70 \\
$9 / 12 / 96$ & 5 & 52 \\
$12 / 16 / 96$ & 4 & 86 \\
$3 / 17 / 97$ & 3 & 90 \\
$6 / 30 / 97$ & 6 & 71 \\
$9 / 29 / 97$ & 3 & 25 \\
$12 / 10 / 97$ & 2 & 20 \\
$3 / 5 / 98$ & 6 & 76 \\
$6 / 8 / 98$ & 4 & 72 \\
9/1/98 & 7 & 64 \\
\hline
\end{tabular}


Appendix 5. Suspended sediment in streams of Congaree Swamp-Continued [mg/L, milligrams per liter; mm, millimeters; -, no data]

\section{CEDAR CREEK NEAR WISE LAKE}

\begin{tabular}{lcc}
\hline Date & $\begin{array}{c}\text { Suspended } \\
\text { sediment } \\
\text { (mg/L) }\end{array}$ & $\begin{array}{c}\text { Percent finer } \\
\text { than 0.062 } \mathbf{~ m m}\end{array}$ \\
\hline $1 / 18 / 96$ & 3 & 78 \\
$3 / 26 / 96$ & 10 & 82 \\
$6 / 25 / 96$ & 7 & 86 \\
$9 / 12 / 96$ & 7 & 74 \\
$12 / 16 / 96$ & 3 & 88 \\
$3 / 17 / 97$ & 7 & 90 \\
$6 / 30 / 97$ & 9 & 76 \\
$9 / 29 / 97$ & 7 & 38 \\
$12 / 11 / 97$ & 3 & 73 \\
$3 / 4 / 98$ & 7 & 95 \\
$6 / 9 / 98$ & 7 & 59 \\
$9 / 2 / 98$ & 7 & 79 \\
\hline
\end{tabular}

\section{TOMS CREEK}

\begin{tabular}{lcc}
\hline Date & $\begin{array}{c}\text { Suspended } \\
\text { sediment } \\
\text { (mg/L) }\end{array}$ & $\begin{array}{c}\text { Percent finer } \\
\text { than } \mathbf{0 . 0 6 2} \mathbf{~ m m}\end{array}$ \\
\hline $3 / 26 / 96$ & 11 & 59 \\
$6 / 25 / 96$ & 5 & 79 \\
$9 / 12 / 96$ & 6 & 74 \\
$12 / 16 / 96$ & 2 & 72 \\
$3 / 17 / 97$ & 1 & 40 \\
$6 / 30 / 97$ & 11 & 79 \\
$9 / 29 / 97$ & 4 & 50 \\
$12 / 10 / 97^{\text {a }}$ & - & - \\
$3 / 4 / 98$ & 7 & 78 \\
$6 / 9 / 98$ & 21 & 24 \\
$9 / 2 / 98$ & 5 & 59 \\
\hline
\end{tabular}

${ }^{\mathrm{a}}$ Site inaccessible. 
Appendix 6. Field-measured constituents in streams of Congaree Swamp

$\left[\mathrm{ft}^{3} / \mathrm{s}\right.$, cubic feet per second; $\mu \mathrm{S} / \mathrm{cm}$, microsiemens per centimeter; ${ }^{\circ} \mathrm{C}$, degrees Celsius; su, standard units; $\mathrm{mg} / \mathrm{L}$, milligrams per liter; \%, percent; -, no data]

CONGAREE RIVER AT COLUMBIA

\begin{tabular}{|c|c|c|c|c|c|c|c|}
\hline Date & $\begin{array}{c}\text { Streamflow } \\
\left(\mathrm{ft}^{3} / \mathrm{s}\right)\end{array}$ & $\begin{array}{c}\text { Specific } \\
\text { conductance } \\
(\mu \mathrm{S} / \mathrm{cm})\end{array}$ & $\begin{array}{c}\text { Temperature } \\
\left({ }^{\circ} \mathrm{C}\right)\end{array}$ & $\begin{array}{l}\mathrm{pH} \\
\text { (su) }\end{array}$ & $\begin{array}{c}\text { Dissolved } \\
\text { oxygen } \\
(\mathrm{mg} / \mathrm{L})\end{array}$ & $\begin{array}{c}\text { Dissolved } \\
\text { oxygen } \\
\text { saturation } \\
(\%)\end{array}$ & $\begin{array}{c}\text { Alkalinity } \\
\text { (mg/L) }\end{array}$ \\
\hline $10 / 23 / 95$ & 6,330 & 85 & 18.5 & 7.3 & 8.4 & 90 & 21 \\
\hline $11 / 30 / 95$ & 16,200 & 73 & 13.0 & 7.0 & 8.4 & 81 & 20 \\
\hline $12 / 12 / 95$ & 10,500 & 84 & 10.0 & 7.2 & 10.0 & 82 & 24 \\
\hline $1 / 10 / 96$ & 9,430 & 80 & 6.0 & 7.2 & 10.0 & 79 & 21 \\
\hline 2/7/96 & 14,800 & 60 & 6.0 & 7.1 & 12.5 & 97 & 15 \\
\hline $3 / 4 / 96$ & 8,260 & 81 & 11.0 & 7.4 & 6.9 & 62 & 18 \\
\hline $3 / 8 / 96$ & 53,600 & 39 & 11.5 & 7.1 & 9.7 & 88 & 14 \\
\hline 4/23/96 & 7,820 & 84 & 19.0 & 7.7 & 6.4 & 69 & 21 \\
\hline $5 / 15 / 96$ & 6,420 & 79 & 17.0 & 7.2 & 7.2 & 77 & 22 \\
\hline $6 / 5 / 96$ & 6,640 & 79 & 20.2 & 6.9 & 7.2 & 82 & 20 \\
\hline 7/3/96 & 6,030 & 101 & 25.0 & 5.5 & 7.6 & 89 & 18 \\
\hline $8 / 12 / 96$ & 4,710 & 86 & 26.0 & 7.2 & 6.9 & 85 & 20 \\
\hline 9/4/96 & 17,100 & 69 & 16.5 & 6.6 & 5.8 & 59 & 17 \\
\hline $10 / 21 / 96$ & 2,460 & 92 & 17.5 & 7.2 & 9.1 & 91 & 22 \\
\hline $11 / 12 / 96$ & 7,760 & 92 & 13.0 & 7.0 & 9.2 & 88 & 22 \\
\hline $12 / 5 / 96$ & 7,820 & 64 & 9.5 & 6.8 & 10.3 & 90 & 13 \\
\hline $1 / 31 / 97$ & 12,200 & 83 & 9.0 & 7.2 & 10.4 & 90 & 36 \\
\hline $2 / 27 / 97$ & 16,900 & 78 & 10.5 & 7.1 & 10.7 & 95 & 18 \\
\hline $3 / 2 / 97$ & 40,400 & 51 & 14.0 & 6.3 & 8.3 & 80 & 19 \\
\hline 3/10/97 & 9,190 & 80 & 12.5 & 7.1 & 10.0 & 97 & 19 \\
\hline $4 / 7 / 97$ & 8,920 & 80 & 15.5 & 7.1 & 9.5 & 95 & 26 \\
\hline $5 / 5 / 97$ & 15,200 & 73 & 17.0 & 6.4 & 8.7 & 90 & 18 \\
\hline 6/9/97 & 5,710 & 75 & 19.0 & 6.8 & 6.2 & 65 & 22 \\
\hline 7/1/97 & 8,920 & 85 & 22.0 & 7.0 & 8.2 & 90 & 21 \\
\hline $8 / 6 / 97$ & 6,390 & 81 & 22.5 & 7.0 & 7.2 & 87 & 20 \\
\hline 9/9/97 & 2,940 & 100 & 22.5 & 6.4 & 7.2 & 83 & 22 \\
\hline
\end{tabular}


Appendix 6. Field-measured constituents in streams of Congaree Swamp-Continued $\left[\mathrm{ft}^{3} / \mathrm{s}\right.$, cubic feet per second; $\mu \mathrm{S} / \mathrm{cm}$, microsiemens per centimeter; ${ }^{\circ} \mathrm{C}$, degrees Celsius; su, standard units; $\mathrm{mg} / \mathrm{L}$, milligrams per liter; \%, percent; - , no data]

\section{MYERS CREEK}

\begin{tabular}{|c|c|c|c|c|c|c|c|}
\hline Date & $\begin{array}{l}\text { Streamflow } \\
\left(\mathrm{ft}^{3} / \mathrm{s}\right)\end{array}$ & $\begin{array}{c}\text { Specific } \\
\text { conductance } \\
(\mu \mathrm{S} / \mathrm{cm})\end{array}$ & $\begin{array}{c}\text { Temperature } \\
\left({ }^{\circ} \mathrm{C}\right)\end{array}$ & $\begin{array}{l}\mathrm{pH} \\
\text { (su) }\end{array}$ & $\begin{array}{l}\text { Dissolved } \\
\text { oxygen } \\
\text { (mg/L) }\end{array}$ & $\begin{array}{l}\text { Dissolved } \\
\text { oxygen } \\
\text { saturation } \\
(\%)\end{array}$ & $\begin{array}{c}\text { Alkalinity } \\
(\mathrm{mg} / \mathrm{L})\end{array}$ \\
\hline $1 / 18 / 96$ & 19 & 28 & 9.5 & 4.7 & 9.9 & 91 & 3 \\
\hline $3 / 27 / 96$ & 26 & 29 & 14.0 & 5.6 & 8.6 & 83 & 7 \\
\hline $6 / 24 / 96$ & 3.9 & 28 & 24.0 & 5.7 & 5.8 & 71 & 4 \\
\hline $9 / 12 / 96$ & 2.5 & 32 & 22.0 & 5.9 & 7.4 & 86 & 5 \\
\hline $12 / 16 / 96$ & 7.2 & 28 & 6.0 & 5.3 & 10.7 & 86 & 3 \\
\hline $3 / 17 / 97$ & 3.0 & 32 & 9.0 & 5.2 & 9.1 & 78 & 4 \\
\hline $6 / 30 / 97$ & 30 & 33 & 21.5 & 5.1 & 6.0 & 68 & 1 \\
\hline 9/29/97 & 38 & 68 & 19.5 & 4.4 & 5.0 & 54 & 2 \\
\hline $12 / 10 / 97$ & 32 & 28 & 7.0 & 5.1 & 8.8 & 77 & 2 \\
\hline $3 / 5 / 98$ & 52 & 25 & 9.0 & 5.4 & 8.8 & 76 & 2 \\
\hline 6/8/98 & 9.7 & 28 & 17.5 & 5.7 & 7.1 & 74 & 5 \\
\hline 9/1/98 & 1.4 & 28 & 23.0 & 5.5 & 6.3 & 76 & 4 \\
\hline
\end{tabular}

\section{CEDAR CREEK}

\begin{tabular}{|c|c|c|c|c|c|c|c|}
\hline Date & $\begin{array}{l}\text { Streamflow } \\
\left(\mathrm{ft}^{3} / \mathrm{s}\right)\end{array}$ & $\begin{array}{c}\text { Specific } \\
\text { conductance } \\
(\mu \mathrm{S} / \mathrm{cm})\end{array}$ & $\begin{array}{c}\text { Temperature } \\
\left({ }^{\circ} \mathrm{C}\right)\end{array}$ & $\begin{array}{l}\mathrm{pH} \\
\text { (su) }\end{array}$ & $\begin{array}{l}\text { Dissolved } \\
\text { oxygen } \\
\text { (mg/L) }\end{array}$ & $\begin{array}{l}\text { Dissolved } \\
\text { oxygen } \\
\text { saturation } \\
(\%)\end{array}$ & $\begin{array}{c}\text { Alkalinity } \\
\text { (mg/L) }\end{array}$ \\
\hline $1 / 18 / 96$ & 38 & 17 & 9.5 & 5.4 & 10.6 & 93 & 2 \\
\hline $3 / 27 / 96$ & 39 & 20 & 15.5 & 5.8 & 9.2 & 93 & 2 \\
\hline $6 / 24 / 96$ & 27 & 15 & 29.5 & 5.0 & 6.3 & 82 & 4 \\
\hline $9 / 12 / 96$ & 22 & 18 & 26.5 & 5.9 & 6.6 & 83 & 3 \\
\hline $12 / 16 / 96$ & 30 & 14 & 7.0 & 5.7 & 11.4 & 94 & 3 \\
\hline $3 / 17 / 97$ & 40 & 20 & 15.5 & 5.7 & 9.3 & 94 & 3 \\
\hline $6 / 30 / 97$ & 36 & 19 & 26.5 & 5.9 & 7.2 & 90 & 2 \\
\hline 9/29/97 & 56 & 20 & 20.5 & 5.1 & 7.4 & 82 & 3 \\
\hline $12 / 10 / 97$ & 43 & 19 & 7.5 & 5.4 & 10.5 & 87 & 2 \\
\hline $3 / 5 / 98$ & 61 & 18 & 11.5 & 5.5 & 10.1 & 93 & 3 \\
\hline 6/8/98 & 37 & 16 & 24.5 & 5.6 & 7.1 & 86 & 3 \\
\hline 9/1/98 & 24 & 16 & 28.0 & 5.6 & 6.6 & 84 & 4 \\
\hline
\end{tabular}


Appendix 6. Field-measured constituents in streams of Congaree Swamp-Continued $\left[\mathrm{ft}^{3} / \mathrm{s}\right.$, cubic feet per second; $\mu \mathrm{S} / \mathrm{cm}$, microsiemens per centimeter; ${ }^{\circ} \mathrm{C}$, degrees Celsius; su, standard units; $\mathrm{mg} / \mathrm{L}$, milligrams per liter; \%, percent; -, no data]

CEDAR CREEK NEAR WISE LAKE

\begin{tabular}{|c|c|c|c|c|c|c|c|}
\hline Date & $\begin{array}{c}\text { Streamflow } \\
\left(\mathrm{ft}^{3} / \mathrm{s}\right)\end{array}$ & $\begin{array}{c}\text { Specific } \\
\text { conductance } \\
(\mu \mathrm{S} / \mathrm{cm})\end{array}$ & $\begin{array}{c}\text { Temperature } \\
\left({ }^{\circ} \mathrm{C}\right)\end{array}$ & $\begin{array}{l}\mathrm{pH} \\
\text { (su) }\end{array}$ & $\begin{array}{c}\text { Dissolved } \\
\text { oxygen } \\
\text { (mg/L) }\end{array}$ & $\begin{array}{c}\text { Dissolved } \\
\text { oxygen } \\
\text { saturation } \\
(\%)\end{array}$ & $\begin{array}{c}\text { Alkalinity } \\
\text { (mg/L) }\end{array}$ \\
\hline $1 / 18 / 96$ & 48 & 20 & 10.0 & 5.6 & 10.3 & 92 & 2 \\
\hline $3 / 26 / 96$ & 86 & 39 & 14.0 & 6.1 & 7.6 & 74 & 13 \\
\hline $6 / 25 / 96$ & 24 & 20 & 28.0 & 5.6 & 4.7 & 61 & 4 \\
\hline 9/12/96 & 16 & 24 & 25.0 & 5.8 & 4.2 & 51 & 3 \\
\hline $12 / 16 / 96$ & 34 & 22 & 7.5 & 5.9 & 10.0 & 83 & 3 \\
\hline 3/17/97 & 72 & 31 & 13.0 & 5.7 & 8.4 & 79 & 6 \\
\hline 6/30/97 & 56 & 25 & 24.5 & 5.5 & 6.4 & 77 & 2 \\
\hline 9/29/97 & 95 & 32 & 20.0 & 5.0 & 6.4 & 71 & 1 \\
\hline $12 / 11 / 97$ & 89 & 24 & 7.5 & 5.6 & 9.7 & 81 & 2 \\
\hline $3 / 4 / 98$ & 160 & 27 & 9.5 & 6.4 & 8.4 & 74 & 6 \\
\hline 6/9/98 & 44 & 11 & 23.0 & 6.1 & 6.0 & 70 & 3 \\
\hline $9 / 2 / 98$ & 27 & 18 & 26.5 & 5.7 & 5.9 & 73 & 3 \\
\hline
\end{tabular}

TOMS CREEK

\begin{tabular}{lccccccc}
\hline \multicolumn{1}{c}{ Date } & $\begin{array}{c}\text { Streamflow } \\
\left(\mathbf{f t}^{\mathbf{3}} / \mathbf{s}\right)\end{array}$ & $\begin{array}{c}\text { Specific } \\
\text { conductance } \\
(\mu \mathbf{S} / \mathbf{c m})\end{array}$ & $\begin{array}{c}\text { Temperature } \\
\left({ }^{\circ} \mathbf{C}\right)\end{array}$ & $\begin{array}{c}\mathbf{p H} \\
(\mathbf{s u})\end{array}$ & $\begin{array}{c}\text { Dissolved } \\
\text { oxygen } \\
(\mathbf{m g} / \mathbf{L})\end{array}$ & $\begin{array}{c}\text { Dissolved } \\
\text { oxygen } \\
\text { saturation } \\
(\%)\end{array}$ & $\begin{array}{c}\text { Alkalinity } \\
(\mathbf{m g} / \mathbf{L})\end{array}$ \\
\hline $3 / 26 / 96$ & 33 & 24 & 16.5 & 5.6 & 8.6 & 87 & 4 \\
$6 / 25 / 96$ & 8.9 & 25 & 26.5 & 6.3 & 5.3 & 71 & 4 \\
$9 / 12 / 96$ & 8.5 & 32 & 24.0 & 5.5 & 5.1 & 60 & 2 \\
$12 / 16 / 96$ & 11 & 26 & 8.0 & 6.1 & 10.2 & 85 & 3 \\
$3 / 17 / 97$ & 48 & 27 & 11.5 & 5.4 & 9.6 & 89 & 3 \\
$6 / 30 / 97$ & 29 & 23 & 25.0 & 5.6 & 6.2 & 72 & 3 \\
$9 / 29 / 97$ & 53 & 39 & 20.0 & 4.9 & 5.7 & 63 & 2 \\
$12 / 10 / 97^{\text {a }}$ & - & - & - & - & - & - & - \\
$3 / 4 / 98$ & 103 & 18 & 9.0 & 5.4 & 9.5 & 83 & 4 \\
$6 / 9 / 98$ & 23 & 24 & 20.5 & 5.3 & 6.7 & 74 & 4 \\
$9 / 2 / 98$ & 5.9 & 27 & 25.0 & 6.1 & 6.8 & 80 & 4 \\
\hline
\end{tabular}

${ }^{\text {a}}$ Site inaccessible. 


\section{MYERS CREEK}

[T-n, transect number; m, meters; >, greater than; OD, organic detritus; MU, muck; SA, sand; SI, silt; I, island; Y, yes; NO, none; NA, not applicable. Referring to bank shape: LN, linear; CC, concave; CV, convex. Referring to bank erosion: CB, undercut bank; SL, slab failure; RO rotational failure]

\begin{tabular}{|c|c|c|c|c|c|c|}
\hline Habitat characteristic & $\mathrm{T}-1$ & $\mathrm{~T}-2$ & T-3 & T-4 & $\mathrm{T}-5$ & T-6 \\
\hline $\begin{array}{l}\text { Distance to reach boundary closest to } \\
\text { reference location (m) }\end{array}$ & 0 & 30 & 63.8 & 99.8 & 128.8 & 157.8 \\
\hline Channel width at bank full (m) & 9.7 & 7.2 & 10.5 & 9.7 & 8.5 & 10.2 \\
\hline Left bank width (m) & 0 & 0 & 0 & 2.0 & 0 & 0 \\
\hline Right bank width (m) & 2.3 & 0 & 2.5 & 1.0 & 3.0 & 2.2 \\
\hline Left bank flood plain width (m) & $>50$ & $>50$ & $>50$ & $>50$ & $>50$ & $>50$ \\
\hline Right bank flood plain width (m) & $>50$ & $>50$ & $>50$ & $>50$ & $>50$ & $>50$ \\
\hline \multicolumn{7}{|c|}{ Depth at thalweg $(\mathrm{m})$} \\
\hline Point 1 & 0.80 & 1.35 & 1.00 & 0.60 & 0.80 & 0.68 \\
\hline Point 2 & .70 & 1.37 & 1.20 & .65 & .75 & .62 \\
\hline Point 3 & .70 & 1.04 & .90 & .67 & .52 & .60 \\
\hline \multicolumn{7}{|c|}{ Distance from left bank (m) } \\
\hline Point 1 & 1.7 & 1.3 & 2.7 & 2.5 & 1.3 & 2.8 \\
\hline Point 2 & 4.3 & 2.6 & 4.8 & 4.5 & 3.5 & 4.8 \\
\hline Point 3 & 6.6 & 4.7 & 7.2 & 6.6 & 5.0 & 6.4 \\
\hline Dominant bed substrate (point 1 ) & SA & OD & OD & OD & SI & OD \\
\hline Subdominant (point 1) & SI & SI & MU & SA & SA & SA \\
\hline Silt (point 1) & $\mathrm{Y}$ & $\mathrm{Y}$ & $\mathrm{Y}$ & $\mathrm{Y}$ & $\mathrm{Y}$ & $\mathrm{Y}$ \\
\hline Dominant (point 2) & OD & OD & OD & SA & SA & SA \\
\hline Subdominant (point 2) & SI & SI & MU & OD & SI & OD \\
\hline Silt (point 2) & $\mathrm{Y}$ & $\mathrm{Y}$ & $\mathrm{Y}$ & NO & $\mathrm{Y}$ & $\mathrm{N}$ \\
\hline Dominant (point 3) & OD & OD & OD & OD & OD & MU \\
\hline Subdominant (point 3) & SA & SI & MU & MU & MU & OD \\
\hline Silt (point 3) & $\mathrm{Y}$ & $\mathrm{Y}$ & $\mathrm{Y}$ & $\mathrm{Y}$ & $\mathrm{Y}$ & $\mathrm{Y}$ \\
\hline \multicolumn{7}{|c|}{ Embeddedness $^{a}$} \\
\hline Point 1 & 0 & 0 & 0 & 0 & 0 & 0 \\
\hline Point 2 & 0 & 0 & 0 & 0 & 0 & 0 \\
\hline Point 3 & 0 & 0 & 0 & 0 & 0 & 0 \\
\hline Left bank canopy (degrees) & 90 & 90 & 90 & 90 & 90 & 90 \\
\hline Right bank canopy (degrees) & 90 & 90 & 77 & 90 & 90 & 90 \\
\hline Canopy angle (degrees) & 0 & 0 & 13 & 0 & 0 & 0 \\
\hline Aspect $^{b}$ (degrees) & 210 & 190 & 173 & 171 & 190 & 160 \\
\hline \multicolumn{7}{|c|}{ Habitat features (type and percent of transect) } \\
\hline Woody snags & 50 & 0 & 10 & 25 & 25 & 15 \\
\hline Overhanging vegetation (terrestrial) & 0 & 35 & 5 & 25 & 25 & 0 \\
\hline Undercut banks & 0 & 0 & 0 & 0 & 0 & 0 \\
\hline Boulders & 0 & 0 & 0 & 0 & 0 & 0 \\
\hline Sloughs & 0 & 0 & 0 & 0 & 0 & 0 \\
\hline Macrophytes-emergent & 0 & 0 & 0 & 0 & 0 & 50 \\
\hline Macrophytes-submerged & 0 & 0 & 0 & 0 & 0 & 0 \\
\hline Macrophytes-floating & 0 & 0 & 0 & 0 & 0 & 0 \\
\hline Rubbish & 0 & 0 & 0 & 0 & 0 & 0 \\
\hline Other & 0 & 0 & 0 & 0 & 0 & 0 \\
\hline
\end{tabular}

${ }^{a}$ Embeddedness is a numerical rating that describes the extent to which coarse material, such as boulders, cobbles, and bedrock, is covered by fine material (sand, silt, fine particulate organic matter). An embeddedness rating of zero (0) indicates that no coarse material is visible.

${ }^{\mathrm{b}}$ Aspect is the direction of streamflow at the center of the transect (degrees, magnetic). 
Appendix 7. Habitat characterization and site descriptions-Continued

\section{MYERS CREEK (Continued)}

[T-n, transect number; m, meters; >, greater than; OD, organic detritus; MU, muck; SA, sand; SI, silt; I, island; $Y$, yes; NO, none; NA, not applicable. Referring to bank shape: LN, linear; CC, concave; CV, convex. Referring to bank erosion: CB, undercut bank; SL, slab failure; RO rotational failure]

\begin{tabular}{|c|c|c|c|c|c|c|}
\hline Habitat characteristic & T-1 & T-2 & T-3 & T-4 & T-5 & T-6 \\
\hline \multicolumn{7}{|c|}{ Bar/Shelf/Island } \\
\hline Type point 1 & NO & NO & NO & NO & NO & $\mathrm{I}$ \\
\hline Width at point $1(\mathrm{~m})$ & NA & NA & NA & NA & NA & 2.5 \\
\hline Substrate (dominant) point 1 & NA & NA & NA & NA & NA & SI \\
\hline Substrate (subdominant) point 1 & NA & NA & NA & NA & NA & SA \\
\hline Woody vegetation cover point 1 (percent) & NA & NA & NA & NA & NA & 0 \\
\hline $\begin{array}{l}\text { Herbaceous vegetation cover point } 1 \\
\text { (percent) }\end{array}$ & NA & NA & NA & NA & NA & 100 \\
\hline Type point 2 & NO & NO & NO & NO & NO & NO \\
\hline Type point 3 & NO & NO & NO & NO & NO & NO \\
\hline \multicolumn{7}{|c|}{ Bank parameters } \\
\hline Left bank height (m) & 1.0 & 1.40 & 1.5 & 0.72 & 0.96 & 0.79 \\
\hline Right bank height (m) & .6 & 1.40 & 1.4 & .73 & .93 & .77 \\
\hline Left bank vegetation stability & 3 & 3 & 3 & 2 & 3 & 3 \\
\hline Left bank shape & LN & $\mathrm{LN}$ & LN & $\mathrm{CC}$ & LN & $\mathrm{LN}$ \\
\hline Left bank erosion & NO & NO & NO & NO & NO & NO \\
\hline Right bank vegetation stability & 1 & 1 & 1 & 2 & 2 & 4 \\
\hline Right bank shape & $\mathrm{CC}$ & $\mathrm{CC}$ & $\mathrm{CC}$ & $\mathrm{CC}$ & $\mathrm{CC}$ & $\mathrm{CC}$ \\
\hline Right bank erosion & NO & $\mathrm{CB}$ & NO & NO & NO & NO \\
\hline Left bank dominant substrate & SI & SA & SA & SA & SA & SA \\
\hline Left bank subdominant substrate & SA & SI & SI & SI & SI & SI \\
\hline Right bank dominant substrate & SI & SI & SI & SA & SA & SI \\
\hline Right bank subdominant substrate & SA & NO & SA & SI & SI & SA \\
\hline
\end{tabular}


Appendix 7. Habitat characterization and site descriptions-Continued

\section{CEDAR CREEK}

[T-n, transect number; m, meters; >, greater than; OD, organic detritus; MU, muck; SA, sand; SI, silt; I, island; Y, yes; NO, none; NA, not applicable. Referring to bank shape: LN, linear; CC, concave; CV, convex. Referring to bank erosion: CB, undercut bank; SL, slab failure; RO rotational failure]

\begin{tabular}{|c|c|c|c|c|c|c|}
\hline Habitat characteristic & $\mathrm{T}-1$ & T-2 & T-3 & $\mathrm{T}-4$ & T-5 & $\mathrm{T}-6$ \\
\hline $\begin{array}{l}\text { Distance to reach boundary closest to } \\
\text { reference location (m) }\end{array}$ & 0 & 35 & 74 & 103 & 137 & 168 \\
\hline Channel width at bank full (m) & 6.4 & 7.8 & 6.8 & 7.1 & 8.0 & 6.6 \\
\hline Left bank width (m) & 0 & 0 & 0 & 0 & 0 & 0 \\
\hline Right bank width (m) & 0 & 0 & 0 & 1.6 & 1.0 & 0 \\
\hline Left bank flood plain width (m) & $>50$ & $>50$ & $>50$ & $>50$ & $>50$ & $>50$ \\
\hline Right bank flood plain width (m) & $>50$ & $>50$ & $>50$ & $>50$ & $>50$ & $>50$ \\
\hline \multicolumn{7}{|c|}{ Depth at thalweg $(\mathrm{m})$} \\
\hline Point 1 & 1.28 & 0.92 & 0.94 & 01.62 & 0.90 & 1.12 \\
\hline Point 2 & 1.36 & 1.34 & 1.24 & 1.20 & 1.30 & 1.50 \\
\hline Point 3 & 1.06 & .74 & 1.34 & .82 & 1.62 & 1.16 \\
\hline \multicolumn{7}{|c|}{ Distance from left bank (m) } \\
\hline Point 1 & 1.6 & 1.9 & 2.3 & 2.3 & 2.8 & 2.0 \\
\hline Point 2 & 3.0 & 4.3 & 4.3 & 3.4 & 5.0 & 3.6 \\
\hline Point 3 & 4.5 & 6.0 & 6.2 & 4.9 & 6.4 & 4.6 \\
\hline Dominant bed substrate (point 1 ) & SA & SA & SA & SA & SA & SA \\
\hline Subdominant (point 1) & NO & NO & OD & OD & OD & OD \\
\hline Silt (point 1) & NO & NO & NO & NO & $\mathrm{NO}$ & NO \\
\hline Dominant (point 2) & SA & SA & SA & SA & SA & SA \\
\hline Subdominant (point 2) & NO & NO & OD & OD & OD & OD \\
\hline Silt (point 2) & NO & NO & NO & NO & NO & NO \\
\hline Dominant (point 3) & SA & SA & $\mathrm{SA}$ & SA & SA & SA \\
\hline Subdominant (point 3) & NO & NO & OD & OD & OD & OD \\
\hline Silt (point 3) & NO & NO & NO & $\mathrm{NO}$ & $\mathrm{NO}$ & NO \\
\hline \multicolumn{7}{|c|}{ Embeddedness $^{\mathrm{a}}$} \\
\hline Point 1 & 0 & 0 & 0 & 0 & 0 & 0 \\
\hline Point 2 & 0 & 0 & 0 & 0 & 0 & 0 \\
\hline Point 3 & 0 & 0 & 0 & 0 & 0 & 0 \\
\hline Left bank canopy (degrees) & 70 & 90 & 85 & 90 & 75 & 90 \\
\hline Right bank canopy (degrees) & 90 & 90 & 63 & 90 & 80 & 90 \\
\hline Canopy angle (degrees) & 20 & 0 & 32 & 0 & 25 & 0 \\
\hline Aspect $^{\mathrm{b}}$ (degrees) & 240 & 260 & 280 & 300 & 187 & 330 \\
\hline \multicolumn{7}{|c|}{ Habitat features (type and percent of transect) } \\
\hline Woody snags & 0 & 20 & 50 & 20 & 20 & 25 \\
\hline Overhanging vegetation (terrestrial) & 50 & 75 & 25 & 75 & 25 & 100 \\
\hline Undercut banks & 0 & 0 & 0 & 0 & 0 & 0 \\
\hline Boulders & 0 & 0 & 0 & 0 & 0 & 0 \\
\hline Sloughs & 0 & 0 & 0 & 0 & 0 & 0 \\
\hline Macrophytes-emergent & 0 & 0 & 0 & 0 & 0 & 0 \\
\hline Macrophytes-submerged & 0 & 0 & 0 & 0 & 0 & 0 \\
\hline Macrophytes-floating & 0 & 0 & 0 & 0 & 0 & 0 \\
\hline Rubbish & 0 & 0 & 0 & 0 & 0 & 0 \\
\hline Other & 0 & 0 & 0 & 0 & 0 & 0 \\
\hline
\end{tabular}

${ }^{a}$ Embeddedness is a numerical rating that describes the extent to which coarse material, such as boulders, cobbles, and bedrock, is covered by fine material (sand, silt, fine particulate organic matter). An embeddedness rating of zero ( 0 ) indicates that no coarse material is visible.

${ }^{\mathrm{b}}$ Aspect is the direction of streamflow at the center of the transect (degrees, magnetic). 
Appendix 7. Habitat characterization and site descriptions-Continued

\section{CEDAR CREEK (Continued)}

[T-n, transect number; $m$, meters; >, greater than; OD, organic detritus; MU, muck; SA, sand; SI, silt; I, island; $Y$, yes; NO, none; NA, not applicable. Referring to bank shape: LN, linear; CC, concave; CV, convex. Referring to bank erosion: CB, undercut bank; SL, slab failure; RO rotational failure]

\begin{tabular}{|c|c|c|c|c|c|c|}
\hline Habitat characteristic & $\mathrm{T}-1$ & T-2 & T-3 & $\mathrm{T}-4$ & T-5 & T-6 \\
\hline \multicolumn{7}{|c|}{ Bank parameters } \\
\hline Left bank height (m) & 1.44 & 1.36 & 1.40 & 1.82 & 1.64 & 1.78 \\
\hline Right bank height (m) & 1.46 & 1.2 & 1.41 & 1.80 & 1.66 & 1.64 \\
\hline Left bank vegetation stability & 4 & 4 & 4 & 4 & 3 & 4 \\
\hline Left bank shape & LN & $\mathrm{LN}$ & $\mathrm{LN}$ & $\mathrm{LN}$ & $\mathrm{LN}$ & $\mathrm{LN}$ \\
\hline Left bank erosion & NO & NO & NO & NO & NO & NO \\
\hline Right bank vegetation stability & 4 & 4 & 4 & 4 & 4 & 4 \\
\hline Right bank shape & $\mathrm{LN}$ & $\mathrm{LN}$ & $\mathrm{LN}$ & $\mathrm{LN}$ & $\mathrm{LN}$ & $\mathrm{LN}$ \\
\hline Right bank erosion & NO & NO & NO & NO & NO & NO \\
\hline Left bank dominant substrate & SA & SA & SA & SA & SA & SA \\
\hline Left bank subdominant substrate & OD & OD & OD & OD & OD & OD \\
\hline Right bank dominant substrate & SA & SA & SA & SA & SA & SA \\
\hline Right bank subdominant substrate & OD & OD & OD & OD & OD & OD \\
\hline
\end{tabular}




\section{CEDAR CREEK NEAR WISE LAKE}

[T-n, transect number; m, meters; >, greater than; OD, organic detritus; MU, muck; SA, sand; SI, silt; I, island; $\mathrm{Y}$, yes; NO, none; NA, not applicable. Referring to bank shape: LN, linear; CC, concave; CV, convex. Referring to bank erosion: CB, undercut bank; SL, slab failure; RO rotational failure]

\begin{tabular}{|c|c|c|c|c|c|c|}
\hline Habitat characteristic & $\mathrm{T}-1$ & T-2 & T-3 & T-4 & T-5 & $\mathrm{T}-6$ \\
\hline $\begin{array}{l}\text { Distance to reach boundary closest to } \\
\text { reference location }(\mathrm{m})\end{array}$ & 0 & 47.00 & 99.70 & 144.70 & 219.70 & 271.20 \\
\hline Channel width at bank full (m) & 36.00 & 36.00 & 36.60 & 40.00 & 43.00 & 37.00 \\
\hline Left bank width (m) & .00 & 3.90 & 3.20 & 9.00 & 7.00 & 8.00 \\
\hline Right bank width (m) & 5.30 & 3.50 & .60 & .00 & 21.30 & .00 \\
\hline Left bank flood plain width (m) & $>50$ & $>50$ & $>50$ & $>50$ & $>50$ & $>50$ \\
\hline Right bank flood plain width (m) & $>50$ & $>50$ & $>50$ & $>50$ & $>50$ & $>50$ \\
\hline \multicolumn{7}{|c|}{ Depth at thalweg (m) } \\
\hline Point 1 & 1.64 & 0.20 & 0.40 & 0.06 & 0.37 & 0.20 \\
\hline Point 2 & 1.46 & .82 & .38 & .14 & .96 & .48 \\
\hline Point 3 & .58 & 1.60 & 1.52 & 1.70 & 1.78 & 1.60 \\
\hline \multicolumn{7}{|c|}{ Distance from left bank (m) } \\
\hline Point 1 & 4.0 & 9.0 & 10.0 & 10.0 & 7.5 & 15.0 \\
\hline Point 2 & 7.0 & 18.0 & 20.0 & 20.0 & 11.0 & 23.0 \\
\hline Point 3 & 26.0 & 24.0 & 30.0 & 33.0 & 17.0 & 31.0 \\
\hline Dominant bed substrate (point 1 ) & OD & OD & OD & OD & OD & OD \\
\hline Subdominant (point 1) & SA & NO & SI & SI & SI & SI \\
\hline Silt (point 1$)$ & $\mathrm{Y}$ & $\mathrm{Y}$ & $\mathrm{Y}$ & $\mathrm{Y}$ & $\mathrm{Y}$ & $\mathrm{Y}$ \\
\hline Dominant (point 2) & OD & OD & OD & OD & OD & OD \\
\hline Subdominant (point 2) & SA & NO & SI & SI & SI & SI \\
\hline Silt (point 2) & $\mathrm{Y}$ & $\mathrm{Y}$ & $\mathrm{Y}$ & $\mathrm{Y}$ & $\mathrm{Y}$ & $\mathrm{Y}$ \\
\hline Dominant (point 3) & OD & OD & $\mathrm{OD}$ & $\mathrm{OD}$ & OD & OD \\
\hline Subdominant (point 3) & SA & $\mathrm{NO}$ & SI & SI & SI & SI \\
\hline Silt (point 3) & $\mathrm{Y}$ & $\mathrm{Y}$ & Y & $\mathrm{Y}$ & $\mathrm{Y}$ & $\mathrm{Y}$ \\
\hline \multicolumn{7}{|c|}{ Embeddedness $^{\mathrm{a}}$} \\
\hline Point 1 & 0 & 0 & 0 & 0 & 0 & 0 \\
\hline Point 2 & 0 & 0 & 0 & 0 & 0 & 0 \\
\hline Point 3 & 0 & 0 & 0 & 0 & 0 & 0 \\
\hline Left bank canopy (degrees) & 90 & 80 & 90 & 60 & 60 & 80 \\
\hline Right bank canopy (degrees) & 80 & 90 & 55 & 90 & 70 & 75 \\
\hline Canopy angle (degrees) & 10 & 10 & 35 & 30 & 50 & 25 \\
\hline Aspect ${ }^{b}$ (degrees) & 205 & 115 & 110 & 85 & 200 & 87 \\
\hline \multicolumn{7}{|c|}{ Habitat features (type and percent of transect) } \\
\hline Woody snags & 0 & 10 & 40 & 10 & 50 & 20 \\
\hline Overhanging vegetation (terrestrial) & 50 & 10 & 10 & 0 & 20 & 10 \\
\hline Undercut banks & 0 & 0 & 0 & 0 & 0 & 0 \\
\hline Boulders & 0 & 0 & 0 & 0 & 0 & 0 \\
\hline Sloughs & 0 & 0 & 0 & 0 & 0 & 0 \\
\hline Macrophytes-emergent & 0 & 0 & 0 & 0 & 0 & 0 \\
\hline Macrophytes-submerged & 0 & 0 & 0 & 0 & 0 & 0 \\
\hline Macrophytes-floating & 0 & 0 & 0 & 0 & 0 & 0 \\
\hline Rubbish & 0 & 0 & 0 & 0 & 0 & 0 \\
\hline Other & 0 & 0 & 0 & 0 & 0 & 0 \\
\hline
\end{tabular}

${ }^{a}$ Embeddedness is a numerical rating that describes the extent to which coarse material, such as boulders, cobbles, and bedrock, is covered by fine material (sand, silt, fine particulate organic matter). An embeddedness rating of zero (0) indicates that no coarse material is visible.

${ }^{\mathrm{b}}$ Aspect is the direction of streamflow at the center of the transect (degrees, magnetic). 
Appendix 7. Habitat characterization and site descriptions-Continued

\section{CEDAR CREEK NEAR WISE LAKE (Continued)}

[T-n, transect number; m, meters; >, greater than; OD, organic detritus; MU, muck; SA, sand; SI, silt; I, island; Y, yes; NO, none; NA, not applicable. Referring to bank shape: $\mathrm{LN}$, linear; CC, concave; CV, convex. Referring to bank erosion: $\mathrm{CB}$, undercut bank; SL, slab failure; RO rotational failure]

\begin{tabular}{|c|c|c|c|c|c|c|}
\hline Habitat characteristic & $T-1$ & T-2 & $\mathrm{T}-3$ & $\mathrm{~T}-4$ & T-5 & T-6 \\
\hline \multicolumn{7}{|c|}{ Bar/Shelf/Island } \\
\hline Type point 1 & I & NO & NO & NO & NO & NO \\
\hline Width point $1(\mathrm{~m})$ & 9.5 & NA & NA & NA & NA & NA \\
\hline Substrate (dominant) point 1 & SI & NA & NA & NA & NA & NA \\
\hline Substrate (subdominant) point 1 & SI & NA & NA & NA & NA & NA \\
\hline Woody vegetation cover point 1 (percent) & 80 & NA & NA & NA & NA & NA \\
\hline $\begin{array}{l}\text { Herbaceous vegetation cover point } 1 \\
\text { (percent) }\end{array}$ & 80 & NA & NA & NA & NA & NA \\
\hline \multicolumn{7}{|c|}{ Bank parameters } \\
\hline Left bank angle (degrees) & 90 & 19 & 22 & 5 & 7 & 11 \\
\hline Right bank angle (degrees) & 23 & 23 & 90 & 90 & 8 & 90 \\
\hline Left bank height (m) & 2.89 & 2.69 & 2.28 & 2.19 & 2.64 & 2.56 \\
\hline Right bank height (m) & 1.99 & 2.32 & 2.7 & 2.38 & 1.93 & 3.00 \\
\hline Left bank vegetation stability & 3 & 4 & 3 & 4 & 3 & 3 \\
\hline Left bank shape & $\mathrm{LN}$ & $\mathrm{CC}$ & $\mathrm{CC}$ & $\mathrm{CC}$ & $\mathrm{CC}$ & $\mathrm{CC}$ \\
\hline Left bank erosion & $\mathrm{CB}$ & NO & $\mathrm{NO}$ & NO & NO & NO \\
\hline Right bank vegetation stability & 2 & 3 & 2 & 1 & 4 & 1 \\
\hline Right bank shape & $\mathrm{CC}$ & $\mathrm{CC}$ & $\mathrm{LN}$ & $\mathrm{LN}$ & $\mathrm{CC}$ & $\mathrm{LN}$ \\
\hline Right bank erosion & NO & NO & SL & SL & NO & SL \\
\hline Left bank dominant substrate & SI & SI & SI & SI & SI & SI \\
\hline Left bank subdominant substrate & NO & NO & NO & NO & NO & $\mathrm{NO}$ \\
\hline Right bank dominant substrate & SA & SI & SI & SI & SI & SI \\
\hline Right bank subdominant substrate & SI & NO & NO & NO & NO & NO \\
\hline
\end{tabular}




\section{TOMS CREEK}

[T-n, transect number; m, meters; >, greater than; OD, organic detritus; MU, muck; SA, sand; SI, silt; I, island; Y, yes; NO, none; NA, not applicable. Referring to bank shape: LN, linear; CC, concave; CV, convex. Referring to bank erosion: CB, undercut bank; SL, slab failure; RO rotational failure]

\begin{tabular}{|c|c|c|c|c|c|c|}
\hline Habitat characteristic & $\mathrm{T}-1$ & T-2 & T-3 & T-4 & T-5 & T-6 \\
\hline $\begin{array}{l}\text { Distance to reach boundary closest to } \\
\text { reference location }(\mathrm{m})\end{array}$ & 0 & 30.3 & 65.9 & 97.0 & 124.0 & 155.0 \\
\hline Channel width at bank full (m) & 6.7 & 6.0 & 5.6 & 6.6 & 8.3 & 7.0 \\
\hline Left bank width (m) & 0 & 0 & 0 & 0 & 0 & 0 \\
\hline Right bank width (m) & 0 & 0 & 0 & 0 & 0 & 0 \\
\hline Left bank flood plain width (m) & $>50$ & $>50$ & $>50$ & $>50$ & $>50$ & $>50$ \\
\hline Right bank flood plain width (m) & $>50$ & $>50$ & $>50$ & $>50$ & $>50$ & $>50$ \\
\hline \multicolumn{7}{|c|}{ Depth at thalweg (m) } \\
\hline Point 1 & 0.64 & 1.00 & 0.64 & 0.74 & 0.38 & 0.88 \\
\hline Point 2 & .6 & .50 & .76 & .58 & .48 & .74 \\
\hline Point 3 & .52 & .40 & .54 & .30 & .64 & .40 \\
\hline \multicolumn{7}{|c|}{ Distance from left bank (m) } \\
\hline Point 1 & 1.4 & 2 & 1.6 & 2.2 & 2.3 & 2.2 \\
\hline Point 2 & 3.0 & 3.5 & 2.8 & 3.5 & 4.5 & 3.5 \\
\hline Point 3 & 4.6 & 4.7 & 4.2 & 4.7 & 7.1 & 5.0 \\
\hline Dominant bed substrate (point 1 ) & SA & SA & SA & SA & SA & SA \\
\hline Subdominant (point 1) & SI & SI & SI & SI & NO & $\mathrm{NO}$ \\
\hline Silt (point 1) & $\mathrm{Y}$ & $\mathrm{Y}$ & $\mathrm{Y}$ & $\mathrm{Y}$ & $\mathrm{Y}$ & NO \\
\hline Dominant (point 2) & SA & SA & SA & SA & SA & SA \\
\hline Subdominant (point 2) & SI & SI & SI & SI & NO & NO \\
\hline Silt (point 2) & $\mathrm{Y}$ & $\mathrm{Y}$ & $\mathrm{Y}$ & $\mathrm{Y}$ & $\mathrm{Y}$ & NO \\
\hline Dominant (point 3) & SA & SA & SA & SA & SA & SA \\
\hline Subdominant (point 3) & SI & SI & SI & SI & NO & NO \\
\hline Silt (point 3) & Y & $\mathrm{Y}$ & $\mathrm{Y}$ & $\mathrm{Y}$ & $\mathrm{Y}$ & $\mathrm{NO}$ \\
\hline \multicolumn{7}{|c|}{ Embeddedness $^{\mathrm{a}}$} \\
\hline Point 1 & 0 & 0 & 0 & 0 & 0 & 0 \\
\hline Point 2 & 0 & 0 & 0 & 0 & 0 & 0 \\
\hline Point 3 & 0 & 0 & 0 & 0 & 0 & 0 \\
\hline Left bank canopy (degrees) & 90 & 90 & 90 & 90 & 90 & 90 \\
\hline Right bank canopy (degrees) & 90 & 75 & 70 & 80 & 85 & 90 \\
\hline Canopy angle (degrees) & 0 & 15 & 20 & 10 & 5 & 0 \\
\hline Aspect $^{\mathrm{b}}$ (degrees) & 120 & 177 & 187 & 190 & 230 & 255 \\
\hline \multicolumn{7}{|c|}{ Habitat features (type and percent of transect) } \\
\hline Woody snags & 20 & 35 & 50 & 10 & 30 & 10 \\
\hline Overhanging vegetation (terrestrial) & 0 & 0 & 0 & 0 & 0 & 0 \\
\hline Undercut banks & 0 & 0 & 0 & 0 & 0 & 0 \\
\hline Boulders & 0 & 0 & 0 & 0 & 0 & 0 \\
\hline Sloughs & 0 & 0 & 0 & 0 & 0 & 0 \\
\hline Macrophytes-emergent & 0 & 0 & 0 & 0 & 0 & 0 \\
\hline Macrophytes-submerged & 0 & 0 & 0 & 0 & 0 & 0 \\
\hline Macrophytes-floating & 0 & 0 & 0 & 0 & 0 & 0 \\
\hline Rubbish & 0 & 0 & 0 & 0 & 0 & 0 \\
\hline Other & 0 & 0 & 0 & 0 & 0 & 0 \\
\hline
\end{tabular}

${ }^{a}$ Embeddedness is a numerical rating that describes the extent to which coarse material, such as boulders, cobbles, and bedrock, is covered by fine material (sand, silt, fine particulate organic matter). An embeddedness rating of zero (0) indicates that no coarse material is visible.

${ }^{\mathrm{b}}$ Aspect is the direction of streamflow at the center of the transect (degrees, magnetic). 
Appendix 7. Habitat characterization and site descriptions-Continued

\section{TOMS CREEK (Continued)}

[T-n, transect number; m, meters; >, greater than; OD, organic detritus; MU, muck; SA, sand; SI, silt; I, island; Y, yes; NO, none; NA, not applicable. Referring to bank shape: LN, linear; CC, concave; CV, convex. Referring to bank erosion: CB, undercut bank; SL, slab failure; RO rotational failure]

\begin{tabular}{|c|c|c|c|c|c|c|}
\hline Habitat characteristic & $\mathrm{T}-1$ & T-2 & T-3 & T-4 & T-5 & T-6 \\
\hline \multicolumn{7}{|c|}{ Bank parameters } \\
\hline Left bank height (m) & 0.99 & 1.39 & 0.87 & 1.11 & 0.99 & 1.60 \\
\hline Right bank height (m) & .86 & 1.14 & .96 & .87 & .87 & 1.15 \\
\hline Left bank vegetation stability & 3 & 4 & 4 & 4 & 4 & 5 \\
\hline Left bank shape & $\mathrm{CC}$ & LN & LN & $\mathrm{LN}$ & $\mathrm{LN}$ & LN \\
\hline Left bank erosion & NO & NO & СВ & CB & CB & CB \\
\hline Right bank vegetation stability & 3 & 3 & 3 & 3 & 4 & 5 \\
\hline Right bank shape & $\mathrm{CC}$ & $\mathrm{CC}$ & $\mathrm{CC}$ & $\mathrm{CC}$ & $\mathrm{CC}$ & $\mathrm{CC}$ \\
\hline Right bank erosion & NO & NO & NO & NO & NO & NO \\
\hline Left bank dominant substrate & SI & SI & SI & SI & SA & SA \\
\hline Left bank subdominant substrate & SA & SA & SA & SA & SI & SI \\
\hline Right bank dominant substrate & SI & SI & SI & SI & SA & SA \\
\hline Right bank subdominant substrate & SA & SA & SA & SA & SI & SI \\
\hline
\end{tabular}


Appendix 7. Habitat characterization and site descriptions-Continued

\section{Site descriptions}

$[\mathrm{m}$, meters]

\section{CONGAREE RIVER AT COLUMBIA}

USGS downstream order number: 02169500

The bed-sediment and tissue collections were conducted at the confluence of the Saluda and the Broad Rivers at the Gervais Street Bridge in Columbia. Fish collections and algae/macroinvertebrate collections were accomplished within a designated reach of the river, commencing at the Barney Jordan Public Boat Landing and extending to the Blossom Street Bridge. The reach is 2,896 m in length along the right bank and 3,050 m long along the left bank, and 130 to $190 \mathrm{~m}$ in width. Macroinvertebrates and algae were collected from submerged logs along the banks, from rocks in a wadeable section downstream of the railroad bridge along the left bank, and from willow (Salix sp.) branches trailing in the water. The habitat presented by tree branches in the Congaree River has been documented by Patrick (1996). Two impoundments in the Saluda River upstream of the site, Lakes Murray and Greenwood, and an impoundment on the Broad River (Monticello Reservoir) eliminate stable shallow water habitats by causing unpredictable daily changes in river stage. The changes in river stage periodically flush the reach and remove woody snags and debris dams. In addition, sediments transported by the Broad River tend to smother benthic habitats during periods of low flow.

\section{MYERS CREEK}

USGS downstream order number: 02169660

This site is located upstream of the bridge on Secondary State Route (SSR) 734 near Hopkins, S.C. It is at the northwestern boundary of the Congaree Swamp National Monument. The reach begins $40 \mathrm{~m}$ upstream of the bridge and extends for $158 \mathrm{~m}$ upstream.

Approximate position of start of reach is latitude $33^{\circ} 50^{\prime} 27^{\prime \prime}$, longitude $80^{\circ} 51^{\prime} 36^{\prime \prime}$.

Transect 1 (T-1) is the beginning of the reach and is marked with a spike driven into the inboard side of the trunk of a sweet gum (Liriodendron styraciflua) tree, about 3 feet up from the bank-full point, on the left bank. Bank-full channel width is $9.7 \mathrm{~m}$.

Transect 2 (T-2) is $30 \mathrm{~m}$ upstream of T-1. It is marked with a "2" on the inboard side of the trunk of a Liriodendron styraciflua on the left bank. The channel width (bank full to bank full) is $7.2 \mathrm{~m}$.

Transect 3 (T-3) is $33.8 \mathrm{~m}$ upstream of T-2. A red maple (Acer rubrum) has here been marked with a "3" on the inboard side of its trunk at breast height. At this site, a large, blown down tree (blowdown) bridges the stream (bridging blowdown) just upstream of the transect. Channel width is $10.5 \mathrm{~m}$.

Transect 4 (T-4) is $36 \mathrm{~m}$ upstream of T-3 (99.8 m upstream of T-1). It is marked with the number "4" painted on the inboard side of the largest of three Acer rubrum trees growing in a close clump on the left bank. Immediately upstream of T-4 are two bridging blowdowns. Directly opposite the marked A. rubrum, are three Tupelos (Nyssa aquatica) growing side by side on the right bank.

Transect 5 (T-5), marked with the number "5" painted on the inboard side of a dual-trunk sweetgum, Liriodendron styraciflua, on the left bank, is $29 \mathrm{~m}$ upstream of T-4. At this site there is a small bed of aquatic macrophytes. On the right side of the stream is a slough that becomes a channel during high water and creates a small island. Another blowdown extends from the left bank to the downstream tip of the island.

Transect 6 (T-6) is $29 \mathrm{~m}$ upstream of T-5 and $157.8 \mathrm{~m}$ upstream of T-1. The marker for this transect is a multi-trunk Acer rubrum with a "6" painted on the inboard side and a spike driven into the trunk below the number. The spike has a piece of orange tree-tape tied around it. There is a large bed of aquatic macrophytes within the transect. 
Appendix 7. Habitat characterization and site descriptions-Continued

\section{CEDAR CREEK, RICHLAND COUNTY, S.C.}

USGS downstream order number: 02169670

This site is located just upstream of the bridge on SSR 734 near Hopkins, S.C., and is at the northwest corner of the Congaree

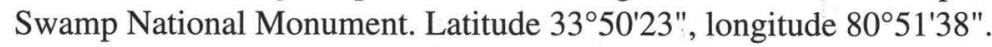

The reach commences $37 \mathrm{~m}$ upstream of the bridge and extends for a total length of $168 \mathrm{~m}$. This is a second order stream resulting from the confluence of Cedar Creek and Reedy Branch about $550 \mathrm{~m}$ upstream of the beginning of the study reach. On Cedar Creek about $50 \mathrm{~m}$ upstream of the confluence is Duffies Pond. This impoundment of approximately 20 acres $\left(0.083 \mathrm{~km}^{2}\right)$ is the result of damming Cedar Creek and provides a steady flow to Cedar Creek.

The first of 6 transects (T-1) coincides with the beginning (downstream end) of the reach. It is marked by a spike driven into the inboard side of the trunk of a sweet gum tree (Liquidambar styraciflua) on the right bank.

Transect 2 (T-2) is $35 \mathrm{~m}$ upstream of T-1 (72 m from the bridge) and is marked with a painted "2" on the trunk of a sweet gum tree (L. styraciflua) on the left bank, and a white blotch on the trunk of an overhanging red bay (Persea borbonia) inboard of the gum tree.

Transect 3 (T-3) is $39 \mathrm{~m}$ upstream from T-2 (111 m from the bridge). Marked with a painted " 3 " on the downstream side of a bridging $L$. styraciflua on the right bank.

Transect 4 (T-4) is $29 \mathrm{~m}$ upstream of T-3 (140 m from the bridge). Marked by a painted " 4 " on the inboard side of a red maple (Acer rubrum) that overhangs the stream from the left bank.

Transect 5 (T-5) is $34 \mathrm{~m}$ upstream of T-4 (174 m from the bridge). Marked by a painted number " 5 "on a maple (Acer sp.) tree on the left bank.

Transect 6 (T-6) is $31 \mathrm{~m}$ upstream of T-5 (205 m from the bridge). Marked with a painted " 6 " on the trunk of a L. styraciflua on the right bank and a spike in the inboard side of the trunk. 
Appendix 7. Habitat characterization and site descriptions-Continued

\section{CEDAR CREEK NEAR WISE LAKE}

USGS downstream order number: 02169672

The site is located inside the Congaree Swamp National Monument at the Hunt Club. The study reach commences at the

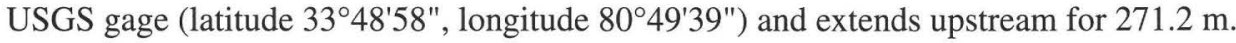

Transect 1 (T-1) commences approximately $2 \mathrm{~m}$ upstream of the USGS gage on the left bank. A red tree flag marks the right bank, tied about a tree stump with the number " 1 " painted in white on the inboard side.

Transect 2 (T-2 ) is $47 \mathrm{~m}$ upstream of T-1. Right bank marker is an ironwood tree (Carpinus caroliniana) with orange flagging and the number " 2 " painted on the inboard side of the trunk.

Transect 3 (T-3) is $52.7 \mathrm{~m}$ upstream of T-2. Right bank marker is orange flagging on an ironwood tree (C. caroliniana) with the number " 3 " painted in white on the inboard side of the tree trunk.

Transect 4 (T-4) is 45.0 m upstream of T-3. Right bank marker is orange flagging around an oak tree (Quercus sp.) with the number " 4 " painted in white on inboard side of the tree trunk.

Transect 5 (T-5) is $75 \mathrm{~m}$ upstream of T-4. Right bank marker is dead tree with orange flagging and the number " 5 " painted in white on inboard side.

Transect 6 (T-6) is 51.5 m upstream of T-5. Orange flagging around Carpinus caroliniana on right bank, and the number "6" is painted in white on inboard side. Left bank marker is a spike in downstream side of a gum (L. styraciflua) at breast height.

\section{TOMS CREEK NEAR GADSDEN, S.C.}

USGS downstream order number: 021696966

The Toms Creek site is located in Richland County, S.C. Take S.C. 48 southeast of Columbia toward the Wateree River. Turn right on SSR 489. Proceed for approximately $2.6 \mathrm{mi}$., turn right on dirt road, cross railroad tracks. Go straight at road split until you cross the stream. Bridge is dirt road over three drainage culverts. The bridge is the permanent reference point for this site, at latitude $33^{\circ} 48^{\prime} 42^{\prime \prime}$, longitude $80^{\circ} 43^{\prime} 31^{\prime \prime}$. The $150 \mathrm{~m}$-long study site commences approximately $59 \mathrm{~m}$ upstream of the bridge.

The reach commences at transect 1 (T-1) 59 m upstream of the reference point. Marked with a spike in the inboard side of a red maple (A. rubrum) on the left bank.

Transect 2 (T-2) is located $30.3 \mathrm{~m}$ upstream of T-1, marked by blue tree tape on a small red maple (Acer rubrum) on the right bank, and a spray-painted white blotch and the number " 2 " on the trunk.

Transect 3 (T-3) is $35.6 \mathrm{~m}$ upstream of T-2, marked by a twin tupelo on the left bank, with "T3" painted on the trunk and blue tape tied to trunk.

Transect 4 (T-4) is $31.1 \mathrm{~m}$ upstream of T-3, with "T4" painted on trunk of a tupelo (N. aquatica) on left bank and blue tree tape tied around trunk.

Transect 5 (T-5) is $27 \mathrm{~m}$ upstream of T-4, with "T5" painted on small gum tree (L. styraciflua) on the right bank and blue tape around the tree trunk.

Transect 6 (T-6) is $31 \mathrm{~m}$ upstream of T-5, with "T6" painted on the trunk of a tupelo (N. aquatica) on the right bank. This is the end of the reach; also marked with a white-painted spike driven into the inboard side of the trunk. 
Appendix 8. Macroinvertebrate fauna density

[Organsims per square meter of substrate - , not found]

\begin{tabular}{|c|c|c|c|c|c|}
\hline Macroinvertebrate taxa & $\begin{array}{c}\text { Congaree } \\
\text { River } \\
\text { at Columbia }\end{array}$ & $\begin{array}{l}\text { Myers } \\
\text { Creek }\end{array}$ & $\begin{array}{l}\text { Cedar } \\
\text { Creek }\end{array}$ & $\begin{array}{c}\text { Cedar Creek } \\
\text { near Wise Lake }\end{array}$ & $\begin{array}{l}\text { Toms } \\
\text { Creek }\end{array}$ \\
\hline Acari & - & 118 & 94 & 115 & 70 \\
\hline Amphipoda & - & - & 2 & - & - \\
\hline Bryozoa & - & - & 2 & - & - \\
\hline Collembola & - & - & 11 & - & - \\
\hline Hemiptera & - & & - & 325 & - \\
\hline Hirudinea & - & - & - & 29 & - \\
\hline Insecta - Coleoptera - Elmidae & 53 & 118 & 177 & 10 & 427 \\
\hline Insecta - Coleoptera - Gyrinidae & - & 94 & 109 & 5 & 4 \\
\hline Insecta - Coleoptera - Hydrophilidae & - & - & - & 5 & - \\
\hline Insecta - Diptera - Ceratopogonidae & 11 & 25 & - & 115 & 18 \\
\hline Insecta - Diptera - Chironomidae & 1,188 & 4,055 & 2,149 & 7,855 & 1,293 \\
\hline Insecta - Diptera - Empididae & 53 & 262 & 77 & - & 95 \\
\hline Insecta - Diptera - Simuliidae & 11 & 104 & 324 & - & 43 \\
\hline Insecta - Diptera - Tipulidae & 32 & - & - & - & - \\
\hline Insecta - Ephemeroptera & 64 & 941 & 315 & - & 150 \\
\hline Insecta - Lepidoptera & - & - & - & - & 2 \\
\hline Insecta - Megaloptera & - & - & 2 & 29 & 4 \\
\hline Insecta - Odonata - Anisoptera & - & 5 & 28 & 57 & - \\
\hline Insecta - Odonata - Zygoptera & - & 5 & 4 & - & 7 \\
\hline Insecta - Plecoptera & - & 123 & 70 & - & 77 \\
\hline Insecta - Trichoptera & 389 & 4,483 & 11 & 296 & 819 \\
\hline Isopoda & - & - & - & 817 & - \\
\hline Malacostraca & - & 108 & - & - & - \\
\hline Mollusca - Gastropoda & 48 & 5 & - & 583 & - \\
\hline Mollusca - Pelycypoda & - & - & 20 & 568 & - \\
\hline Nematoda & 85 & 310 & 33 & 430 & 15 \\
\hline Nemertia & - & - & - & 29 & - \\
\hline Oligochaeta & 1,041 & 571 & 855 & 860 & 308 \\
\hline Platyhelminthes - Turbellaria & - & - & 46 & 182 & 9 \\
\hline Porifera & - & - & - & - & 2 \\
\hline Total organisms per square meter substrate & 2,975 & 11,327 & 4,329 & 12,310 & 3,343 \\
\hline Significant taxonomic groups & 11 & 16 & 19 & 18 & 17 \\
\hline
\end{tabular}


Appendix 9. Fish fauna

[g, grams]

\section{MYERS CREEK}

\begin{tabular}{llrc}
\hline \multicolumn{1}{c}{ Scientific name } & \multicolumn{1}{c}{ Common name } & $\begin{array}{r}\text { Total weight } \\
\text { (g) }\end{array}$ & $\begin{array}{c}\text { Number } \\
\text { collected }\end{array}$ \\
\hline Ameiurus natalis & yellow bullhead & 194.4 & 2 \\
Aphredoderus sayanus & pirate perch & 4.2 & 2 \\
Enneacanthus chaetodon & blackbanded sunfish & 8.2 & 4 \\
Esox americanus & redfin pickerel & 10.3 & 2 \\
Etheostoma olmstedi & tessellated darter & 7.7 & 8 \\
Gambusia holbrooki & eastern mosquitofish & .8 & 4 \\
Labidesthes sicculus & brook silverside & 2.1 & 3 \\
Lepomis auritus & redbreast sunfish & 478.8 & 7 \\
Lepomis gulosus & warmouth & 156.8 & 4 \\
Lepomis macrochirus & bluegill & 174.0 & 56 \\
Lepomis marginatus & dollar sunfish & 40.4 & 7 \\
Lepomis punctatus & spotted sunfish & 119.5 & 6 \\
Minytrema melanops & spotted sucker & $6,400.0$ & 7 \\
Notropis petersoni & coastal shiner & 6.1 & 10 \\
Perca flavescens & yellow perch & 610.3 & 17 \\
\hline
\end{tabular}

\section{CEDAR CREEK}

\begin{tabular}{|c|c|c|c|}
\hline Scientific name & Common name & $\begin{array}{l}\text { Total weight } \\
\text { (g) }\end{array}$ & $\begin{array}{l}\text { Number } \\
\text { collected }\end{array}$ \\
\hline Ameiurus natalis & yellow bullhead & 108.2 & 2 \\
\hline Ameiurus nebulosus & brown bullhead & 29.9 & 2 \\
\hline Enneacanthus chaetodon & blackbanded sunfish & 34.7 & 12 \\
\hline Enneacanthus gloriosus & bluespotted sunfish & 51.4 & 4 \\
\hline Esox niger & chain pickerel & 258.4 & 5 \\
\hline Etheostoma olmstedi & tessellated darter & 2.2 & 1 \\
\hline Gambusia holbrooki & eastern mosquitofish & 4.1 & 9 \\
\hline Labidesthes sicculus & brook silverside & 1.8 & 3 \\
\hline Lepomis auritus & redbreast sunfish & 260.4 & 3 \\
\hline Lepomis gulosus & warmouth & 270.9 & 9 \\
\hline Lepomis macrochirus & bluegill & 22.3 & 4 \\
\hline Lepomis marginatus & dollar sunfish & 213.1 & 8 \\
\hline Lepomis punctatus & spotted sunfish & 94.5 & 3 \\
\hline Lepomis sp. & sunfish species & 22.5 & 14 \\
\hline Micropterus salmoides & largemouth bass & 29.0 & 2 \\
\hline Minytrema melanops & spotted sucker & 845.5 & 3 \\
\hline Notropis cummingsae & dusky shiner & 16.0 & 32 \\
\hline Notropis petersoni & coastal shiner & .5 & 1 \\
\hline Noturus gyrinus & tadpole madtom & 2.6 & 1 \\
\hline Noturus insignis & margined madtom & 79.8 & 13 \\
\hline Noturus leptacanthus & speckled madtom & 4.9 & 1 \\
\hline Perca flavescens & yellow perch & 93.8 & 5 \\
\hline Percina crassa & piedmont darter & 1.6 & 1 \\
\hline Pteronotropis hypselopterus & sailfin shiner & 6 & 15 \\
\hline
\end{tabular}


Appendix 9. Fish fauna-Continued

[g, grams]

\section{CEDAR CREEK NEAR WISE LAKE}

\begin{tabular}{llcc}
\hline \multicolumn{1}{c}{ Scientific name } & \multicolumn{1}{c}{ Common name } & $\begin{array}{c}\text { Total weight } \\
(\mathbf{g})\end{array}$ & $\begin{array}{c}\text { Number } \\
\text { collected }\end{array}$ \\
\hline Amia calva & bowfin & $\mathrm{a}$ & 1 \\
Aphredoderus sayanus & pirate perch & $\mathrm{b}$ & 1 \\
Esox niger & chain pickerel & $\mathrm{b}$ & 1 \\
Etheostoma olmstedi & tessellated darter & 1.0 & 1 \\
Labidesthes sicculus & brook silversides & 1.6 & 1 \\
Lepomis auritus & redbreast sunfish & 961.9 & 9 \\
Lepomis gulosus & warmouth & 319.6 & 5 \\
Lepomis macrochirus & bluegill & 128.4 & 3 \\
Lepomis marginatus & dollar sunfish & $\mathrm{b}$ & 1 \\
Lepomis microlophus & redear sunfish & 730.4 & 9 \\
Micropterus salmoides & largemouth bass & $4,323.4$ & 9 \\
Minytrema melanops & spotted sucker & $2,585.4$ & 6 \\
Notropis petersoni & coastal shiner & 3.0 & 1 \\
Noturus insignis & margined madform & $\mathrm{b}$ & 1 \\
Perca flavescens & yellow perch & 622.4 & 13 \\
Pomoxis nigromaculatis & black crappie & 136.5 & 1 \\
\hline
\end{tabular}

${ }^{\mathrm{a}}$ Fish escaped before it could be weighed.

${ }^{\mathrm{b}}$ No weight data available.

\section{TOMS CREEK}

\begin{tabular}{llrr}
\hline \multicolumn{1}{c}{ Scientific name } & \multicolumn{1}{c}{ Common name } & $\begin{array}{c}\text { Total weight } \\
\text { (g) }\end{array}$ & $\begin{array}{c}\text { Number } \\
\text { collected }\end{array}$ \\
\hline Ameiurus natalis & yellow bullhead & 229.8 & 5 \\
Erimyzon oblongus & creek chubsucker & 14.4 & 1 \\
Esox americanus & redfin pickerel & 282.8 & 10 \\
Esox niger & chain pickerel & 219.5 & 4 \\
Gambusia holbrooki & eastern mosquitofish & 3.7 & 14 \\
Lepomis auritus & redbreast sunfish & 805.0 & 13 \\
Lepomis gulosus & warmouth & 75.3 & 4 \\
Lepomis macrochirus & bluegill & 61.3 & 1 \\
Lepomis marginatus & dollar sunfish & 116.6 & 13 \\
Lepomis punctatus & spotted sunfish & 360.3 & 15 \\
Minytrema melanops & spotted sucker & 800.0 & 1 \\
Notropis cummingsae & dusky shiner & 25.1 & 51 \\
Perca flavescens & yellow perch & 115.3 & 3 \\
Pteronotropis hypselopterus & sailfin shiner & 47.8 & 81 \\
\hline
\end{tabular}


Appendix 10. Fish indices of biotic integrity (IBI)

[\#, number; \%, percent; <, less than; >, greater than; IBI score: 12-28, very poor; 29-40, poor; 41-48, fair; 49-58, good; $>58$ excellent]

\begin{tabular}{|c|c|c|c|c|c|c|c|c|c|c|c|c|c|c|c|}
\hline \multirow[b]{2}{*}{ Metric } & \multicolumn{3}{|c|}{$\begin{array}{l}\text { Congaree River } \\
\text { at Columbia }\end{array}$} & \multicolumn{3}{|c|}{ Myers Creek } & \multicolumn{3}{|c|}{ Cedar Creek } & \multicolumn{3}{|c|}{$\begin{array}{l}\text { Cedar Creek near } \\
\text { Wise Lake }\end{array}$} & \multicolumn{3}{|c|}{ Toms Creek } \\
\hline & $\#$ & $\%$ & Score $^{a}$ & $\#$ & $\%$ & Score ${ }^{a}$ & $\#$ & $\%$ & Score $^{a}$ & $\#$ & $\%$ & Score $^{a}$ & $\#$ & $\%$ & Score $^{\mathrm{a}}$ \\
\hline Native species & 15 & & 3 & 14 & & 3 & 23 & & 5 & 16 & & 5 & 13 & & 3 \\
\hline Open-water species & 7 & & 5 & & & & & & & & & & & & \\
\hline $\begin{array}{l}\text { Benthic insectivorous } \\
\text { species }\end{array}$ & & & & 3 & & 1 & 5 & & 3 & 1 & & 1 & 2 & & 1 \\
\hline Sunfish species & 2 & & 1 & 5 & & 3 & 6 & & 5 & 5 & & 3 & 5 & & 3 \\
\hline Cyprinid species & 2 & & 1 & 1 & & 1 & 3 & & 1 & 1 & & 1 & 3 & & 1 \\
\hline Intolerant species & 2 & & 3 & 3 & & 3 & 4 & & 5 & 3 & & 3 & 0 & & 1 \\
\hline Tolerant individuals & 89 & 94 & 1 & 107 & 78 & 1 & 144 & 94 & 1 & 49 & 82 & 1 & 216 & $\begin{array}{r}10 \\
0\end{array}$ & 1 \\
\hline Omnivorous individuals & 41 & 43 & 3 & 17 & 13 & 5 & 33 & 21 & 3 & 23 & 38 & 3 & 0 & 0 & 5 \\
\hline $\begin{array}{l}\text { Insectivorous or inverti- } \\
\text { vorous individuals }\end{array}$ & 11 & 12 & 1 & 118 & 86 & 5 & 111 & 72 & 5 & 39 & 65 & 5 & 199 & 92 & 5 \\
\hline Piscivorous individuals & 10 & 11 & 5 & 2 & 15 & 3 & 10 & 6 & 5 & 2 & 3 & 3 & 17 & 8 & 5 \\
\hline Hybrid individuals & 0 & 0 & 5 & 0 & 0 & 5 & 14 & 9 & 5 & 0 & 0 & 5 & 0 & 0 & 5 \\
\hline Anomalies & 18 & 19 & 1 & 10 & 7 & 3 & 8 & 5 & 1 & 46 & 77 & 1 & 1 & $<1$ & 5 \\
\hline Total fish & 95 & & 5 & 137 & & 5 & 154 & & 5 & 60 & & 3 & 216 & & 5 \\
\hline Total species & 20 & & & 15 & & & 24 & & & 16 & & & 14 & & \\
\hline IBI score & & & 34 & & & 38 & & & 44 & & & 34 & & & 40 \\
\hline $\begin{array}{r}\text { Water-quality } \\
\text { designation }\end{array}$ & & & Poor & & & Poor & & & Fair & & & Poor $^{b}$ & & & Poor \\
\hline
\end{tabular}

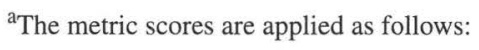

\begin{tabular}{lccr}
\hline \multirow{2}{*}{\multicolumn{1}{c}{ Metric }} & \multicolumn{3}{c}{ Metric score criteria } \\
\cline { 2 - 4 } & $\mathbf{1}$ & $\mathbf{3}$ & $\mathbf{5}$ \\
\hline Native species & $<9$ & $9-15$ & $>15$ \\
Open-water species & $<4$ & $4-6$ & $>6$ \\
Benthic insectivorous species & $<4$ & $4-6$ & $>6$ \\
Sunfish species & $<4$ & $4-5$ & $>5$ \\
Cyprinid species & $<4$ & $4-6$ & $>6$ \\
Intolerant species & $<2$ & $2-3$ & $>3$ \\
Tolerant individuals & $>45 \%$ & $20-45 \%$ & $<20 \%$ \\
Omnivorous individuals & $>45 \%$ & $20-45 \%$ & $<20 \%$ \\
Insectivorous or invertivorous individuals & $<25 \%$ & $25-50 \%$ & $>50 \%$ \\
Piscivorous individuals & $<2$ & $2-5$ & $>5$ \\
Hybrid individuals & $>1$ & 1 & 0 \\
Anomalies & $>5$ & $2-5$ & $<2$ \\
\hline
\end{tabular}

${ }^{\mathrm{b}}$ The designation "poor" for this stream should be viewed with caution. Fish collection was hampered by low conductivity, deep bed sediment, dark water, and unsafe conditions for shocking. Seining was not feasible because of numerous woody snags. Four additional species were collected in subsequent trips but are not included in the shocking data because they were not collected as part of the standard procedure. They are included in the species list and are added to the IBI after the fish collected in the standard run. 
Appendix 11. Tissue pesticides

[nd, not detected; concentrations in micrograms per kilogram]

\begin{tabular}{|c|c|c|c|c|c|c|c|c|}
\hline \multirow{3}{*}{ Analyte } & $\begin{array}{c}\text { Congaree } \\
\text { River at } \\
\text { Columbia } \\
\text { (Left bank) }\end{array}$ & $\begin{array}{c}\text { Congaree } \\
\text { River at } \\
\text { Columbia } \\
\text { (Right bank) }\end{array}$ & $\begin{array}{c}\text { Congaree } \\
\text { River at } \\
\text { Columbia }\end{array}$ & $\begin{array}{l}\text { Myers } \\
\text { Creek }\end{array}$ & $\begin{array}{l}\text { Cedar } \\
\text { Creek }\end{array}$ & $\begin{array}{l}\text { Cedar } \\
\text { Creek }\end{array}$ & $\begin{array}{l}\text { Toms } \\
\text { Creek }\end{array}$ & $\begin{array}{c}\text { Congaree } \\
\text { River at } \\
\text { Highway } 601\end{array}$ \\
\hline & \multicolumn{8}{|c|}{ Test organism } \\
\hline & $\begin{array}{l}\text { Asiatic } \\
\text { clam }\end{array}$ & $\begin{array}{c}\text { Asiatic } \\
\text { clam }\end{array}$ & $\begin{array}{l}\text { Common } \\
\text { carp }\end{array}$ & $\begin{array}{c}\text { Red- } \\
\text { breast } \\
\text { sunfish }\end{array}$ & $\begin{array}{l}\text { Native } \\
\text { clam } \\
\text { (Elliptio } \\
\text { sp.) }\end{array}$ & $\begin{array}{l}\text { Redbreast } \\
\text { sunfish }\end{array}$ & $\begin{array}{l}\text { Red- } \\
\text { breast } \\
\text { sunfish }\end{array}$ & $\begin{array}{l}\text { Asiatic } \\
\text { clam }\end{array}$ \\
\hline Aldrin & nd & nd & nd & nd & nd & nd & nd & nd \\
\hline Dacthal & nd & nd & nd & nd & nd & nd & nd & nd \\
\hline alpha-HCH & nd & nd & nd & nd & nd & nd & nd & nd \\
\hline Endrin & nd & nd & nd & nd & nd & nd & nd & nd \\
\hline gamma-HCH (Lindane) & nd & nd & nd & nd & nd & nd & nd & nd \\
\hline Heptachlor & nd & nd & nd & nd & nd & nd & nd & nd \\
\hline Mirex & nd & nd & nd & nd & nd & nd & nd & nd \\
\hline$o, p^{\prime}-\mathrm{DDE}$ & nd & nd & nd & nd & nd & nd & nd & nd \\
\hline$o, p^{\prime}-\mathrm{DDD}$ & nd & nd & nd & nd & nd & nd & nd & nd \\
\hline$o, p^{\prime}$-DDT & nd & nd & nd & nd & nd & nd & nd & nd \\
\hline$o, p^{\prime}$-Methoxychlor & nd & nd & nd & nd & nd & nd & nd & nd \\
\hline Oxychlordane & nd & nd & nd & nd & nd & nd & nd & nd \\
\hline$p, p^{\prime}$-DDT & nd & nd & nd & nd & nd & nd & nd & nd \\
\hline$p, p^{\prime}$-Methoxychlor & nd & nd & nd & nd & nd & nd & nd & nd \\
\hline Pentachloroanisole & nd & nd & nd & nd & nd & nd & nd & nd \\
\hline Total PCB & nd & nd & nd & nd & nd & nd & nd & nd \\
\hline Toxaphene & nd & nd & nd & nd & nd & nd & nd & nd \\
\hline beta-BHC & nd & nd & nd & nd & nd & nd & nd & nd \\
\hline cis-Nonachlor & nd & nd & 6.7 & nd & nd & nd & nd & nd \\
\hline Dieldrin & nd & nd & 7.6 & nd & nd & nd & nd & nd \\
\hline Heptachlor epoxide & nd & nd & nd & nd & nd & nd & nd & nd \\
\hline$p, p^{\prime}-\mathrm{DDD}$ & nd & nd & 27 & nd & nd & nd & nd & nd \\
\hline trans-Chlordane & nd & nd & 10 & nd & nd & nd & nd & nd \\
\hline trans-Nonachlor & nd & nd & 21 & nd & nd & nd & nd & nd \\
\hline cis-Chlordane & nd & 5.2 & 15 & nd & nd & nd & nd & nd \\
\hline$p, p^{\prime}-\mathrm{DDE}$ & 16 & 16 & 180 & 5.1 & nd & 16 & 10 & 6.2 \\
\hline
\end{tabular}


Appendix 12. Elements in carp liver tissue from the Congareee River at Columbia

[Concentrations in micrograms per gram, dry weight]

\begin{tabular}{lc}
\hline \multicolumn{1}{c}{ Element } & Concentration \\
\hline Aluminum & 13.8 \\
Antimony & 0 \\
Arsenic & .29 \\
Barium & .144 \\
Beryllium & 0 \\
Boron & 0 \\
Cadmium & 10.1 \\
Chromium & 0 \\
Cobalt & .18 \\
Copper & 110.61 \\
Iron & 1,430 \\
Lead & .23 \\
Manganese & 3.72 \\
Mercury & .31 \\
Molybdenum & .87 \\
Nickel & 0 \\
Selenium & 5.23 \\
Silver & .86 \\
Strontium & .767 \\
Uranium & 0 \\
Vanadium & 1.92 \\
Zinc & 657 \\
\hline
\end{tabular}


Appendix 13. Sediment organochlorine pesticides [nd, not detected; concentrations in micrograms per kilogram]

\begin{tabular}{|c|c|c|c|c|c|c|c|}
\hline Analyte & $\begin{array}{c}\text { Congaree } \\
\text { River at } \\
\text { Columbia } \\
\text { (Left bank) }\end{array}$ & $\begin{array}{c}\text { Congaree } \\
\text { River at } \\
\text { Columbia } \\
\text { (Right bank) }\end{array}$ & $\begin{array}{l}\text { Myers } \\
\text { Creek }\end{array}$ & $\begin{array}{l}\text { Cedar } \\
\text { Creek }\end{array}$ & $\begin{array}{c}\text { Cedar } \\
\text { Creek } \\
\text { near Wise } \\
\text { Lake }\end{array}$ & $\begin{array}{l}\text { Toms } \\
\text { Creek }\end{array}$ & $\begin{array}{c}\text { Congaree } \\
\text { River at } \\
\text { Highway } 601\end{array}$ \\
\hline Aldrin & nd & nd & nd & nd & nd & nd & nd \\
\hline alpha-HCH & nd & nd & nd & nd & nd & nd & nd \\
\hline beta-HCH & nd & nd & nd & nd & nd & nd & nd \\
\hline Chlorneb & nd & nd & nd & nd & nd & nd & nd \\
\hline cis-Chlordane & nd & 0.64 & nd & nd & nd & nd & nd \\
\hline cis-Nonachlor & nd & nd & nd & nd & nd & nd & nd \\
\hline cis-Permethrin & nd & nd & nd & nd & nd & nd & nd \\
\hline DCPA (Dacthal) & nd & nd & nd & nd & nd & nd & nd \\
\hline Dieldrin & nd & .51 & nd & nd & nd & nd & nd \\
\hline Endosulfan & nd & nd & nd & nd & nd & nd & nd \\
\hline Endrin & nd & nd & nd & nd & nd & nd & nd \\
\hline gamma-HCH (Lindane) & nd & nd & nd & nd & nd & nd & nd \\
\hline Heptachlor & nd & nd & nd & nd & nd & nd & nd \\
\hline Heptachlor epoxide & nd & nd & nd & nd & nd & nd & nd \\
\hline Isodrin & nd & nd & nd & nd & nd & nd & nd \\
\hline Mirex & nd & nd & 1.2 & nd & nd & nd & nd \\
\hline$o, p^{\prime}-\mathrm{DDE}$ & nd & nd & nd & nd & nd & nd & nd \\
\hline$o, p^{\prime}$-DDD & nd & 2.7 & nd & nd & nd & nd & nd \\
\hline$o, p^{\prime}-\mathrm{DDT}$ & 1.5 & nd & nd & nd & nd & nd & nd \\
\hline$o, p^{\prime}$-Methoxychlor & nd & nd & nd & nd & nd & nd & nd \\
\hline Oxychlordane & nd & nd & nd & nd & nd & nd & nd \\
\hline$p, p^{\prime}-\mathrm{DDD}$ & 1.6 & 2.4 & 5.0 & nd & nd & 1.9 & nd \\
\hline$p, p^{\prime}-\mathrm{DDE}$ & 3.7 & 1.2 & 9.7 & 0.17 & 4.2 & 3.2 & 3.8 \\
\hline$p, p^{\prime} \mathrm{DDT}$ & 2.5 & 2.1 & nd & nd & nd & nd & nd \\
\hline$p, p^{\prime}$-Methoxychlor & nd & nd & nd & nd & nd & nd & nd \\
\hline Pentachloroanisole & nd & nd & nd & nd & nd & nd & nd \\
\hline Total PCB & nd & nd & nd & nd & nd & nd & nd \\
\hline Toxaphene & nd & nd & nd & nd & nd & nd & nd \\
\hline trans-Chlordane & nd & .62 & nd & nd & nd & nd & nd \\
\hline trans-Nonachlor & nd & .47 & nd & nd & nd & nd & nd \\
\hline trans-Permethrin & nd & nd & nd & nd & nd & nd & nd \\
\hline Sum & 9.3 & 10.64 & 15.9 & 0.17 & 4.2 & 5.1 & 3.8 \\
\hline
\end{tabular}


Appendix 14. Sediment non-pesticide organic compounds [nd, not detected; concentrations in micrograms per kilogram unless otherwise indicated]

\begin{tabular}{|c|c|c|c|c|c|c|c|}
\hline Analyte & $\begin{array}{c}\text { Congaree } \\
\text { River at } \\
\text { Columbia } \\
\text { (Left bank) }\end{array}$ & $\begin{array}{c}\text { Congaree } \\
\text { River at } \\
\text { Columbia } \\
\text { (Right bank) }\end{array}$ & $\begin{array}{l}\text { Myers } \\
\text { Creek }\end{array}$ & $\begin{array}{l}\text { Cedar } \\
\text { Creek }\end{array}$ & $\begin{array}{c}\text { Cedar } \\
\text { Creek near } \\
\text { Wise Lake }\end{array}$ & $\begin{array}{l}\text { Toms } \\
\text { Creek }\end{array}$ & $\begin{array}{c}\text { Congaree } \\
\text { River at } \\
\text { Highway } 601\end{array}$ \\
\hline 1-Methyl-9H-fluorene & nd & 31 & nd & nd & nd & nd & 19 \\
\hline 1,2-Dimethylnapthalene & 8 & 12 & nd & nd & nd & nd & 6 \\
\hline 1,2,4-Trichlorobenzene & nd & nd & nd & nd & nd & nd & nd \\
\hline 1,6-Dimethylnapthalene & 20 & 29 & nd & nd & 23 & 16 & 6 \\
\hline 1-Methylphenanthrene & 27 & 110 & 41 & nd & 27 & 15 & 37 \\
\hline 1-Methylpyrene & 41 & 120 & nd & nd & nd & nd & 49 \\
\hline 2,2-Biquinoline & nd & nd & nd & nd & nd & nd & nd \\
\hline 2,3,6-Trimethylnapthalene & 12 & 20 & nd & nd & nd & nd & 17 \\
\hline 2,4-Dinitrotoluene & nd & nd & nd & nd & nd & nd & nd \\
\hline 2,6-Dimethylnapthalene & 17 & 33 & 44 & nd & 36 & 27 & 22 \\
\hline 2,6-Dinitrotoluene & nd & nd & nd & nd & nd & nd & nd \\
\hline 2-Chloronaphthalene & nd & nd & nd & nd & nd & nd & nd \\
\hline 2-Chlorophenol & nd & nd & nd & nd & nd & nd & nd \\
\hline 2-Ethylnaphthalene & nd & nd & nd & nd & nd & nd & nd \\
\hline 2-Methylanthracene & 31 & 81 & nd & nd & nd & nd & 30 \\
\hline 4-Bromophenylphenylether & nd & nd & nd & nd & nd & nd & nd \\
\hline 4-Chlorophenyl phenyl ether & nd & nd & nd & nd & nd & nd & nd \\
\hline $4 \mathrm{H}$-cyclopenta $(d, e, f)$ phenanthrene & 29 & 110 & 53 & nd & 5 & 11 & 35 \\
\hline 9H-Fluorene & 18 & 33 & nd & nd & nd & nd & 13 \\
\hline Acenaphthene & 14 & 37 & nd & nd & nd & nd & 7 \\
\hline Acenaphthylene & 25 & 95 & 21 & nd & nd & 13 & 33 \\
\hline Acridine & 40 & 29 & nd & nd & nd & nd & 9 \\
\hline Anthracene & 28 & 140 & nd & 26 & nd & 12 & 27 \\
\hline Anthroquinone & 69 & 52 & nd & nd & nd & nd & 27 \\
\hline Azobenzene & nd & nd & nd & nd & nd & nd & nd \\
\hline Benzene, p-Dichloro & 12 & 12 & nd & nd & nd & nd & nd \\
\hline $\operatorname{Benzo}(a)$ anthracene & 150 & 370 & 120 & 35 & 52 & 42 & 120 \\
\hline $\operatorname{Benzo}(a)$ pyrene & 210 & 440 & 570 & nd & nd & nd & 140 \\
\hline $\operatorname{Benzo}(b)$ fluoranthene & 230 & 350 & 140 & nd & 21 & 25 & 140 \\
\hline $\operatorname{Benzo}(c)$ quinoline & nd & nd & nd & nd & nd & nd & nd \\
\hline $\operatorname{Benzo}(g, h, i)$ perylene & 97 & 140 & nd & nd & nd & nd & 95 \\
\hline Benzo $(k)$ fluoranthene & 150 & 240 & 98 & nd & 15 & 31 & 80 \\
\hline bis(2-Chloroethoxy) methane & nd & nd & nd & nd & nd & nd & nd \\
\hline bis(2-Ethylhexyl) phthalate & 1,900 & 200 & 260 & 60 & nd & 93 & 220 \\
\hline Butylbenzyl phthalate & 42 & 45 & nd & 47 & 51 & nd & 87 \\
\hline C8-Alkylphenols & nd & nd & nd & nd & nd & nd & nd \\
\hline Carbazole & 46 & 25 & nd & nd & nd & nd & 11 \\
\hline Carbon, total (g/kg) & 7.2 & 19 & nd & 5.7 & nd & nd & nd \\
\hline Carbon, inorganic (g/kg) & 0.5 & 0.1 & nd & nd & nd & nd & nd \\
\hline Carbon, organic $(\mathrm{g} / \mathrm{kg})$ & 6.7 & 19 & nd & 5.7 & nd & nd & nd \\
\hline Chrysene & 210 & 340 & 70 & 25 & 48 & 56 & 120 \\
\hline Di- $n$-butyl phthalate & 56 & 48 & 160 & 76 & 85 & 49 & 76 \\
\hline Di-n-octyl phthalate & 45 & 43 & nd & nd & nd & 39 & 98 \\
\hline $\operatorname{Dibenzo}(a, h)$ anthracene & 59 & 79 & nd & nd & nd & nd & 69 \\
\hline
\end{tabular}


Appendix 14. Sediment non-pesticide organic compounds-Continued [nd, not detected; concentrations in micrograms per kilogram unless otherwise indicated]

\begin{tabular}{|c|c|c|c|c|c|c|c|}
\hline Analyte & $\begin{array}{c}\text { Congaree } \\
\text { River at } \\
\text { Columbia } \\
\text { (Left bank) }\end{array}$ & $\begin{array}{c}\text { Congaree } \\
\text { River at } \\
\text { Columbia } \\
\text { (Right bank) }\end{array}$ & $\begin{array}{l}\text { Myers } \\
\text { Creek }\end{array}$ & $\begin{array}{l}\text { Cedar } \\
\text { Creek }\end{array}$ & $\begin{array}{c}\text { Cedar } \\
\text { Creek near } \\
\text { Wise Lake }\end{array}$ & $\begin{array}{l}\text { Toms } \\
\text { Creek }\end{array}$ & $\begin{array}{c}\text { Congaree } \\
\text { River at } \\
\text { Highway } 601\end{array}$ \\
\hline Dibenzothiophene & 16 & 50 & 19 & nd & nd & nd & 14 \\
\hline Diethyl phthalate & 25 & 24 & 47 & 29 & nd & nd & 20 \\
\hline Dimethyl phthalate & 14 & 11 & nd & 21 & 51 & nd & nd \\
\hline Fluoranthene & 330 & 530 & 340 & 39 & 55 & 96 & 160 \\
\hline Hexachlorobenzene & nd & nd & nd & nd & nd & nd & nd \\
\hline Indeno(1,2,3-cd)pyrene & 230 & 310 & nd & nd & nd & nd & 66 \\
\hline Isophorone & nd & nd & nd & nd & nd & nd & nd \\
\hline Isoquinoline & 12 & 13 & nd & nd & nd & nd & nd \\
\hline N-Nitroso-diphenylamine & nd & nd & nd & nd & 6 & nd & nd \\
\hline N-Nitrosodi-n-propylamine & nd & nd & nd & nd & nd & nd & nd \\
\hline Naphthalene & 22 & 48 & nd & nd & nd & nd & 17 \\
\hline Nitrobenzene & nd & nd & nd & nd & nd & nd & nd \\
\hline$p$-Cresol & 14 & 8 & 260 & 44 & nd & nd & 96 \\
\hline Pentachloronitrobenzene & nd & nd & nd & nd & nd & nd & nd \\
\hline Phenanthrene & 120 & 320 & 130 & 15 & 50 & 47 & 67 \\
\hline Phenanthridine & 23 & 21 & nd & nd & nd & nd & nd \\
\hline Phenol & 8 & 7 & 54 & 31 & nd & nd & 19 \\
\hline Pyrene & 250 & 660 & 200 & 36 & nd & 71 & 200 \\
\hline Quinoline & nd & nd & nd & nd & nd & nd & nd \\
\hline Sum $^{\mathrm{a}}$ & $4,664.4$ & $5,304.1$ & 2,580 & 495.4 & 497 & 643 & 2,110 \\
\hline
\end{tabular}

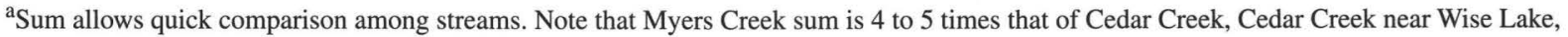
and Toms Creek. 
Appendix 15. Sediment trace elements

[As reported by laboratory, unadjusted for less than 63 micrometer fraction; concentrations in micrograms per gram; nd, not detected]

\begin{tabular}{|c|c|c|c|c|c|c|c|}
\hline Element & $\begin{array}{c}\text { Congaree } \\
\text { River at } \\
\text { Columbia } \\
\text { (Left bank) }\end{array}$ & $\begin{array}{c}\text { Congaree } \\
\text { River at } \\
\text { Columbia } \\
\text { (Right bank) }\end{array}$ & $\begin{array}{l}\text { Myers } \\
\text { Creek }\end{array}$ & $\begin{array}{l}\text { Cedar } \\
\text { Creek }\end{array}$ & $\begin{array}{c}\text { Cedar } \\
\text { Creek near } \\
\text { Wise Lake }\end{array}$ & $\begin{array}{l}\text { Toms } \\
\text { Creek }\end{array}$ & $\begin{array}{c}\text { Congaree } \\
\text { River at } \\
\text { Highway } 601\end{array}$ \\
\hline Antimony & 0.8 & 0.7 & 0.5 & 0.3 & 0.4 & 0.5 & 0.6 \\
\hline Arsenic & 5.7 & 5.7 & 3.1 & 3.5 & 3.6 & 6.6 & 5.4 \\
\hline Barium & 620 & 670 & 460 & 360 & 560 & 320 & 650 \\
\hline Beryllium & 2 & 3 & 2 & 2 & 3 & 2 & 3 \\
\hline Cadmium & .4 & .3 & .6 & .3 & .5 & .4 & .3 \\
\hline Cerium & 120 & 160 & 81 & 140 & 100 & 96 & 130 \\
\hline Chromium & 74 & 85 & 70 & 70 & 92 & 68 & 92 \\
\hline Cobalt & 18 & 22 & 43 & 20 & 32 & 33 & 24 \\
\hline Copper & 46 & 50 & 18 & 20 & 37 & 13 & 39 \\
\hline Europium & nd & nd & nd & nd & nd & nd & nd \\
\hline Gallium & 23 & 27 & 23 & 21 & 29 & 17 & 27 \\
\hline Gold & nd & nd & nd & nd & nd & nd & nd \\
\hline Holmium & nd & nd & nd & nd & nd & nd & nd \\
\hline Lanthanum & 62 & 80 & 40 & 70 & 54 & 44 & 70 \\
\hline Lead & 68 & 36 & 76 & 49 & 54 & 50 & 55 \\
\hline Lithium & 30 & 40 & 30 & 30 & 50 & 20 & 40 \\
\hline Manganese & 3,100 & 1,100 & 1,800 & 580 & 890 & 1,900 & 1,300 \\
\hline Mercury & .1 & .08 & .16 & .11 & .10 & .12 & .08 \\
\hline Molybdenum & 2 & nd & nd & nd & nd & nd & nd \\
\hline Neodymium & 49 & 65 & 31 & 54 & 42 & 35 & 58 \\
\hline Nickel & 28 & 35 & 27 & 22 & 40 & 20 & 35 \\
\hline Niobium & 18 & 21 & 26 & 19 & 27 & 21 & 24 \\
\hline Scandium & 16 & 18 & 10 & 10 & 17 & 9 & 19 \\
\hline Selenium & .9 & .8 & .9 & 1.1 & .7 & .9 & .7 \\
\hline Silver & .3 & .2 & .2 & .2 & .2 & .2 & .4 \\
\hline Strontium & 140 & 160 & 58 & 56 & 93 & 46 & 150 \\
\hline Sulfur & .06 & nd & .18 & .13 & .11 & .16 & nd \\
\hline Thorium & 21 & 22 & 16 & 34 & 14 & 17 & 16 \\
\hline Uranium & 6.6 & 7.3 & 4.95 & 11.4 & 5.66 & 7.63 & 7.39 \\
\hline Vanadium & 110 & 130 & 90 & 97 & 120 & 75 & 130 \\
\hline Ytterbium & 3 & 3 & 1 & 2 & 2 & 2 & 3 \\
\hline Yttrium & 28 & 30 & 22 & 19 & 29 & 25 & 36 \\
\hline Zinc & 130 & 110 & 110 & 59 & 140 & 89 & 110 \\
\hline
\end{tabular}


Appendix 16. Sediment major elements [Concentrations in percent]

\begin{tabular}{|c|c|c|c|c|c|c|c|}
\hline Element & $\begin{array}{l}\text { Congaree River } \\
\text { at Columbia } \\
\text { (Left bank) }\end{array}$ & $\begin{array}{l}\text { Congaree River } \\
\text { at Columbia } \\
\text { (Right bank) }\end{array}$ & $\begin{array}{l}\text { Myers } \\
\text { Creek }\end{array}$ & $\begin{array}{l}\text { Cedar } \\
\text { Creek }\end{array}$ & $\begin{array}{c}\text { Cedar } \\
\text { Creek near } \\
\text { Wise Lake } \\
\end{array}$ & $\begin{array}{l}\text { Toms } \\
\text { Creek }\end{array}$ & $\begin{array}{l}\text { Congaree River } \\
\text { at Highway } 601\end{array}$ \\
\hline Aluminum & 9.1 & 11 & 8.1 & 8.7 & 12 & 6.7 & 11 \\
\hline Calcium & .57 & .59 & .17 & .1 & .23 & .12 & .54 \\
\hline Inorganic carbon & 2.53 & 2.07 & .02 & .03 & .01 & .03 & .02 \\
\hline Iron & 4.7 & 5 & 2.4 & 3.2 & 4 & 3.1 & 5.2 \\
\hline Magnesium & .43 & .47 & .17 & .14 & .44 & .13 & .49 \\
\hline Organic carbon & .03 & .03 & 11.2 & 6.81 & 6.7 & 10.1 & 1.86 \\
\hline Phosphorus & .12 & .12 & .12 & .1 & .13 & .1 & .13 \\
\hline Potassium & 1.4 & 1.5 & .61 & .7 & 1.1 & .42 & 1.5 \\
\hline Sodium & .47 & .46 & .07 & .09 & .2 & .05 & .5 \\
\hline Titanium & .66 & .79 & .73 & 69 & .86 & .64 & .79 \\
\hline $\begin{array}{l}\text { Organic and inorganic } \\
\text { carbon }\end{array}$ & 2.56 & 2.04 & 11.2 & 6.84 & 6.71 & 10.1 & 1.88 \\
\hline
\end{tabular}





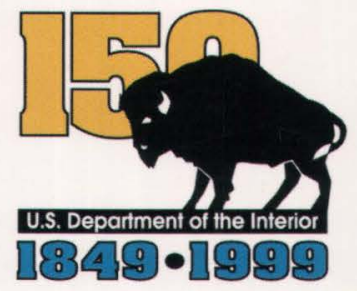

(1) Printed on recycled paper 